\title{
THE DHARMAPUTRIKĀ SAMHITĀ \\ PRELIMINARY NOTES ON AN EARLY TEXT ON YOGA
}

\begin{abstract}
This essay aims to present the current state of research on the Dharmaputrika Samihitā, an ancient text on yoga which describes, with an exceptional depth of detail and a high level of bodily technicality, internal yogic practices. The study of the Dharmaputrikā Saṃhitā was initiated as part of the ERC-funded AyurYog project, which was led by Dagmar Wujastyk (2015-2020), whose central aim was to examine the link between yoga and classical Indian medicine, two distinct fields of knowledge in the Sanskrit tradition. Not only does chapter Ten (called yogacikitsā) of the Dharmaputrikā Saṃhitā describe "therapy in the context of yoga practice," but it also appears to integrate within its discourse the practice's physical and mental effects on the body at each stage of the yoga process, thus reflecting an empirical knowledge of physiology. This essay introduces the dating, authorship, textual history, and reception of the text. It provides preliminary research on parallel passages in other works, and proposes that the Dharmaputrikā Saṃhitā is a textual testimony of ancient yoga practices referred to as the "yoga of Hiranyagarbha." On the basis of the critical edition, which is yet to be published, it offers the reader an annotated and detailed summary of the work's content, along with various discussions of important questions raised by broader considerations on the history of ancient yoga.
\end{abstract}




\section{JOURNAL OF \\ YOGA STUDIES}

$2020 \cdot$ Volume 3

\section{Introduction}

This essay is the first academic study of the Dharmaputrika Samphitā (DhPS), which is generally (and henceforth in this paper) referred to as the Dharmaputrika.$^{1}$ The Dharmaputrika is an early work on yoga ${ }^{2}$ that has been transmitted to us as part of the "Śivadharma corpus," a collection of eight texts preserved in several eleventh- and twelfth-century Nepalese palm-leaf manuscripts. ${ }^{3}$ Typically the last text in this collection, ${ }^{4}$ it comprises about 350 ślokas organised into sixteen chapters. In contrast to the teachings on yoga found in Tantric and Purānic texts, that are always positioned as a subdivision of a larger textual ensemble, the Dharmaputrika is a closed text which does not presuppose or claim dependence on or connexion to any wider authoritative text. It deals exclusively with a psycho-physiological method of exiting the body through respiratory techniques and disciplines of renouncing desires in order to achieve three goals: supernatural powers, the ability to move from one's own body into another, and liberation. Internal practices are described with an exceptional depth of detail and a high level of bodily technicality which presupposes a longstanding tradition of experimentation and systematization.

The first part of this essay consists of preliminary notes on the authorship, dating, and reception of the Dharmaputrikā. In the second part, a detailed summary of this hitherto unknown text is given for the first time. The structure being complex, a synoptic table of the contents of the sixteen chapters is annexed. This presentation introduces material that will be further elaborated in the critical edition and annotated translation currently being prepared. 5 At this stage, four Nepalese manuscripts have been consulted, as well as an apograph preserved at the Wellcome Library and the Nepalese

\footnotetext{
1 On the meaning of "Dharmaputrikā," see note 29.

2 I use italics for the Sanskrit word yoga in order to clearly distinguish it from "yoga" as the term is employed and understood nowadays.

3 These are: the Śivadharmaśāstra, the Śivadharmottara, the Śivadharmasamgraha, the Umāmaheśvarasaṃvāda, the Uttarottaramahāsaṃvāda, the Śivopanișad, and the Vṛ̦asārasaṃraha.

${ }^{4}$ A list of the Nepalese multiple-text manuscripts of the Śivadharma corpus is given in De Simini 2016a (Appendix I). The Dharmaputrikā is replaced by a text called Lalitavistara in a single, multiple-text manuscript dated from the eleventh century (on the Lalitavistara, see De Simini and Mirnig, 2017).

${ }^{5}$ The critical edition of the Dharmaputrikā is currently being carried out in collaboration with Philipp A. Maas and Anil Kumar Acharya (forthcoming 2022).
} 


\section{JOURNAL OF

edition of the "Śivadharma corpus" by Yogin Naraharinātha in 1998.6 As for the manuscripts consulted so far, the general arrangement of the Dharmaputrika into sixteen chapters is consistent among the witnesses consulted for this article and the textual variants are limited. The textual parallels mentioned in this introduction and the detailed summary result from preliminary research and do not claim to be exhaustive. They will be systematically presented in the prolegomena to the critical edition of the text.

The Dharmaputrikā is an instructional yoga manual devoid of scholasticism and philosophical speculation. Its teachings consist of a body of interdependent and progressive practices methodically distributed into its sixteen chapters:

Chapter One: "Section on the instrumental principles," sādhanaprakaranam (74 ślokas)

Chapter Two: "Section on postures," āsanaprakaranam (17 ślokas)

Chapter Three: "Section on the succession of fixations," dhāranāvamśaprakaranam (11 ślokas)

Chapter Four: "Section on the path of meditation," dhyānamārgaprakaranam (88 ślokas)

Chapter Five: "Subtle obstacles," sūkșmāntarāyaḥ (5 ślokas)

Chapter Six: "Very subtle obstacles," mahāsūkșmāntarāyaḥ (28 ślokas)

Chapter Seven: "Obstacles through negligence," pramādajāntarāyaḥ (8 ślokas)

Chapter Eight: "Obstacles such as intuitive knowledge, etc.," prātibhādyantarāyaḥ (6 ślokas)

Chapter Nine: "Conquest," jayaḥ (19 ślokas)

Chapter Ten: "Medical treatment," cikitsā (24 ślokas)

Chapter Eleven: “Transient signs," calalingaḥ (10 ślokas)

Chapter Twelve: "Lasting signs," dhruvalingaḥ (4 ślokas)

Chapter Thirteen: "Means of increasing," vrddhyupāyah (6 ślokas)

\footnotetext{
${ }^{6}$ Manuscripts: MS.SL.57, Paris, Collège de France (Collection Sylvain Lévi) (circa eleventh century). National Archives, Kathmandu, 65843, palm-leaf, NS 290 (circa 1170). University Library, Cambridge, MS Add.1645, palmleaf, dated 259 Nepāla (1139 CE). National Archives, Kathmandu, 65922, 803 (circa 1682-83).

Apograph: Paper manuscript, apograph of a Nepalese multiple-text manuscript. The manuscript copies in the Durbar Library of Kathmandu were made by Bauddhasevita Vajrācārya in the years 1912 and 1913 (Dominik Wujastyk, personal communication). Description of the apograph is given in Dominik Wujastyk 1985, vol. 1.

Edition: Yogin Naraharinātha (ed.). Śivadharma Paśupatinam Śivadharmamahāśāstram Paśupatināthadarśanam. Kathmandu 1998 (samvat 2055).
} 


\section{JOURNAL OF \\ YOGA STUDIES}

$2020 \cdot$ Volume 3

Chapter Fourteen: "Loss," vināśạ̣ (3 ślokas)

Chapter Fifteen: "Recovery,” pratyānayanam (12 ślokas)

Chapter Sixteen: "Means of success," siddhyupāyah (27 ślokas)

The first four chapters are collectively referred to as yogaprakaranam, "Section on yoga." They successively describe eight instrumental principles (sädhanaprakaranam), the formation of eight postures (āsanaprakaranam), the succession of the twenty-eight joints that form a vertical axis in the body and beyond (dhāranāvamśaprakaranam), and the path of meditation (dhyānamārgaprakaranam), that is, the internal process implemented with a view to obtaining one of the three fruits of yoga (i.e., yogic powers, the ability to move from one's own body into another, and liberation). Obstacles arising from the implementation of yoga are discussed in chapters Five to Eight. Their treatment is then detailed in a systematic way in chapters Nine and Ten. Chapters Eleven and Twelve respectively describe the transitional signs (calalinga) and lasting signs (dhruvalinga) of impending success. Chapter Thirteen explains the method of intensification of the yoga practice (vrddhyupaya). Chapters Fourteen and Fifteen respectively explain the causes of the loss (vināśa) of the yoga completion level achieved, and the means to restore (pratyannayana) this completion level once it has been lost. Chapter Sixteen details the means of success (siddhyupāya), namely moral dispositions and cognitions preliminary to the practice of yoga, and the final withdrawal process of manas alone (kevalam).

The practical and didactic nature of this exposition of yoga is evident through its formal features and organization: the sixteen chapters correspond exactly to the sixteen "means of accomplishment" (sädhanopāya) accounting for all the teachings (they are enumerated at the beginning of chapter One); the chapters are long or very short depending on the subject matter; ${ }^{7}$ the first chapter consists of clear definitions organized by subject; there is significant use of classification by numbering, etc., aiming to improve memorization of the teachings. Methodical and relevant internal references, indications of the order of succession of practices and their priority, as well as details on combined practices give access to an understanding of the temporality of the practice (simultaneous, successive, or repeated sequences) and to the difference between prescriptions and definitions and their prioritization. These organizational markers suggest the possibility of an in-depth understanding of the practice.

\footnotetext{
7 The longest chapter comprises 88 ślokas (DhPS 4: dhyānamärgaprakaranam), the shortest of which is only 3 ślokas (DhPS 14: vināśah). A yoga text with the same disparity between chapters in terms of length is the Amrtasiddhi. See Mallinson and Szántó, 2019.
} 


\section{JOURNAL OF \\ YOGA STUDIES}

$2020 \cdot$ Volume 3

The Dharmaputrikā does not give a general definition of yoga as in the Pātañjalayogaśāstra, such as: yogaḥ samādhị̣ (Bhāșya ad Yogasūtra 1.1) or yogaś cittavrttinirodhah (Yogasūtra 1.2). The first significant occurrence of the word yoga is found in the compound yogaprakaranam, "Section on yoga," which designates the first four chapters of the text (sādhanaprakaranam, āsanaprakaranam, dhāraṇāvaṃśaprakaranam, dhyānamārgaprakaranam). This suggests that the first four chapters deal specifically with the process of yoga, while the subsequent chapters are more concerned with complementary practices, such as remedies to the obstacles, signs of success, annihilation and restoration, and intensification. Based on the topics addressed in these four chapters, one understands that yoga is the result of a combination of convergent actions preceded by preparatory practices. The definition of the fixation (dhāraṇa) situates yoga last in the series prānāyāma, dhāraṇā, yojanāa, yoga, depending on the length of the breath retention (see detailed summary $\S 1.1 .4$ and the related note), which means yoga is the highest level to result from actions subjected to the increasing duration of breath retention.

Yoga leads to supernatural powers, or the ability to move from one's own body into another, or liberation, all three of which involve abandoning the existing body (see $\S 4.4$ ). The going-out from the body is explicit in the description of the "upwards exhalation" (udrecanī), a breathing exercise aimed at reaching a position beyond the "material" body, and the description of the "ascent up to dissolution" (pralayotkrānti), corresponding to the process of dying ( $k \bar{a} l a)$ (see detailed summary $\S 4.3 .4$ and 4.3.5). But yoga here never strictly designates union with the divine: this is evident when the term yoga is used to describe the transfer of the soul to another body, for example (see $\S 4.4 .2)$. Rather, yoga has the meaning of "conjunction," which does not preclude the existence of the immersion of the individual soul (bindu, jiva, àtman) into a supreme principle. From a certain point of view, yoga can be seen as a "Sterbetechnik."

The physical and mental effects of the yoga practice are taken into account at each stage of the yoga process, reflecting an empirical knowledge of physiology. Not only is knowledge of the theory of classical medicine evident in the use of medical terminology (technical names of diseases, mention of the three humours and their location in the body, reference to a vaidyaśāstra, etc.) but, most importantly, several passages demonstrate the existence of medical practices specifically adapted to yogins. ${ }^{9}$ This

\footnotetext{
8 See Schreiner, 1988.

9 Chapter Ten, named "Medical treatment" (cikitsā), demonstrates knowledge of classical medicine (see detailed summary). See also Barois (forthcoming 2021): "The Medical Practices of yogins in early Medieval India: The testimony of the Dharmaputrikā Saṃitā." History of Science in South Asia, hssa-journal.org.
} 


\section{JOURNAL OF \\ YOGA STUDIES}

$2020 \cdot$ Volume 3

makes the Dharmaputrika an early testimony to the concern of the yogins with medical knowledge and the integration of both prophylactic and therapeutic treatments during the yoga process.

An in-depth discussion of the theological elements discernible in the purely practical yoga teachings of the Dharmaputrika goes beyond the scope of the present article. Nevertheless, it is possible to introduce a few preliminary notes questioning its Śaiva nature.

Throughout the text, mentions of "Śiva" are rare and occur in a definite context of use: in the subdivision dealing with the six ancillaries (sadanga), the definition of dhyanna indicates that Śiva is the one to be meditated upon (dhyeya) (chapter One, see detailed summary § 1.1.2); in the subdivision on the "three methods of conjunction" (trividho yogah), Sadāsiva is mentioned as the first of a series emanating from the fiery power (tejas) of Paramātman (chapter One, see detailed summary $\S 1.6$ ); in chapter Four (dhyānamärgaprakaraṇam), the drop (bindu), defined as the individual soul (jīva, ātman) and the god (deva), is made up of five entities to be meditated on (pañcadhyeya), namely Prakrti, Purușa, Prabhu, Vidyā, and Śiva: in this context, Śiva is the twenty-eighth tattva (see detailed summary $\$ 4.1$, and note 111); finally, in chapter Sixteen, in the context of an archery metaphor illustrating the ultimate internal practice, Śiva is defined as the target, also equated with the bindu (see detailed summary $\S 4.3 .5$, note 131, and chapter Sixteen).

Mentions of specific mantras are also rare, scantily detailed, and do not explicitly show Śaiva features. First, in chapter Nine, in the context of the conquest of the very subtle obstacle (that is, fear at the time of death), two procedures involving respectively a tensyllable mantra for conquering death (mrtyunjaya) and a mantra with eighty-one words (ekâsítipada) (without the term vyomavyāpin being mentioned) are briefly explained (see detailed summary $\$ 9.2$ and notes 145 and 146). Secondly, in chapter Sixteen, HAMSA as well as an uncertain allusion to angamantras and brahmamantras occur in an obscure verse (see detailed summary and note 165). Apart from these two allusive passages, only the syllable OM is mentioned. To my knowledge, there is no other yoga text that so precisely explains a technique of breath elongation (prānāyāma) and fixation (dhāraña) simultaneously with the practice of OM. However, no identification of the syllable OṂ with Śiva nor any homologisation of its constituent letters is indicated, as is generally the case in Śaiva texts. ${ }^{10}$

\footnotetext{
10 As is the case, for example, in Śivadharmottara 10 (W 121r): japed dhyāyec ca satatam o[ṃ]kāra[ṃ] śivarūpinam | vācyavācakabhāvena mātrātrayavibhāgatah |.
} 


\section{JOURNAL OF \\ YOGA STUDIES}

2020 - Volume 3

In the Dharmaputrika, the only principles which relate specifically to Śaiva theology are a set of three tattvas (tritattva, tattvatraya), namely ātmatattva, vidyātattva, and sivatattva. These three tattvas are briefly detailed in the context of the definition of the fifth discipline, "perception of principles" (tattvadarśana), in chapter One (see detailed summary $\S 1.3$ and note 88 ). These appear to be a key theologem, since they are mentioned at the beginning of the text as prerequisite knowledge. ${ }^{11}$ However, the theological implications of these archaic Śaiva principles are not elaborated: the three tattvas are never homologized with "tranches of the universe," and no initiation, a fortiori involving purification of the three tattvas, is mentioned.

Besides these rare Śaiva elements, mentions of Brahman as conceived of in the Upanișads are found throughout the text. The term paramatman occurs twice in the context of the three methods of conjunction (trividho yogah) (DhPS 1.58 and 1.60, see detailed summary $\S 1.6$ ), and once in the context of the subtle obstacles, in chapter Nine, where a definition of the supreme self (paramätman) as distinct from the empirical self (ātman) is given (see $\S 9.1$ ). Liberation (mokșa) is clearly described as the attainment of the supreme Brahman (param brahma) (DhPS 4.88, see detailed summary $\S 4.4 .3$ ), a mention which is found in the same context in chapter Sixteen. Further, being constantly absorbed in Brahman (brahmapara) is prescribed in chapter Eight, dealing with "Obstacles such as intuitive knowledge, etc." (prātibhādyantarāya) (see detailed summary). It therefore appears that the Dharmaputrikā teaches a method for merging the individual self with the supreme self, where the Saiva features are non-structural and sparsely integrated into a broader conception in which the supreme is conceived as Brahman. The single occurrence of the term istadeva, at the beginning of chapter Two, may indicate that the choice of personal deity is left to the yogin.12 Could the Dharmaputrikā bear witness to psycho-physiological yoga techniques based on the ancient soteriological pattern of the individual soul merging with Brahman which were, as technical teachings, not immediately concerned with the sectarian (Śaiva or Vaiṣnava) orientations?

\footnotetext{
${ }_{11}$ Dharmaputrikā 1.8-9: tasmād evam viditvādau tritattvañ ca yathākramam | dānaśîlādibhiś cittam śodhayitvā viśeșatah | tato yogah prayoktavyas tyaktasangena yoginā | vìtarāgeṇa śāntena śucinā śuddhacetasā | - Goodall (2016: 93) notes that these three tattvas may be very old and specifies that this "originally independent tattvakrama [...] appears in the Sārdhatriśatikālottara $(2.6 \mathrm{c}-7 \mathrm{~b})$, homologized with the three principal sounds of the pranava, but it makes no appearance in the Niśvāsa-corpus until the Guhyasūtra." These three tattvas, considered as the "encompassing tattva" in later Saiddhāntika texts, "appear without a clear account of how they are conceived in a number of early sources." (Goodall, 2016: Tāntrikābhidhānakośa vol. 3, 59, "tattvatraya.")
}

${ }_{12}$ Dharmaputrikā 2.2: ișțadevaṃ namaskrtyopādhyāyam caiva yatnatah | āsthāya prānmukho bhūtvā śucir yogĩ viśeșataḥ | 


\section{JOURNAL OF \\ YOGA STUDIES}

$2020 \cdot$ Volume 3

\section{The authorship of the Dharmaputrikā}

At the beginning and at the end of the Dharmaputrika a speaker informs us, in the first person singular, about its origin and authorship. At the beginning, following two introductory verses, the speaker indicates what I assume to be a mythical transmission of the Dharmaputrikā (DhPS 1.1):

\section{śāstrasyādipraṇetāram sanakaṃ munipungavam | namaskṛtya pravakșyāmi saṃhitāṃ dharmaputrikām |}

After having paid homage to the eminent sage Sanaka, who was the first promulgator of the doctrine, I will teach the Dharmaputrikā Saṃitā.

This succinct opening differs from the dialogical device of the narrative framework characteristic of Āgamic and Purānic literature which systematically ascribes the texts to a divine origin, Śiva, Vișnu, or Brahmā. The formulation is straightforward, and the use of the rare compound adipranetr suggests a personal language as opposed to the epic formulaic style.

In Epic and Purānic literature, Sanaka mostly appears as the first of the four mind-born sons of Brahmā (sanakādi) without being individualized. These mind-born sons are collectively described as yogins devoid of passion (vïtarāga) and selfishness (vimatsara). ${ }^{13}$ The mention of the name "Sanaka" and the other mind-born sons of Brahmā is used for the purpose of conveying the image of the yogin par excellence. But the transmission of a specific yoga teaching is not formally attributed to Sanaka in the early Śaiva or Vaiṣnava texts that I was able to consult, nor in the literature of Hațhayoga. To my knowledge, there is no other case than the Dharmaputrika where Sanaka is the "first promulgator" of a specific yoga text.

In the concluding passage of the Dharmaputrikā, the speaker speaks again in the first person singular. He confirms the fact that Sanaka is the author of the treatise and identifies himself as the son of Dharmaśila and the compiler of the text (DhPS 16.25-26):

$$
\begin{aligned}
& \text { ālokyātyantagūụhārtham śāstraṃ sanakanirmitam | } \\
& \text { vastumātraṃ samādāya dharmaśilasya sūnunā | } \\
& \text { sukhāvabodhā bālānāṃ granthitā saṃhitā mayā | }
\end{aligned}
$$

\footnotetext{
${ }^{13}$ These mentions are common in the Mahābhārata and the Purāṇas. Vijñānabhikṣu also describes the four mindborn sons of Brahmā as possessing a passionless mind in his Yogavārttika ad Pātañjalayogaśāstra 1.37: vītarāgam yat sanakādīnāṃ cittam [...] | (Pātañjalayogadarśanam, 1971: 104). It should be noted, however, that there is an instance where Sanaka, not included in the list of other mind-born sons but cited alone, is described as the best among yogins (sanako yogināṃ varaḥ) in Viṣnudharmāḥ 38.69 (Grünendahl, 1983: 199).
} 


\section{JOURNAL OF \\ YOGA STUDIES}

2020 - Volume 3

nirūpya dātum arhanti doșān tyaktvā manīṣinah |

The saṃhita easily intelligible to novices was composed by me, son of Dharmaśila, after considering the treatise composed by Sanaka, the meaning of which is highly secret, [and] after having grasped the substance [of it]. Having examined [this samhitā] and having freed themselves from their faults, the wise men are worthy of passing [it] down.

The speaker, who calls himself son of Dharmaśila, specifies that the Dharmaputrikā, which he characterizes as a "collection" (samhitā), is a version abridged by him for educational purposes (the word bāla, which qualifies the recipients of the abridged version, means "young boy," "ignorant person," or "beginner") of a śāstra originally promulgated by Sanaka. This statement is congruent with the opening passage, where the Dharmaputrikā is also qualified as a śāstra, which seems to denote a specific text rather than a domain of knowledge. 14 The designation as samhitā at second instance presupposes a reconfiguration of the text. It seems that the composition of the Dharmaputrika, clearly expressed through the past participle granthita, inaugurated a transmission for the sake of a group of novices. The intervention of the son of Dharmaśila is also evident in two prose passages which seem to belong to the original text: one introducing the four sections of yoga (yogaprakaranam) in Dharmaputrika 1.10, the other introducing the four kinds of obstacle at the beginning of chapter Five (see the detailed summary and the synoptic table).

The name "Dharmaśila" is naturally intriguing. Very few men by the name of Dharmaśila have come down to posterity, and mythological or legendary characters by the name of Dharmaśila are rare. In the Mahābhārata, dharmaśila is a recurrent epithet of Yudhisțhira, just like dharmaputra, another epithet which recalls his filiation. In Kathāsaritsāgara IX.51, a secondary character named Dharmaśila, son of a king of the Vidyādharas, Alañkāraśîla, undertakes from an early age an asceticism for Śiva. However, we can reasonably assume that in the Dharmaputrikā the mention of Dharmaśila is not a mythological or legendary reference, because of the use of the first person singular of the speaker and the absence of descriptive elements with laudatory content.

\footnotetext{
${ }^{14}$ This makes the Dharmaputrikā a yogaśāstra. Whether śāstra refers in this case to a text or a domain of knowledge remains an open question. The denomination of śāstra also applies to the Śivadharmaśāstra and the Viṣnudharmāḥ. (see Grünendahl, 1983: 66).
} 


\section{JOURNAL OF

In the course of preliminary research, my attention was drawn to a "historical" character named Dharmaśila appearing several times in lists of foreign physicians in the Tibetan tradition. ${ }^{15}$ A certain Darmaśila designated as a doctor and translator from Nepal (bal po) is mentioned in a passage devoted to "The Royal Dynastic Period" in the Bshad mdzod yid bzhin nor bu, a Tibetan compendium of knowledge by Don dam smra ba'i seng ge (late fifteenth century):

"[...] During the reign of Khri sde gtsug rtan aag-tsom, the two (physicians), the Nepalese physician Darmaśila and the Greek physician Rtsanpa the ho-shang, translated many medical treatises." 16

Based on the Old Tibetan Annals, king Khri lde srong btsan Mes ag tshoms (704-circa 754) would have reigned from the year $712 .{ }^{17}$

As pointed out by Frances Garrett (2007), the Tibetan physician Brang ti (fourteenth century) also mentions a list of nine foreign physicians who came to Tibet, but during the reign of the king Khri srong lde btsan (r. 756-97). Among the names included in this list is a certain "Dha la shi la," sometimes understood as "Dānaśila," physician and translator from Nepal. In the Zur mkhar blo gros rgyal po (16th c.), which contains the same list, the name is spelled slightly differently, as "Dharmā shi la." A list of names and regions identical to that of Brang ti is also found in Jaya Pandita's seventeenth-century Thob yig. 18

This information is of interest insofar as the Dharmaputrika was transmitted to us via a Nepalese manuscript tradition, contains technical terms which indicate a familiarity with Buddhism (see below), and its yoga teachings attest to a strong knowledge of classical medicine. If the hypothesis of a transmission of the Dharmaputrika by the son of a certain Dharmaśila who would have travelled to Tibet in the middle of the eighth

\footnotetext{
${ }^{15}$ My sincere thanks to Alexander Schiller, who guided me in Tibetan sources and verified the original text of the Bshad mdzod yid bzhin nor bu from the Delhi edition of 1969, and to Michael Torsten Wieser-Much, who brought the article by Christopher I. Beckwith (1979) to my attention.

${ }^{16}$ The Bshad mdzod yid bzhin nor bu is not translated. I quote here the translation of this passage by Christopher I. Beckwith (1979: 311, note 38).

17 Dotson, 2009: 143.

${ }_{18}$ This information is based on Garrett, 2007: 369-71 and note 5. On Blo gros rgyal po explaining that it was during the time of king Khri lde srong btsan (r.756-97) that "nine doctors arrived from India, Kashmir, China, Tazig, Drugu, Dolpo, and Nepal," see Garrett (2007: 374-77). On the difficult question of this list of foreign physicians in Tibet, see Dan Martin (2011: 133-135 and Appendix E). See also Dan Martin (2017), who gives information on the textual sources of this list, adding an old source: "An old medical history by a Zhijé school follower named Nyedowa, dating to somewhere around 1300." Retrieved from: https://tibeto-logic.blogspot.com/2017/. Accessed on: December 12, 2019.
} 


\section{JOURNAL OF

century were to be confirmed, this would constitute valuable information on the early history of the transmission of the Dharmaputrika and the formation of the Sivadharma corpus. However, in the current state of research, there is no fact to formally identify the compiler or author of the Dharmaputrika as being the son of a translator of medical texts in the reign of king Khri lde gtsug btsan Mes ag tshoms (712-circa 754) or king Khri srong lde btsan (756-97).

\section{The Dharmaputrikā and the Śivadharma corpus ${ }^{19}$}

Little is known about the dating and socio-religious milieu from which the texts pertaining to the Sivadharma corpus originate. Sanderson (2012) considers it to be an early body of Śaiva literature meant for the laity, in contrast to initiatory Śaivism. ${ }^{20}$ Discussions are currently in progress regarding the individual dating of the texts and the period of time over which the entire corpus developed. So far, the studies have focused on the first two texts, the Sivadharmaśāstra and Sivadharmottara, which are considered to be the earliest texts of the corpus.

The terminus ante quem for both the Sivadharmaśästra and the Sivadharmottara is the eighth century, a date established by Goodall (2011) on the basis of a paleographic evaluation of a fragmentary manuscript. ${ }^{21}$ Regarding the Śivadharmaśāstra, Hazra (1985) had proposed dating it between 200 and $500 \mathrm{CE} ; 22$ we now know that this text cannot be earlier than the fourth century based on iconographic arguments;23 Bisschop (2018) recently proposed an ante quem date of $630 \mathrm{CE}$, on the basis of a quotation in the Kārandavyūhasūtra. ${ }^{24}$ Regarding the Sivadharmottara, Hazra had estimated a date of composition between 700 and $800 \mathrm{CE} ; 25$ however, Goodall has suggested that the Sivadharmottara might be situated at least a century earlier. ${ }^{26}$ To briefly summarise, the

\footnotetext{
${ }^{19}$ In the present article, quotations from the Śivadharmaśāstra and Śivadharmottara are based on the apograph of the Wellcome Library.

20 Sanderson, 2012. (Handout 5, 22 February: 10-14.)

21 Goodall, 2011: 232, note 33.

${ }^{22}$ Hazra, 1985: 296.

23 See Sanderson, 2012 (Handout 5, 22 February: 12, note 19). Sanderson summarises the arguments on the terminus a quo of the Śivadharmaśāstra based on the fact that the cult and image of Vināyaka (mentioned in the Śivadharmaśāstra) are only attested from the fourth century CE. These arguments were developed by Törzsök (2004: 19) and taken up by Bisschop (2010: 244).

24 Bisschop, 2018: 14-15.

25 Hazra, 1983: 206.

26 Goodall, 2011: 232, note 33.
} 


\section{JOURNAL OF \\ YOGA STUDIES}

2020 - Volume 3

date of composition of the Sivadharmottara cannot be much later than that of Sivadharmaśāstra, and the two texts were probably composed over a fairly short period, around the beginning of the seventh century.

So far, there is a consensus among scholars on the formation of the corpus, which would be the result of a somehow linear production, from the two supposedly older texts, the Sivadharmaśästra and the Sivadharmottara, whose popularity would have instigated the writing of the others. ${ }^{27}$ This view logically led to considering the Dharmaputrikā, the last text of the corpus, as a "late Śaiva yoga text." 28 The problem is that all texts pertaining to the Śivadharma corpus certainly meet this linear conception of the formation of the corpus, except the Dharmaputrikā, which cannot be read as being elaborated from them. Therefore, the name "Dharmaputrikā" can refer neither to the Śivadharmaśāstra nor the Sivadharmottara as its source of derivation. ${ }^{29}$ Indeed, the differences between the Dharmaputrikā and these two texts are formally and substantively numerous. Here are some significant examples:

Both the Śivadharmaśāstra and the Śivadharmottara are in the form of a dialogue between sages, which itself relates to an original dialogue between Śiva and Pārvatī. This is the typical scheme of Purānic and Āgamic literature, the dialogical form legitimizing and elucidating the paramparā. In contrast, the Dharmaputrika $\bar{a}$ is not in the form of a dialogue but, as aforementioned, is simply introduced by a "human" author who assigns the original diffusion of the text to Sanaka.

\footnotetext{
27 "The Śivadharmaśāstra and the Śivadharmottara enjoyed great popularity in Nepal, where they kindled the growth of a whole collection of analogous Śaiva works, probably on account of the success enjoyed by Śaivism from the seventh century onward in this region. These works are transmitted together in a large number of multiple-text manuscripts, among which are some very early and well preserved specimens. This circumstance has induced scholars to speak of a 'Śivadharma corpus' [...]” (De Simini, 2016b: 63).

${ }^{28}$ See Kafle, 2015: 271. The New Catalogus Catalogorum (NCC) vol. IX (1977) also argued in favour of a late date: "Dharmaputrikā - On yoga in 16 chs. of philosophical and tāntric nature; prob. composed in 1069 A.D. in the reign of Śankara Deva. Nepal I. p. 92. pref. p. xlviii. Rep. Hpr.1895-1900, p. 6." It is the date of the copy of the manuscript (as for the Sanskrit text of the colophon which quotes Śankaradeva, see Petech, 1984: 46).

${ }^{29}$ The title "Dharmaputrikā" does not betray any Śaiva affiliation, in contrast to the titles of the other texts in the Śivadharma corpus. For now, there is no satisfactory explanation for "dharmaputrikā," which is the title attributed to this text so far. It echoes dharmaputra, "son of Dharma," the name by which king Yudhișthira is designated in the Mahäbhärata, the Vișnudharmāh, etc. But there is no reference to Yudhișthira in the text. Rather, I think we should consider "dharmaputrikā sam hitā" to be the complete title. Most probably it could refer to the author of the text, presenting himself as "the son of Dharmaśila," meaning "the saṃitā derived from, that is, composed by, the son of Dharma[śîla]." In this case, dharmaputrikā would be an adjective whose suffix -ika denotes belonging or derivation, without the expected initial vrddhi (-pautra / -pautrika). If we accept this hypothesis, "dharmaputrikā samhitā" would remarkably point to the human origin of the text.
} 


\section{JOURNAL OF \\ YOGA STUDIES}

2020 - Volume 3

Another difference is that the Sivadharmaśāstra and the Sivadharmottara teach a sivadharma in line with the social Brahmanical organization into four classes. In these texts, varna is used to designate the four classes. ${ }^{30}$ In contrast, the Dharmaputrika mentions neither the brähmanas nor the kșatriyas or the vaiśyas, and only once the śüdras (DhPS 16.12), and the term varna is never used to mean "class." Furthermore, the teachings of the Dharmaputrika are opened to a wide range of people, including women and foreigners (mleccha), and accessible to all castes and stages of life. This is explicitly stated in chapter Sixteen (see detailed summary).

The most striking distinctive feature of the Dharmaputrikā is that no external worship of any Brahmanical deity is mentioned, and, in particular, no mention of a cult of the Linga, while, as regards the Śivadharmaśāstra and Śivadharmottara, "the main pillar of this worldly religion is the worship of Siva in his aniconic representation of the Linga." 31 There is also no hint of any devotional expression towards Śiva or any other deity, or even to a master. In particular, the absence of a five- or six-syllable mantra (pañcākșara or șadakșara) should be noted. In fact, no sectarian emphasis can really be argued, which seems to indicate an absence of socio-religious tensions, in contrast to the Sivadharmaśāstra and the Sivadharmottara, which are replete with the name of Siva used as an iconic vehicle for spreading the Saiva religion. Singularly, and to say it another way, the Śaiva components in the Dharmaputrikā do not play any functional role in the accomplishment of yoga.

The fact that the Dharmaputrika is invariably the last text of the Śivadharma corpus and is replaced in one multiple-text manuscript dated from the eleventh century with the Lalitavistara raises the question of whether it belongs to the "Śivadharma corpus" proper. Rather, it seems that we are at the limit here of the heuristic value of the idea of a "Śivadharma corpus," since two parallels make it possible to connect the Dharmaputrikā with the Sivadharmottara and suggest with reasonable certainty that the Dharmaputrikā predates the Śivadharmottara and most probably the Śivadharmaśāstra.

\section{Śivadharmottara: A parallel to Dharmaputrikā 1.17-18}

In the "Section on instrumental principles" (sādhanaprakarana) of the Dharmaputrikā, in the subdivision dedicated to the six ancillaries (șadanga), dhyāna is defined as follows

\footnotetext{
30 See for example Śivadharmaśāstra 11.1-2 (W 52r): nandikeśvara uvāca | sarveșām eva varṇānāṃ śivāśramanișevi[n] $\bar{a} m$ | śivadharmah śivenokto dharmakāmārthamuktaye | brāhmaṇah kṣatriyo vaiśyah strī śūdro vā grhaśramī [Levi ms (33v) = śivāśramī] | vānaprastho gṛhastho vā ya[ś] cānyo vā grhāórramī|.

${ }^{31}$ De Simini, 2016b: 50.
} 


\section{JOURNAL OF \\ YOGA STUDIES}

$2020 \cdot$ Volume 3

(DhPS 1.17-18):

ko dhyeyah kas tv asau dhyātā kim dhyānaṃ kiṃ prayojanam |

catvāry etāni yo vetti sa yogi yogya ucyate |

dhyeyah śivo dhyātr mano dhyānam ekāgracittatā |

duḥkhahānir guṇaiśvaryaṃ svātantryạ̣ ca prayojanam |

What is the object of meditation? Who is the meditator? What is meditation? What is the purpose? Whoever knows these four [things] is called a yogin qualified for yoga. The object of meditation is Siva; the meditator is manas; meditation is the fact that the mind is [focused] on a single [object]; the purpose is the cessation of suffering, the mastery of qualities, and freedom.

These four components are also found in the Sivadharmottara 10, a chapter dedicated to yoga. Sivadharmottara 10 (W $\left.119^{\mathrm{r}}-119^{\mathrm{v}}\right)^{32}$ reads:

dhyātā dhyānam tathā dhyeyaṃ yac ca dhyānaprayojanam | etac catușțayam jñātvā yogaṃ yuñjita yogavit |

jñānavairāgyasampannaḥ śraddadhānaḥ kṣamānvitaḥ|

śivabhaktah sadotsāhī dhyātettham purușah smṛtaḥ|

dhyai cintāyāṃ smṛto dhātuḥ śivacintā muhur muhuḥ|

jñānena pariśuddhena jñānaṃ dhyānam atah param |

sakalah sa tu tattvajñah sarvajñah sarvadah prabhuḥ|

nānārūpavikalpena dhyeyaḥ siddhyartham iśvarah |

vimuktipratyayah pūrvam aiśvaryam cānimimādikam |

ity etad dvividhaṃ jñeyam śivadhyānaprayojanam |

The meditator, meditation, the object of meditation, and the purpose of meditation: having learnt these four [principles], the knower of yoga should practice yoga. A devotee of Śiva, ever persistent, endowed with knowledge and detachment, fervent and submissive: such a man (purusa) is termed meditator. The verbal root dhyai- refers to thought. The constant thought of Śiva [produces] knowledge, with perfectly pure

\footnotetext{
32 These verses of the Śivadharmottara were borrowed by the author of the Vāyaviyasamhitā and tailored to its teachings (see VāSa 2.29.164cd-169ab). Dated from the eleventh century at the latest, the Vāyavĩyasamhitā, which has been transmitted as a saṃhitā of the Sivapurāna, is the oldest and most systematic textual testimony of the reception of the Sivadharmaśāstra and Śivadharmottara in South India. In particular, its chapter Twenty-nine on yoga borrows many verses from chapter Ten of the Śivadharmottara. On the relationship of the Vāyaviyasaṃhitā with the Śivadharmaśāstra and Śivadharmottara, see Barois (PhD Thesis, 2012, vol. 1: 139-40).
} 


\section{JOURNAL OF \\ YOGA STUDIES}

$2020 \cdot$ Volume 3

knowledge then meditation [is produced]. To ensure success, the object to be meditated upon is Ísvara through different mental conceptions: having parts, knowing reality, omniscient, all-bestowing, and powerful. First, experience of liberation, [second] sovereignty [which consists of] atomicity, etc., these should be known as the twofold purpose of the meditation on Śiva.

The Dharmaputrikā explains dhyāna by brief but clear definitions of its four components, dhyātr, dhyāna, dhyeya, and prayojana, in the first subdivision of the first chapter, dedicated to the six ancillaries (șadanga) (see detailed summary $\S 1.1 .2$ ). This explanation of dhyāna takes place after the explanation of withdrawal (pratyāhāra) and before that of breath elongation (prānāyāma). In the Sivadharmottara, these same four components, dhyātr, dhyāna, dhyeya, and prayojana, are defined in a more expanded way, centred on injunctions relating to devotion to Śiva and elements of Śaiva theology. Unlike the Dharmaputrikā, the definitions of these four components are not included in a systematic teaching. Rather, they show a Śaiva phraseology characteristic of the Śivadharmottara (but also the Śivadharmaśāstra and the other texts of the corpus). In the Sivadharmottara, the meditator is the devotee of Śiva (śivabhakta). In the Dharmaputrikā, the meditator (dhyātr) is manas, which corresponds perfectly to its function throughout the yoga process expounded in the text. The conciseness of the definitions as well as the mention of manas as meditator are distinctive features indicative of the practicalities of teaching. This would argue in favour of the earliest attestation of these four components in the Dharmaputrikā. However, a similar definition of dhyāna as divided into components formed from the verbal root dhyai certainly was a widespread model at an early date, as different formulations on the same pattern are also found in the Viṣnudharmāḥ, the Sarvajñ̄annottaratantra (Yogapāda), and the Lingapurāṇa. ${ }^{33}$

\footnotetext{
33 Viṣnudharmāh 100.62ab: dhyeyaṃ brahma pumān dhyātā upāyo dhyānasaṃjñitaḥ| (Grünendahl 1989, Part 3: 140); Lingapurāṇa 1.28.5-6: pure śete puram deham tasmāt purușa ucyate | yājyam yajñena yajate yajamānas tu sa smṛtah | dhyeyo maheśvaro dhyānaṃ cintanaṃ nirvṛtih phalam | pradhānapurușeśānam yāthātathyaṃ prapadyate | (Shastri 1980: 28). Sarvajñānottaratantra (Yogapāda): yo dhyātā yac ca taddhyānam tad vai dhyānaprayojanam | sarvāny etāni yo vetti sa yogam yoktum arhati | àtmā dhyātā mano dhyānam dhyeyah sūkșmo maheśvarah | yat [param] paramaiśvaryam etad dhyānaprayojanam | (Vaidyanathan 1993, Part II: 3-4). The definition of the Sarvajñānottaratantra (Yogapāda) seems closer to that of the Dharmaputrikā than to that of the Śivadharmottara; however, the passage appears corrupt (for the first hemistich, Vasudeva [2004: 431, note 177] proposes the following conjecture, based on the commentary of Aghoraśiva: yo dhyātā yac ca taddhyānam taddhyeyạ̣ ca prayojanam |). Rather unusually the Śivadharmottara, which is not an erudite text, defines meditation as follows: dhyai cintāyām smrto dhātuh, dhyai cintāyām being the traditional gloss of the root dhyai in the Dhātupātha. The Śivadharmottara felt the need to add "dhātu." Perhaps it borrowed this part of the definition from Kauṇịnya ad Pāśupatasūtra 5.24: dhyai cintāyām | dhyānam cintanam ity arthah | uktaṃ hi| dhyai cintālakșaṇaṃ dhyānaṃ brahma cauṃkāralakșaṇam | dhīyate līyate vāpi tasmād dhyānam iti
} 
While it is also worth considering that the Sivadharmottara's quadripartite definition was borrowed from the Dharmaputrikā on the basis of another significant parallel with the Dharmaputrikā (see below), a third independent source cannot be excluded.

\section{Śivadharmottara: A parallel to Dharmaputrikā 1.37cd-38ab}

Verse 1.37cd-38ab of the Dharmaputrikā gives a list of six disciplines (sațāadhana):

utsāho niścayo dhairyam santoṣas tattvadarśanam |

kratūnām copasaṃhāraḥ șațsādhanam iti smṛtam |

Perseverance, resolution, constancy, satisfaction, perception of principles, and cessation of sacrificial rites, these are the six disciplines.

A variant of this verse is also found in Sivadharmottara 10 (W 122r):

utsāhān niścayād dhairyāt santoșāt tattvadarśanāt |

muner janapadatyāgād șaḍbhir yogaḥ prasiddhyati |

Yoga is accomplished by means of [these] six: through perseverance, resolution, constancy, satisfaction, perception of principles, and abandonment of inhabited places by the sage.

While in the Dharmaputrika the list of the six disciplines (DhPS 1.37cd-38ab) is followed by the precise explanation of each discipline separately (see detailed summary § 1.3) and the topic itself is announced as one of the eight subdivisions at the beginning of chapter One, the parallel verse in the Sivadharmottara lacks any contextual link. The rewriting of the second hemistiche is probable, replacing sațādhanam with șadbhir yogah, as the six disciplines are absent from the Sivadharmottara, and replacing kratūnām copasaṃhärah with janapadatyāgād, the "abandonment of inhabited places" referring here to the practice of perambulation, while in the Dharmaputrikā kratūnām copasamhärah means ceasing to perform the Vedic rites (see the detailed summary, $\S 1.3) .34$

Given the lack of context of the above parallel passages in the Sivadharmottara, I suggest that the Dharmaputrikā is the source, implying its terminus ad quem is the seventh

smrtam | muhūrtārdham muhūrtạ̣ vā prānāyāmāntare 'pi vā | dhyeyam cintayamānas tu pāpam kṣapayate narah | ìta ityājñāyām niyoge ca | oṃkāra eva dhyeyo nānya ity arthah | āha oṃkāro dhyeyah | (Shastri, 1940: 125). More probably this type of definition was simply scholarly knowledge popularized and adapted according to context.

${ }^{34}$ On this parallel, see also below "Reception of the Dharmaputrikā teaching in the Hathayoga tradition," p. 32. 


\section{JOURNAL OF \\ YOGA STUDIES}

2020 • Volume 3

century, which is the estimated date of composition of the Sivadharmottara. Since the Sivadharmaśāstra was supposedly composed shortly before the Sivadharmottara, it is very likely that the Dharmaputrikā precedes both the Śivadharmaśāstra and the Sivadharmottara. This would make the Dharmaputrikā the earliest surviving practical manual on yoga.

A two-stage elaboration of the Dharmaputrikā, as suggested by the introductory and concluding verses of the text, namely, an original treatise (śästra) disseminated by Sanaka, then a collection (samhitā) composed by the son of Dharmaśila, suggests the writing down of a teaching that had presumably been transmitted orally, the content of which is certainly old.

In the current state of research, it is not possible to know whether the Sivadharmottara borrows directly from the samhitā as it has been transmitted to us by the Nepalese manuscript tradition, or from an oral teaching of the yoga techniques as expounded in the Dharmaputrikā. Given the decontextualized nature of the parallels and, more generally, the low level of specialization of the yoga practices described in the Sivadharmottara, it is in any case evident that the author(s) of the Sivadharmaśästra and the Sivadharmottara were not engaged in the practice of yoga as expounded in the Dharmaputrikā. In the Sivadharmaśāstra, as in the sivadharmottara, sivayogins hold a central position, as mentioned by De Simini: “[...] the best human recipients are those who are identified with Siva and whose cult is thus equivalent to his own, that is the Śaiva yogins (śivayogin); this is noted several times in the Śivadharmaśāstra and becomes a central issue in the Sivadharmottara." 35 This is precisely the point: the specific use of the term śivayogin aims to convey an identification with Śiva. ${ }^{36}$ The discourse on yoga in the Śivadharmaśāstra and the Śivadharmottara is situated vis-à-vis yogic practices from an external perspective, essentially concerned with including yogins in the framework of Śaiva theology. In contrast, the Dharmaputrikā, a practical manual of yoga, never mentions śivayogins, but only yogins. The comparison between the Dharmaputrika and the other texts of the Sivadharma corpus, in particular the Sivadharmaśāstra and the Sivadharmottara, emphasises the discrepancy between, on the one hand, practical teachings and, on the other, an all-inclusive (but not universal) sectarian discourse correlated to kingship, using yoga practices as an instrument for Śaiva propaganda. Within a broader scope, it seems that in place of ancient yoga techniques that were difficult to implement and constraining, early sectarian movements proposed a more direct and easy method of yoga to achieve liberation through Śiva or Viṣnu. This turn is

35 De Simini, 2016b: 59.

36 The term śivayogin also occurs in the Skandapurāna, in the context of the pāśupatayoga exposition. 


\section{JOURNAL OF \\ YOGA STUDIES}

2020 - Volume 3

closely linked to the cult of images, which was Linga worship in the case of the Śivadharmaśāstra and Śivadharmottara. ${ }^{37}$

\section{Some preliminary remarks on other parallels to the Dharmaputrikā}

The textual parallels identified at this first stage of study and indicated in footnotes in the detailed summary (below) are from texts all of which predate the seventh century: the Mundaka Upanișad, the Bhagavadgitā, and probably the Maitrāyaniya Upanișad, as well as two early Purānas, that is, the Vāyupurāna and the Mārkandeyapurāna. In addition to these, sections on yoga in the Mahābhärata (in particular the Mokșadharmaparvan), the Niśvāsatattvasamhitā (in particular the Uttarasūtra and the Nayasūtra), and the Skandapurāna (in particular chapters One hundred and eighty-one and One hundred and eighty-two) present some shared terminology or commonalities relating to the yoga process, but with different wording and without ever presenting a level of technicality and consistency similar to the Dharmaputrikā. The precise relationships of these texts with the Dharmaputrika are difficult to disentangle, because the parallels do not exceed one or two verses and the texts concerned have multiple layers and intertextual links that have yet to be studied. For example, the parallel verses identified in chapter Ten of the Dharmaputrikā (see detailed summary, note 150) belong to a longer passage parallel to the Vāyupurāna, the Mārkandeyapurāna, and Sivadharmottara 10;38 the Maitrāyanīya Upanișad borrows from the Mundaka Upanișad, both texts containing an archery metaphor which is used in the Dharmaputrikā as a didactic tool to illustrate practice (see detail summary $\$ 4.3 .5$, note 131);39 furthermore, there might be indirect intertextual links between the Maitrāyanīya Upanișad and the Niśvāsatattvasaṃhitā, Nayasūtra, since

\footnotetext{
37 See, for example, chapter Ninety-nine of the Vișnudharmāh, which distinguishes between two kinds of yoga: "The para form is directed towards the highest brahman, named Vișnu. Due to the subtleness of brahman and to the fickleness of the mind, brahman can only be grasped after constant efforts through many existences. The enormous difficulties of this form of yoga can be avoided by choosing the apara form, which is directed towards a visual image of Viṣnu" (Grünendahl, 1989: 24-5).

${ }^{38}$ These three passages demonstrate a close relationship between yoga and medicine at an early date.

39 Another significant example is that Maitrāyaniya Upanișad 6.18 borrows from Muṇdaka Upanisad 3.3. Muṇ̃aka Upanișad 3.3: yadā paśyah paśyate rukmavarnam kartāram iśam purușaṃ brahmayonim | tadā vidvān punyapāpe vidhūya nirañjanaḥ paramaṃ sāmyam upaiti | 3 |

Maitrāyanīya Upanișad 6.18: tathā tatprayogakalpah - prāṇāyāmah pratyāhāro dhyānam dhāraṇā tarkah samādhị șaḍangā ity ucyate yogạ̣ | anena yadā paśyan paśyati rukmavarṇạ̣ kartāram iśam purușạ̣ brahmayoniṃ tadā vidvān punyapāpe vihāya pare'vyaye sarvam ekikaroti |, "The technique is the six-membered yoga, viz. breath control, withdrawal of the senses, concentration, retention, consideration, complete fastening. When, seeing through yoga one sees the golden-colored doer, the sovereign purușa who springs from Brahman, then, being enlightened, relinquishing good and evil acts, one unifies everything in the supreme and imperishable" (text and translation by van Buitenen, 1962: 111-12 and 142).
} 


\section{JOURNAL OF \\ YOGA STUDIES}

2020 - Volume 3

the four metaphors that open chapter One of the Nayasūtra share some similarities with metaphors in the Maitrāyaniyya Upanișad. 40

On first examination, it seems unlikely that the Vāyupurāna and the Mārkandeyapurāna are direct sources from which the Dharmaputrikā would have drawn. Rather, these close parallels may attest to the existence of a diffused practice of yoga as a shared knowledge on soteriological bodily techniques around the fifth-sixth centuries.

Among the textual divisions of the Niśvāsatattvasaṃitā, the Uttarasūtra (seventh century) and the Nayasūtra (seventh century) deal in part with yoga. A preliminary observation shows some similarities between the yoga expounded in these texts and the Dharmaputrikā. As in the Niśvāsatattvasamhitā, Uttarasūtra 5.37, the Dharmaputrikā mentions only two channels (sușumnā and $i d \bar{a}$ ), and there is no mention of a central channel. ${ }^{41}$ As is the case in the Niśvāsastattvasamhitā, there is no occurrence of the term dvādaśānta in the Dharmaputrikā. ${ }^{42}$ Furthermore, the Niśvāsatattvasaṃhitā, Nayasūtra 4.128-129 mentions the names of three subsidiary bodily winds, nāga, dhanañjaya, and kürma, in a passage on the breaths which seems to relate to the same context of practice as in the Dharmaputrika, the passage mentioning the five subsidiary bodily winds in action during the process of dying (see detailed summary, § 4.3.5). These similarities with the Niśvāsatattvasaṃhitā pertain exclusively to yoga techniques (in particular, the conquest of the bodily winds), and not to specific Śaiva categories. Based on the publication of the Niśvāsatattvasaṃitā, the "earliest surviving Śaiva tantra," the idea has been proposed that the standardization of technical terminology, such as the three phases of prāṇāyāma, recaka, pūraka, and kumbhaka (absent from the Pātañjalayogaśāstra), should be credited to the early Tantric texts. ${ }^{43}$ Rather, technical terms like recaka, püraka, etc. relating to physiological functions may connote a specialized language issuing from ascetic or medical circles. The language of classical medicine is based on such a terminology derived from action verbs designating bodily actions or processes

40 As example, Niśvāsatattvasaṃhitā, Nayasūtra 1.9 (ayaspinḍdo yathā dhmātaśchidyamānastu khandaśăh | na ca chinattyasau vahnis tadvajijivo na cchidyate |) is close to Maitrāyañiya Upanișad 3.3 (atha yathāgnināyahpiṇ̣̂o vābhibhūtah kartṛbhir hanyamāno nānātvam upaity evam vāva khalv asau bhūtātmāntah puruṣenāahibhūto gunair hanyamāno nānātvam upaiti |), where the parallel use of the rare compound ayahpinda is to be noted. In the Nayasūtra the compared is jīva, in the Maitrāyaniyya Upanișad the compared is bhütātman. This would mark indirect textual links only, since Maitrāyañiya Upanișad 3.3 is a late passage introduced by the mention: athānyatrāpy uktam |

${ }^{41}$ In the Niśvāsatattvasaṃhitā, Uttarasūtra 5.37, the mention of suṣumnā and iḍ̄a is in the context of the homologisation of breathing movements with planetary movements. See Goodall, 2015: 33-34 and 397.

42 See Goodall, 2015: 34.

${ }^{43}$ According to Goodall (2015: 490), the Niśvāsatattvasaṃhitā, Nayasūtra 4.111 would be among the earliest attestations of recaka, pūraka, and kumbhaka used to describe the prānāyāma. 


\section{JOURNAL OF \\ YOGA STUDIES}

$2020 \cdot$ Volume 3

(for example recana), while Tantric texts, characterized by their invention of hierarchical ontologies, are not particularly acquainted with this lexical field. If we compare the technical (non-theistic) yoga elements of the Dharmaputrika with the expositions on yoga transmitted by the Tantric tradition, Saiva in particular, it should be noted that the latter show a remarkable lack of interest in the knowledge and techniques of the body, from either a functional, therapeutic, or prophylactic point of view. It is as if the Tantric textual traditions had retained only the basic structure of a yoga practice, leaving aside knowledge on the internal process not immediately serving their purpose, which would also explain the unsatisfactory and fragmented nature of Tantric yoga in general.

The Skandapurāna also contains chapters expounding an ancient śaivayoga called pāsupatayoga (chapters One hundred and seventy-four to One hundred and eighty-two, not critically edited to date), which would be worth examining in comparison with the

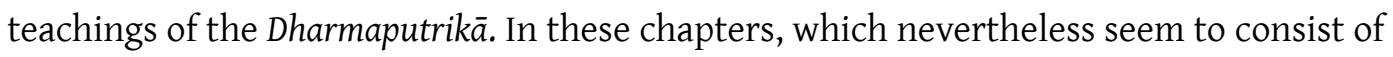
composite material, Brahman is mentioned several times, the role of manas is prominent, as well as the practice of OM. In particular, chapter One hundred and eighty-one describes an ascent which involves the five subsidiary bodily winds (each cited by name), and may constitute an ancient testimony of a technique similar to that described in the Dharmaputrika under the name "ascent up to dissolution" (pralayotkrānti) (see detailed summary, § 4.3.5).

The teachings on yoga in Maitrāyaniya Upanișad 6.18-31 notably echo those of the Dharmaputrikā. Besides particular shared features such as the archery metaphor (Maitrāyaniya Upanișad 6.24) or the mention of a "fourth" ultimate place or channel (Maitrāyañiya Upanișad 6.19), the general definition of yoga in the Maitrāyañiya Upanișad agrees very closely with the yoga practice described in the Dharmaputrikā: the exclusive use of OM in the course of practice, the combined functioning of the bodily winds and manas, the withdrawal of the senses, which is its ultimate phase. ${ }^{44}$ This section of the Maitrāyaniya Upanișad also specifies the ancillaries of a șadangayoga (Maitrāyaniya Upanisad 6.18) which correspond, in a different order, to those of the Dharmaputrikā as well as the technical name sușumnā (Maitrāyaniya Upanișad 6.21). As stated by van Buitenen (1962: 13), the sixth and seventh prapațhaka of the Maitrāyaniyya Upanișad "appear to be full of inconsistencies and desultory portions, which have been described

${ }^{44}$ Maitrāyañīya Upaniṣad 6.25:

evaṃ prānam athoṃkāraṃ yasmāt sarvam anekadhā|

yunakti yuñjate vāpi tasmād yoga iti smrtah |

ekatvam prānamanasor indriyānām tathaiva ca|

sarvabhāvaparityāgo yoga ity abhidhīyate| 


\section{JOURNAL OF

as appendices, accretions, and, in part at least, interpolations." Although it has not yet been definitely proven, it is not unlikely that the Dharmaputrika $\bar{a}$, or a teaching representative of its yoga, is a source of the sixth prapațhaka of the Maitrāyaniya Upanișad.

A coherent practical text such as the Dharmaputrika, which testifies to the antiquity of respiratory techniques, is likely to open new perspectives with regard to the early history of yoga. The most recent discussions on the date of the Maitrāyaniya Upanișad consider that the late passages are of Tantric origin. This was asserted by Somadeva Vasudeva (2004) and restated by James Mallinson (2014).45 But it is not patently apparent that the sixth prapāțhaka of the Maitrāyaniya Upanișad is a Tantric text. Even if sadangayoga is mentioned at an early date almost exclusively in Tantric texts, I would be cautious about systematically linking it to Tantric contexts, and thereby concluding that the mention of a sadangayoga in the Maitrāyaniya Upanișad proves its debt to Tantricism. Indeed, the Dharmaputrikā does not characterize its yoga as a șadangayoga: rather, the six ancillaries are simply and solely presented as the first of the eight groups of instrumental principles described in chapter One (an important detail concerning their function during the yogic process is also given in chapter Thirteen). Similarly, the Vivaraña ad Pātañjalayogaśāstra 2.29 relativises the classification into eight or six ancillaries (on the links between the Dharmaputrikā and the Pātañjalayogaśāstravivaraṇa, see below p. 27). In contrast, the Śivadharmaśāstra explicitly mentions a "șadangayoga" 46 and the Nayasūtra is "aware of an existing șadangayoga," 47 both mentions referring to a yoga system external to the main subject and the purposive discourse of these texts. So, rather than attributing the source of the sadangayoga directly to the Tantric tradition, I would rather suggest that it was the Tantric tradition that systematized the mention of sadangayoga as a typology of yoga.

"Since the yogin fastens the prāna and OM and all in many different ways, therefore this technique is called 'Fastening.' The union of prāna, manas and senses, and the relinquishment of all objects is called yoga." (Sanskrit text and translation: van Buitenen, 1962: 113 and 144).

I propose this provisional translation of Maitrāyaniyya Upanișad 6.25:

"Since [manas] joins with prāna and OM in this way, or even [the senses] join with the diversity of the phenomenal world, it is called 'conjunction.' The union of manas and prāna, as well as the renouncing of all objects of the senses, this is called 'conjunction."

45 Vasudeva (2004: 376, note 18): "The Maitrāyaniyopanișad is often referred to as the most ancient witness to the existence of Șadangayoga. There is however no compelling reason to believe that this section of the text predates either the Jayākhyasaṃhitā or the earliest Śaiva sources consulted." Mallinson considers Maitrāyaṇiya Upanișad 6.18-31 "to be late 'Tantric' additions" (see Mallinson, 2014: 170).

${ }^{46}$ De Simini, 2016b: 51.

47 Goodall, 2015: 74. 


\section{JOURNAL OF \\ YOGA STUDIES}

$2020 \cdot$ Volume 3

In the Mahābhärata, besides some parallels of minor importance, ${ }^{48}$ some teachings in the Mokșadharmaparvan seem close to those expounded in the Dharmaputrikā, but without strict textual parallels. It is as if the teachings described in the Dharmaputrika were a later systematic formulation of yoga practices disseminated orally in various circles and present in a diffuse way in the Mahābhärata. Similarities may also be found in other sections of the Mahäbhärata in the context of the narrative of the death of the yogin, which would pave the way to evaluating the presence of technical teachings of yoga in narratives. ${ }^{49}$

The important issue of the influence of Buddhism goes far beyond the scope of this essay. The point should, however, be made that there is no strictly Buddhist philosophical or theological elaboration in the Dharmaputrika, but only the presence of a limited Buddhist terminology adapted to the yoga context, the most significant example being the use of "resolution" (cittotpāda) (see detailed summary 1.3), suggesting a proximity to the Mahāyāna Buddhism milieu. Also notable is the absence of social criteria for access to the yoga practice and its results (see chapter Sixteen). ${ }^{50}$ Pending further research, it should also be considered that chapter Four, dhyānamārgaprakaranam, shows similarities in terms of practice with the teachings of the Guhyasamajjottaratantra 143-154, as well as with the commentaries to these verses in the Kālacakra tradition. ${ }^{51}$

\footnotetext{
${ }^{48}$ For example, Dharmaputrikā 5.3cd: rșayah pitaro devā muhyante 'tra sukhepsavah | $\mid$ Mahābhārata 14.36.32cd: rșayo munayo devā muhyanty atra sukhepsavah $\mid$.

${ }_{49}$ This seminal question was raised by Peter Schreiner (1988: 14-15): "Entscheidend für die Beurteilung der episodischen Ausgestaltungen des Motivs vom 'Tod des Yogin' ist, ob die Verbindung von Yoga und Tod nur als erzählerisches Klischee einzustufen ist, oder ob ein systematischer, theoretischer Zusammenhang belegt werden kann und ob die religionsgeschichtliche Einordnung plausibel gemacht werden kann. Mit anderen Worten: Läßt sich das Motiv auch in anderen, z.B. lehrhaften Kontexten nachweisen und läßt es sich in Beziehung setzen zu einer denkbaren Abfolge von Vorstellungen und Lehren, die man aus anderen Texten und Perioden kennt? Auf zwei Aspekte wäre demnach zu achten, auf die ausdrückliche Erwähnung des Todes des Yogin, und auf terminologische Zusammenhänge mit Beschreibungen eines als Yoga bezeichneten oder zu Yoga führenden Weges."

${ }^{50}$ The class criterion was absent in certain branches of the pre-Śankarian Vedānta, as shown in the section on the Vedānta in the Madhyamakahrdaya of Bhavya (6th c.) and his autocommentary, Tarkajvālā. This was pointed out by Hajime Nakamura (1983: 214-15): “[...] on the question of practice, the Vedānta school which Bhavya reports had endeavoured to destroy the concept of class distinctions firmly maintained by the orthodox Brahmins. It was held that if one were to know the ātman, no matter who he might be, he could obtain the state of liberation."
}

${ }^{51}$ See Sferra, 2000: 130-36. 


\section{JOURNAL OF \\ YOGA STUDIES}

$2020 \cdot$ Volume 3

\section{The Dharmaputrikā and the Pātañjalayogaśāstravivaraṇa}

The Pātañjalayogaśāstravivaraña is a commentary of primary importance for the interpretation of the Pātañjalayogaśāstra. ${ }^{22}$ It is therefore an important discovery that verses of the Dharmaputrikā are cited in the Pātañjalayogaśāstravivarana. In the detailed summary (below), I indicate two significant parallels:

Firstly, the three methods of yoga (trividho yogah) discussed in the Dharmaputrika are also mentioned in the Vivaraṇa ad Pātañjalayogaśāstra 1.40 (see detailed summary, § 1.6 and note 98). This is all the more remarkable since, to my knowledge, such a description of this procedure is not found in any other yoga text.

Secondly, a quotation in the Vivaraña ad Pātañjalayogaśāstra 2.29, which has not so far been identified, can undoubtedly be attributed to the Dharmaputrika (DhPS 16.2-3, see detailed summary, chapter Sixteen, note 161).

An exhaustive presentation of the links between the Dharmaputrika and the Vivarana largely exceeds the scope of this essay. 53 As a very first step, the preliminary elements presented here demonstrate that the author of the Vivarana knew a yoga system similar to that expounded in the Dharmaputrikā.

How is the Dharmaputrikā referred to in the Pātañjalayogaśāstravivarana? The name "Dharmaputrikā" is not mentioned, and the quotation in the Vivarana ad Pātañjalayogaśāstra 2.29 is introduced by the general phrase: "Therefore it is said elsewhere" (yad anyatrocyate). However, a passage in the Vivaraña ad Pātañjalayogaśāstra 3.39 is very close to Dharmaputrikā $4.36-37$ and could possibly give an indication as to how the yoga system of the Dharmaputrikā was referred to. Pātañjalayogaśāstra 3.39 explains the physiological functions of the five breaths and defines prāna as the main breath (eșām pradhānah prāṇaḥ). In its gloss, the Vivaraṇa ad Pātañjalayogaśāstra 3.39 (Śāstrī and Śāstrī, 1952: 294) reads:

\footnotetext{
52 As noted by Philipp A. Maas (2013: 75): “[...] the Vivarana is an important source of knowledge for Yoga philosophy. [...] It explains difficult passages of the PYŚ on which Vācaspati's Tattvavaiśāradī remains silent and reflects important philosophical debates between Sānkhya-Yoga on the one hand, and Buddhist and orthodox Hindu schools of thought on the other. The role of the Vivarana for the interpretation of the PYŚ may be compared to that of the Yuktidipikā (Wezler - Motegi 1998) for understanding the philosophy of the Sānkhya Kārikās."

${ }^{53}$ A study would not consist solely in identifying parallels, but also in examining the structure of the practical teachings of the Dharmaputrika as compared to the textual organization of this commentary to the Pātañjalayogaśāstra.
} 


\section{JOURNAL OF

eteșām pradhānaḥ prāṇah | tajjayāc ca sarveșām apānādīnām tu jayo bhavati | teșām tu jayopāyo vistareṇa hairaṇyagarbhe vyākhyātah | iha tu manojayānujitatvāt teșāṃ jayopāyo na prrthag abhihitạ̣|

Prāna is the principal of these [bodily winds]. From the conquest of [prāna] follows the conquest of all the other [winds] beginning with apāna. The means of conquering these [bodily winds] was explained in detail in [the treatise] of Hiranyagarbha. But here, since [prānna] is conquered as a result of conquering the mind, the means of conquering [each bodily wind] separately is not mentioned.

Here, the author of the Vivarana clarifies that prāna is the principal bodily wind, and that victory over that wind induces victory over all the other winds, apanna, etc., which is exactly consistent with Dharmaputrika $4.36-37$. In the concluding verses of the passage on the conquest of the five bodily winds (pañcajaya) (see detailed summary, $\S 4.2)$, Dharmaputrikā 4.36-37 reads:

teșām madhye pradhānasya nirdoșasya viśeșatah | prānasyaiva jayābhyāsaṃ praśaṃsanti manīsininah | yadà tu prāṇam evaikaṃ yogì samyag vijeșyati | tadā sarve jitā eva bhavanty ete 'pi vāyavaḥ|

The sages praise the practice of the conquest of the mere prāna, the principal and particularly defectless amongst these [bodily winds]. When the yogin has conquered even only prana thoroughly, all the bodily winds are conquered.

Further, the Vivaraṇa ad Pātañjalayogaśāstra 3.39 indicates that the means of conquering (jayopayya) the bodily winds were explained in detail in a supposed treatise coming from Hiranyagarbha. This raises the question of whether this designation refers to the teachings of the Dharmaputrika, as there is no other surviving yoga text expounding such an elaborate description of the conquest of the five bodily winds..$^{54}$ The indication in the Vivarana that the means of conquering each bodily wind separately is not mentioned, since prāna is conquered as a result of conquering the mind, coincides intimately with the concluding verse on the five conquests in the Dharmaputrika, which states that the method of separately conquering the bodily winds applies in the context

\footnotetext{
${ }^{54}$ The Nayasuttra contains a few verses that deal with the conquest of the bodily winds in the exclusive context of exiting from the body (Niśvāsatattvasaṃhitā, Nayasūtra 4.131-136), which are far from reaching the level of detail given in the Dharmaputrikā.
} 


\section{JOURNAL OF \\ YOGA STUDIES}

2020 - Volume 3

of the five actions (pañcakarman) (see detailed summary, § 4.2), in contrast to the conjunction related solely to mind described in chapter Sixteen, which corresponds to what is called "manojaya" in the Vivarana. The fact that the original diffusion of the Dharmaputrika is assigned to Sanaka is also in favour of this hypothesis, as Hiranyagarbha is another name for Brahmā, and Sanaka is one of his mind-born sons. ${ }^{55}$

Another important point arising from the fact that the Dharmaputrika is cited by the Vivarana is that it is likely to contribute to the discussion on the authorship of the Pātañjalayogaśāstravivaraña. The latter is attributed to Śankara, but there are still ongoing debates to determine whether he is the celebrated eighth-century philosopher, author of the Brahmasūtrabhāșya, or a later author. An article in preparation explores the thesis that Śankara, the author of the Vivarana, is the same as the one who composed the Brahmasūtrabhāssya and the commentary on the Bhagavadgitāa, based on the textual parallels with the Dharmaputrikā in all three of these commentaries. ${ }^{56}$

Finally, the very presence of teachings of the Dharmaputrikā in the Pātañjalayogaśāstravivarana, while still to be fully evaluated, also raises the question of the nature of the link between the Dharmaputrikā and the Pātañjalayogaśāstra itself. While the Dharmaputrikā teaches how to practice, and its economy is typical of a practical manual, the Pātañjalayogaśāstra is considered to be "the foundational work of Yoga philosophy." 57 However, both are organic texts presenting a comprehensive yoga system and are in agreement as regards the structural aspects of the practice, such as the repetition of the syllable OM or the dissociation between repeated practice (abhyāsa) and detachment (vairāgya), which correspond to two phases of the yoga method in the Dharmaputrikā.58

An important contribution of the Dharmaputrika to the knowledge of ancient yoga practice is the insight it provides into the temporal phases and places of internal processes in the body, formulated in a more obscure and laconic way in other texts, and in particular the detailed explanation of a system of respiratory practices for soteriological purposes, of which we have otherwise only incomplete accounts. If links between the practical teachings of the Dharmaputrika and the philosophical Yoga

\footnotetext{
55 In this hypothesis, hairanyagarbha should be interpreted as "son of Hiranyagarbha" and would refer directly to Sanaka. An article in progress explores this hypothesis. It re-examines the references, in different sources, to hiranyagarbha and hairanyagarbha in relation to a particular yoga school, as compared to the yoga of the Dharmaputrikā Saṃhitā. Some of these sources are mentioned by Kane (1930-72, vol. 2: 1390-91).

${ }^{56}$ See Barois (forthcoming): “Śankara the Yogin and the Dharmaputrikā Sạ̣hitā.”

${ }^{57}$ Maas, 2013: 57.

58 Maas (2014: 69, note 13): “Laut Pātañjala-Yogaśāstra 1.12,2 sind die beiden Mittel zum Erreichen des Heilsziels des Yoga die Begierdelosigkeit (vairāgya) und Übung (abhyāsa).”
} 


\section{JOURNAL OF \\ YOGA STUDIES}

$2020 \cdot$ Volume 3

according to Patañjali were to be confirmed, this would make the teachings of the Dharmaputrikā a fulcrum for the understanding of the philosophical exposition of the Pātañjalayogaśāstra. So far, relevant publications dealing with the reconstruction of the yoga practice according to the Pātañjalaśāstra (that is, examination of the Pātañjalayogaśāstra in terms of temporality, order, and hierarchy of practice, by relying on internal references, that goes beyond the textual organization into four books), are very few; of these Strukturen yogischer Meditation by Oberhammer (1977) and Der Yogi und sein Heilsweg im Yoga des Patanjali by Maas (2014) are well worth consulting.

To summarize, the Dharmaputrikā is a practical yoga teaching addressed to yogins in a language that is clear, concise, and concrete. It has a different purpose than the other texts of the Śivadharma corpus, which are oriented towards the wide dissemination of the "religion of Siva" in line with the social conceptions of Brahmanism. My hypothesis is that the Dharmaputrika bears the testimony of an ancient yoga as a psychophysiological method freed from doctrinal backgrounds, whether Śaiva or Vaișnava. Combining breathing techniques and disciplines of renouncing desires within a Sāmkhya metaphysical framework as can be found in the Mahäbhārata, this method of great difficulty is necessarily the result of practices perfected by generations of yogins over a long period of time. This teaching would have been systematised and then transmitted by "the son of Dharmaśila," probably to a community of yogins close to the Śaiva milieu which produced the Sivadharmaśāstra and Śivadharmottara. It is not unlikely that the sivayogins held in so high esteem in these two texts were precisely practising yoga as taught in the Dharmaputrikā. This yoga teaching was also known to the author of the Pātañjalayogaśāstravivarana. It may be particularly fruitful to further investigate the possibility that this yoga is a testimony of the so-called Hairanyagarbhayoga.

\section{Reception of the Dharmaputrikā in the Hațhayoga tradition}

The Dharmaputrikā precedes by some time the flourishing of Hațhayoga literature, and a reuse of its teachings in the numerous Hathayoga texts which are characterized by intense intertextuality might have been expected. But this is not the case. Just as the Dharmaputrikā does not seem to have been taken into account or even known as a text by later Śaiva schools, the Hathayoga literature of the first part of the second millennium seems unaware of its existence.

According to the current state of knowledge, the Dharmaputrikā was not mentioned by name before the beginning of the sixteenth century. The earliest citation occurs in a text named the Yogacintāmaṇi, which was composed by a certain Godāvaramiśra, royal 


\section{JOURNAL OF \\ YOGA STUDIES}

2020 • Volume 3

preceptor (rājaguru) to Pratāparudradeva (1497-1539).59 In his Yogacintāmaṇi, Godāvaramiśra quotes verses from chapter Three of the Dharmaputrikā, which is devoted to postures, and he clearly attributes these verses to the Dharmaputrikā. He cites the description of the postures named mrgasvastika, 60 ardhacandra, añjalika, danda, and pițha. These same verses, in the same order, are also quoted in the Yogacintämani of Śivānandasarasvatī, a text that can be dated between the early sixteenth century to early seventeenth century and is modelled on the work of Godāvaramiśra. Śivānandasarasvatī also attributes this passage to the Dharmaputrikā (viśeșalakșanam tu dharmaputrikāyām). ${ }^{61}$ In the Yogacintāmaṇi of Śivānandasarasvatī, verses quoted from the Dharmaputrikā are grouped together, which is not the case in the Yogacintāmani of Godāvaramiśra. Neither Godāvaramiśra nor Śivānandasarasvatī quote the verses according to the order given in chapter Three of the Dharmaputrikā. They both chose specific postures (viśeșa), omitting the padma, sthala, and sarvatobhadra postures. Finally, this same list of postures is also cited in another text dated to the seventeenth century, the Yogasiddhāntacandrikā of Nārāyanatīrtha. ${ }^{62}$ Again, the verses cited do not follow the order given in chapter Three of the Dharmaputrikā. Nārāyaṇatīrtha cites the postures danda, mrgasvastika, ardhacandra, añjalika, and pițha. In the Yogasiddhāntacandrikā, the presentation of the postures borrowed from the Dharmaputrikā seems less systematic than in the Yogacintāmani of Śivānandasarasvatī. The descriptions of the postures are not grouped, as the posture called danda is separated from the others, and Nārāyanatīrtha does not mention the source of these postures, which seems to argue in favour of a borrowing by the Yogasiddhāntacandrikā from one of the two existing Yogacintāmani, rather than directly from the Dharmaputrikā.

\footnotetext{
59 It is thanks to Jason Birch (personal communication) that I became aware of the mention of the Dharmaputrika in the Yogacintāmaṇi of Godāvaramiśva and of the close links of this text with the Yogacintāmaṇi of Śivānandasarasvatī. For more information on the textual history and the dating of these two texts, see Birch and Singleton: The Wish-Fulfilling Gem of Yoga. The Āsana of the Yogacintāmani. (Forthcoming 2021). The date of Pratāparudradeva is according to Gode (1953: 475).

${ }^{60}$ This posture is simply called svastika in the Dharmaputrikā. In the Yogacintāmani of Godāvaramiśra, the Yogacintāmaṇi of Śivānandasarasvatī (1927: 153), and the Yogasiddhāntacandrikā of Nārāyaṇatīrtha (2000: 111), this posture is called mrgasvastika, the hands being in the mrgasírșa position, to differentiate it from the posture simply named svastika described in other texts. This differentiation does not exist in the Dharmaputrikā.

61 See Yogacintāmani (1927: 153). According to the Descriptive Catalogue of Sanskrta and Prakrta Manuscripts in the Library of the Bombay Branch of the Royal Asiatic Society (1928: 1081-83), Śivānandasarasvatī is a pupil of Rāmacandra Sadānandasarasvatī who lived in the early seventeenth century. For a presentation of the Yogacintāmani and its author, see Birch, 2013: 403 and 421, note 7, as well as Birch, 2018: $110 \mathrm{ff}$.

${ }^{62}$ See Yogasiddhāntacandrikā (2000: 109-11). I warmly thank Jason Birch for pointing out to me this list of postures in the Yogasiddhāntacandrikā. On these two texts, the Yogacintāmani and the Yogasiddhāntacandrikā, and on the proliferation of assanas in the second part of the second millennium, see Birch, 2018. On the author of the Yogasiddhāntacandrikā in particular, see Ko Endo, 1993.
} 


\section{JOURNAL OF \\ YOGA STUDIES}

2020 - Volume 3

The most striking encounter of the Dharmaputrika with the history of the Hathayoga literature is that its chapter Ten, "Medical treatment" (cikitsā), was added to the four regular lessons (upadeśa) of the Hathapradipikā in some late manuscripts of this text. This fifth chapter named ausadhakathanam or ausadhaprayogah according to the colophons was adopted in the edition of Swami Digambaraji and Raghunathashastri Kokaje $(1970,1998)$ on the basis of two manuscripts, one of which is dated 1706.63 It appears that the adjunction of a fifth lesson to the Hathayogapradipika coincides with a resurgence of manuscripts of the Dharmaputrikà alone, independent of the Sivadharma corpus. ${ }^{64}$ Among these manuscripts, those whose date is given (after the Nepalese German Manuscript Cataloging Project) postdate the estimated date of the Yogacintāmaṇi by Godāvaramiśra. Pending further research, it may be assumed that the rediscovery of the Dharmaputrikā by Godāvaramiśra in the early sixteenth century and the late addition to the Hathapradipikā of an entire chapter of the Dharmaputrika are closely linked to this resurgence of manuscripts. This false and late attribution to the Hathapradipikā, probably a direct consequence of the rediscovery of the Dharmaputrika in the sixteenth century, will need to be further examined in the framework of the critical edition of the Hathapradipika and the history of its reception.

Another fact that may contribute to the history of Hathapradipika is the presence of a verse parallel to the Dharmaputrika and the Sivadharmottara in the first lesson of the Hațhapradīpikā. Hațhapradīpikā 1.16 reads:

$$
\begin{aligned}
& \text { utsāhāt sāhasād dhairyāt tattvajñānāc ca niścayāt | } \\
& \text { janasangaparityāgāt șaḍbhir yogaḥ prasidhyati | }
\end{aligned}
$$

As mentioned above, Dharmaputrikā 1.37cd-38ab gives a list of six disciplines (utsāho niścayo dhairyam santoṣas tattvadarśanam | kratūnām copasaṃhāraḥ șațāāhanam iti smrtam |), which are then defined one by one, that is to say, this verse is contextualized, which is not the case for the parallel verse of Sivadharmottara 10 (W 122r) (utsāhān

\footnotetext{
${ }^{63}$ Hathapradipikā, Digambaraji and Kokaje edition (1998: xxiv). The two manuscripts in question are: No. 2402 of the Pune University Library (undated) and a manuscript preserved in the Sārvajanik Vācanālaya, Nāsik (dated śaka 1628).

${ }^{64}$ Manuscripts of the Dharmaputrikā dated from the seventeenth and eighteenth centuries: Kathmandu, National Archives, MS 65922 (NAK access number 9/537; NGMPP C107/7) dated to NS 803 (circa 1683 CE); Kathmandu, National Archives, MS 19068 (NGMPP E622/3) dated to NS 807 (circa 1687 CE); Kathmandu, National Archives, MS 19069 (NGMPP E723/17) dated to NS 815 (circa 1695 CE); Kathmandu, National Archives, MS 19074 (NAK access number 5/5364; NGMPP A299/9) dated to NS 845 (circa 1725 CE); Kathmandu, National Archives, MS 93317 (NGMPP E2069/2) dated to NS 863 (circa 1743 CE). These are the manuscripts dated after the Nepalese German Manuscript Cataloguing Project, but several other manuscripts of the Kathmandu, National Archives, undated so far, were probably also copied in about the same period.
} 


\section{JOURNAL OF \\ YOGA STUDIES}

2020 - Volume 3

niścayād dhairyāt santoṣāt tattvadarśanāt | muner janapadatyāgād șaḍhir yogaḥ prasiddhyati |). Hațhapradīikikā 1.16 being very similar to Śivadharmottara 10 (W 122r), it is almost certain that it borrows directly or indirectly from the Sivadharmottara, widely disseminated in South India, rather than from the Dharmaputrika, these elements standing as hypotheses given that the history of the diffusion of the Sivadharmottara in South India is complicated. Hațhapradipika 1.16 appears to be more contextualized, as it follows on from a list of six negative behaviours (atyāhārah prayāsaś ca prajalpo niyamāgrahah | janasangaś ca laulyam ca șadbhir yogo vinaśyati |). In the absence of a critical edition, it is difficult to say more about this particular verse, except that it opens the way to further research on the links between the Hathapradipika and the Śivadharma corpus.

\section{Detailed Summary of the Dharmaputrikā}

The detailed summary presented here is the result of research preliminary to the ongoing critical edition, and the textual parallels indicated do not claim to be exhaustive.

\section{Chapter One: "Section on the instrumental principles," sādhanaprakaranam (74 ślokas)}

Following two propitiatory stanzas, 65 chapter One introduces the Dharmaputrika by stating that the success (siddhi) of the conjunction (yoga) depends on the understanding of sixteen means of accomplishment (sādhanopāya), ${ }^{66}$ which are then enumerated

\footnotetext{
65 vande devam purānạ̣ śivam amaragurum bhūtalasthena mūrdhnā nityaṃ śāntam susūkșmaṃ tribhuvananamitam sarvasattvaikanātham | nịhsañgam nirvikāram prajananamaranakleśadoṣair vimuktam yogābhyāsaikavedyam trigunavirahitam naprasajyasvarūpam | nirvyāpāraṃ susūkșmaṃ kșitijaladahanākāśavātair vimuktam pratyakșādipramānaị kṛtibhir aviditam hetudrșțāntaśūnyam | rūpādīnām abhāvād avayavavikalād indriyair aprameyam pratyātmajñānagamyam pațubhir api girā nișprapañcasvabhāvam | The metre is sragdharā. This long Sanskrit syllabic metre was in use from the fourth century CE and was a particular favourite metre of Buddhists (Mitra 1989: 217 and 231). The only Śaiva label would be the word śiva, which can, however, merely be an adjective qualifying deva. It is thus doubtful that these two propitiatory stanzas were dedicated to Śiva. The OM NAMAY ŚIVĀYA that precedes these stanzas in all manuscripts was probably added at the time of the formation of the Nepalese corpus. The phraseology and terms such as pratyātmajñāna and nișprapañcasvabhāva point to early Mahāyāna Buddhism. This description could equally apply to the neutral Brahman.

${ }^{66}$ The Dharmaputrikā has three different acceptations of sādhana: 1) sādhanopāya, "means of accomplishment" refers to all the sixteen means leading to the accomplishment of yoga, as is clearly stated at the beginning: "Now, we will explain the specific denomination and the definition of the sixteen means of accomplishment" (atha sādhanopāyānām șodaśānām nāmanirdeśalakșanam vyākhyāsyāmah | DhPS 1.10ab), as well as at the end of the text: "Thus have been taught the sixteen means which lead to the accomplishment of the conjunction" (ity ete șodaśa proktā upāya yogasādhanāh | DhPS 16.24ab). 2) The second acceptation of sādhana serves to specifically name the
} 


\section{JOURNAL OF \\ YOGA STUDIES}

$2020 \cdot$ Volume 3

(1.4-10). As aforementioned, these sixteen means of accomplishment correspond exactly to the sixteen chapters of the Dharmaputrika, serving thus as a table of contents.

Then, the "Section on instrumental principles" (sādhanaprakaranam) proper begins, by listing the eight instrumental principles: 1) six ancillaries (sadanga); 2) six means (șadupāya); 3) six disciplines (șatsādhana); 4) four rules (caturyama); 5) two kinds of conjunction (dvirūpo yogah); 6) three methods of conjunction (trividho yogah); 7) ten impediments (daśopasarga); 8) eight qualities related to lordship (aștaiśvaryaguna). ${ }^{67}$ These eight instrumental principles are then described in detail.

1.1. The six ancillaries (șadanga) (1.13-29ab). These are: withdrawal (pratyāhāra), meditation (dhyāna), breath elongation (prānāyāma), fixation (dhāraṇa), discrimination (tarka), and samādhi.68

1.1.1. Withdrawal (pratyāhāra) is the retraction of the sense organs/faculties (indriya) from their objects by means of the mind (citta). The sense organs/faculties-the ears (karna), tongue (jihvā), skin (tvagindriya), nose (ghrāna), mind (manas), and eyes (nayana)-respectively withdraw from the sound (śabda), taste (rasa), the tangible (sprasțavya), smell (gandha), ideation (dharma), ${ }^{69}$ and the visible (drasțavya). The yogin must then "form a ball" and join this "ball" to the place (vastu) to be meditated on.70

first chapter, sādhanaprakaranam, "Section on the instrumental principles," which has eight subdivisions. According to Dharmaputrika 2.1 , these eight sādhanas aim at purifying the mind and the body before practising conjunction (aștabhị̣ sādhanair ebhiś cittam kāyaṃ ca yatnatah | śodhayitvā tato yogī yogābhyāsaṃ samācaret |). 3) In this first section, named sādhanaprakaranam, a third differentiated acceptation of sādhana occurs as a subdivision named șațādhana (DhPS 1.37cd-46ab, see below), rendered here as the "six disciplines."

67 The translation of aștaiśvaryaguna as the "eight qualities related to lordship" is based on indications found in the Mahābhārata, the Śivadharmottara, and early Purānic literature, that the eight yogic powers were conceived as qualities achieved by reaching eight levels governed by eight lords (iśvara). In other places, the text has also gunaiśvarya, used in the singular, simply rendered as "mastery of qualities." See Barois (forthcoming), "On a list of sixty-four gunas in Purāṇic literature."

${ }^{68}$ These six ancillaries are in the same order as in many Śaivasiddhānta texts and the Buddhist Guhyasamājatantra, though the latter has anusmrti in place of tarka (see Vasudeva, 2004: 378-79).

${ }^{69}$ This is a Buddhist conception of manas as being encompassed in citta and having dharma (in the singular), "mental conception, idea," as its object.

70 To form a ball (vartulikr-) means to aggregate internal bodily elements. The same image is also described in the context of the "operative channel" (kāryanāịi) (see below § 4.3.2), where it is clearly about gathering all the bodily winds into the heart. This image-"to form a ball"-is also found with a different wording in the Guhyasamājottara 147 (piṇ̣̂arūpa) and 154 (piṇdayoga) (see Sferra, 2000). 


\section{JOURNAL OF \\ YOGA STUDIES}

2020 - Volume 3

1.1.2. Meditation (dhyāna) is briefly defined as having four components: ${ }^{71} 1$ ) Siva is the one to be meditated upon (dheya); 2) the mind (manas) is the meditator (dhyātr); 3) meditation (dhyāna) is the thought focused on a single object (ekāgracittatā); 4) the purpose (prayojana) is cessation of suffering (duhkhahāni), mastery of the qualities (gunaiśvarya), and freedom (svātantrya).72

1.1.3. Breath elongation (prānāāāma) has four phases: inhalation (pūraka), retention (kumbhaka), exhalation (recaka), and a "quiescent" breath (praśānta). Definitions of the first three phases correspond to what is commonly found in yoga texts, with the additional indication that inhalation is carried out down to the base of the big toe. The phase named praśānta is defined as the moment when the body is empty of breath.73

1.1.4. Fixation (dhäranāa is defined as the penultimate phase of a series of temporal units of breath described as follows: a choti corresponds to the time needed to circle the knee (with the hand) three times; twelve choțis make a mātrā; a breath (prāna ${ }^{74}$ lasting twelve mātrās is called a breath elongation (prānāyāma); twelve breath elongations make a fixation (dhāranāa); twelve fixations make a mental concentration (yojanā); 75 twelve mental concentrations allow the conjunction (yoga) to be effected forthwith. ${ }^{76}$ The text concludes: these are the temporal measures of fixation (dhāranāvelāparimāna).

\footnotetext{
${ }^{71}$ On a textual parallel in the Śivadharmottara, see Introduction, p. $17 \mathrm{ff}$.

${ }^{72}$ Nowhere in the Dharmaputrikā is the notion of svātantrya explained or even mentioned again. I suggest there is a correspondence of this triple goal with the three fruits (phalatraya) described at the end of the Section on the path of meditation, dhyānamārgaprakaranam (see § 4.4).
}

73 On supraśānta/praśānta in early Śaiva and Buddhist Tantric works, see the overview by Goodall (2015: 491-493). A fourth phase is also mentioned in the Pātañjalayogaśāstra 2.51 without it being given a technical name. In the Dharmaputrikā, the short definition of the fourth phase as located in an "empty body" (DhPS 1.22: tucchadehe kșanam sthānam praśāntah so 'bhidhiyate |) and the occurrence of tucchadeha and praśānta in the context of the conquest of vyāna (DhPS 4.33: tucchadehe praśāntena ruddhvā vāyor gatāgatim | na pūrayen na recayed evam vyāno vijiyate |) suggest that praśänta refers to a time when there is no breathing. If this interpretation is correct, it would echo the Pātañjalayogaśāstra 2.51, where the fourth is defined as the absence of movement (gatyabhāva) of the two bodily winds prāna and apāna, which the Vivaraṇa ad Pātañjalayogaśāstra 2.51 confirms.

${ }^{74}$ Presumably, a breath cycle comprises all four phases as defined above $\$ 1.1 .3$.

75 yojana/yojanā is a doublet of yoga, meaning "conjunction" as well as "mental concentration." In the Dharmaputrikā, the neuter form yojana is also found in the compound dhäranāvamisayojana, the "joining of the succession of the fixation points," which is the third action (karman) expounded in chapter Four (see below $\S$ 4.3.3). A close acceptation of yojana is found in Śvetāśvatara Upanișad 1.10: kșaram pradhānam amrtākșaram harah kșarātmānāv iśate deva ekaḥ | tasyābhidhyānād yojanāt tattvabhāvād bhūyaś cānte viśvamāyānivrtttịh|. See also the use of dhārañāyojana in the late Amrtanāda Upanișad (also named Amrtabindu Upanișad), verse 23: tālamātrāvinișkampo dhāraṇāyojanam tathā | dvādaśamātro yogas tu kālato niyamah smṛtah |.

${ }^{76}$ Dharmaputrikā 1.24-25:

mātrādvādaśabhih prānah prānāyāma iti smrtah | 


\section{JOURNAL OF \\ YOGA STUDIES}

2020 - Volume 3

1.1.5. Discrimination (tarka) is defined as "reflection upon the investigation of the meaning established by the canonical treatises in various ways, upon the mutual disagreement amongst traditional teachings, and the question as to what is admissible or inadmissible, this reflection being effectuated by means of one's own thought conforming to logical argument (nyāyayukti), in order to decide: 'this must be considered, this must not."'77

1.1.6. Samādhi is defined as a state of equal consideration (tulyatva) for allies, neutrals, and enemies (mitrodāsinaśatru),78 and for wood, clay, or gold, as well as fondness (sneha) for all beings. 79

1.2. The six means (șadupāya) (1.29cd-37ab). These are: knowledge (jñāna), silence (mauna), chastity (brahmacarya), 80 being badly clad (durvāsa), restraint of the sense organs (indriyanigraha), and seclusion (aprādurbhāvana). 1) By way of definition of knowledge, the text states that the Veda, secondary [vedic] knowledge (upaveda), and ancillary [Vedic] disciplines (vedānga) are worldly (laukika) knowledge, while the method based on the established doctrine of the principles (tattvasiddhāntayoga) is supramundane knowledge (lokottara);81 2) silence is explained by the fact that speaking implies saying false (mithyā) as well as slanderous, pointless, and crude words (piśunasambhinna-pārusyavacana); 3) chastity is explained by the fact that sexual

prāṇāyāmair dvādaśabhir dhāraneti prakīrtitā|

dhāraṇābhir dvādaśabhir yojanā samudīitiā|

yojanābhir dvādaśabhir yogasamiñāā krtā purā |

Rather than a definition of dhārañā, this is a conception of dhāranā in terms of duration, in continuity with that of prānāyāma, "breath elongation." The Śivadharmottara 10.152 (W 124r, 1. 2-3) has a similar temporal definition of dhāraṇā (dhāraṇa dvādaśāyāmā dhyānam dvādaśadhāraṇam | dhyānaṃ dvādaśakam yāvan samādhir abhidhīyate |) as does the Vāyupurāna 11.21cd-22ab (tathā dvādaśamātras tu prānāyāmo vidhīyate | dhāraṇā dvādaśāyāmo yogo vai dhārañādvayam |) and the Mārkandeyapurāna 39.35cd-36ab (prāṇāyāmā daśa dvau ca dhārañā sābhidhīyate | dve dhäraṇe smrte yoge yogibhis tattvadṛștibhih |).

77 Dharmaputrikā 1.26cd-28ab: nānāprakārasiddhāntanișpannārthanirūpaṇe | āgamānyonyaviśliște heyopādeyasaṃśaye | ūhayitvā svacittena nyāyayuktyanusārin̄ā | idạ̣ grāhyam idaṃ neti chettuṃ tarko vidhìyate |

78 mitrodāsinaśatru is a formulaic expression (see for example Mahābhārata 2.5.14*0063_01 or Mānavadharmaśāstra 7.177 and 7.180).

${ }^{79}$ This definition of samādhi finds echoes in Bhagavadgītā 6.8-9, 12.18, 14.24-25, and Niśvāsatattvasaṃhitā, Nayasūtra 4.56-57b (see Goodall, 2015: 477). In chapter Sixteen of the Dharmaputrikā, samādhi is one of the four means of success (siddhyupāya) alongside renunciation of desires (sangatyāga), steadiness of mind (manahsthairya), and determination of the real (tattvanirnaya).

80 In the Dharmaputrikā, brahmacarya refers strictly to abstinence from sexual activity. In Pātañjalayogaśāstra 2.30, brahmacarya is one of the five rules (yama).

81 On Vedic knowledge considered as an inferior knowledge, see Mundaka Upanișad I.2 and 1.4. On the tattvas, see $\S 1.3$ below. 


\section{JOURNAL OF

relations with prohibited women (agamyanārī) and adultery obstruct the success of yoga or annihilate the level of success already attained; 4) being badly clad (durvāsa) is explained by the fact that beautiful clothes lead to desire (rāga), therefore an ochre (kāșāya) or despicable (kutsita) garment should be preferred;82 5) by way of definition of the restraint of the sense organs, it is stated that the sense organs located in the body are perpetually oppressive enemies (śatru), which is why they should be defeated before performing the conjunction (yoga); 6) seclusion (aprädurbhāvana) is the fact that the implementation of the conjunction (yogakriy $\bar{a}$ ) must not be effectuated in public. 83

1.3. The six disciplines (șațsādhana) (1.37cd-46ab). These are perseverance (utsāha), resolution (niścaya), constancy (dhairya), satisfaction (samtoșa), perception of principles (tattvadarśana), and cessation (upasamhāra) of sacrificial rites (kratu), described as follows:84 1) perseverance is faith in the repeated practice of conjunction (yogābhyāsa); 2) resolution consists in producing the thought (cittotpāda): "I will practise without fail;"85 3) constancy is an even mental disposition (manovrttitulyatā) with respect to success or failure;86 4) satisfaction is gladness (priti) whatever food and clothing is received;87 then, 5) perception of principles ${ }^{88}$ gives rise to a detailed description which mentions a group of three principles, ātmatattva, vidyātattva, and sivatattva, presented as

\footnotetext{
${ }^{82}$ A similar use of durvāsa/durvāsas is found in Mahābhārata 12.292.8: ekavāsāś ca durvāsāh śāyī nityam adhas tathā | maṇ̣̂ūkaśāyi ca tathā vīrāsanagatas tathā |. Kāsāāya commonly designates the yellow or ochre colour of the monastic robes of the Buddhists (see Wijayaratna 1990: 32 ff.). Natyaśăstra 21.132ab describes the garment of the wandering ascetics, sages, and Buddhists as being ochre (kāsāaya) (parivraṇmuniśākyānāṃ vāsaḥ kāṣāyam ișyate |). In Kauṇụinya's Bhāṣya ad Pāśupatasūtra 1.6, a brown-red garment is a distinctive mark of the religious mendicant (tathā bhikṣos tridaṇdamuṇ̣̂akamaṇdalukāṣāyavāsojalapavitrasthalapavitrādi lingam |).

${ }^{83}$ I suggest that the term yogakriya refers specifically to the actions (karman) to be implemented for the final phase of yoga, which involves death.

${ }^{84}$ On a textual parallel to this list in the Śivadharmottara and the Hațhapradīikika, see Introduction, pp. 20 and 32.

85 cittotpāda is a common technical Buddhist term meaning "production of intention, resolution." On the use of cittotpāda in early Mahāyāna Buddhism, see Sparham, 1987 and 1992.

${ }^{86}$ Compare Dharmaputrikā 1.39cd: siddhyasiddhyor manovrttitulyatā dhairyam ucyate |

with Bhagavadgitā 2.48:

yogasthạ̣ kuru karmāṇi sangaṃ tyaktvā dhanamjaya |

siddhyasiddhyoh samo bhūtvā samatvam yoga ucyate |

${ }^{87}$ In Pātañjalayogaśāstra 2.32, saṃtoșa is one of the five observances (niyama).

88 On the discussion about the mention of tattvadarśana in the Vivarana with regard to the question of the authorship of Śańkara, see Leggett (1992: 25) and Harimoto (2014: 234).
} 


\section{JOURNAL OF \\ YOGA STUDIES}

2020 - Volume 3

three aspects of knowledge, 89 then a list of twenty-five principles (tattva): the five elements (bhüta), the principle of individuation (ahaṃkāra), the subtle [principle] (sūkșma), the Ātman, the great [principle] (mahān), the group of eleven sense organs (indriya), and the five subtle elements (tanmātra);90 6) cessation of sacrificial rites is explained by the fact that the rites (dharma) performed by Vedic sacrificers (yājñika) bring pleasure (bhoga), power (aiśvarya), and wealth (dhana), and that they do not liberate from the cycle of rebirths since they are devoted solely to paradise (svarga). ${ }^{91}$

1.4. The four rules (caturyama) $(1.46 \mathrm{~cd}-53)$. Four rules for the daily routine are then mentioned:92 1) the rule related to time (velā): the only reasons for interrupting the practice of yoga are excretion of urine and feces (mūtravișthāsamutsarga) and intake of food (bhojana);93 2) the rule related to sleep (nidrā): a yogin sleeps during the two median

${ }^{89}$ The importance of these three principles as prerequisite knowledge is emphasized at the beginning of the text (DhPS 1.8). One might speculate that, since the Dharmaputrikā refers to a system with twenty-eight tattvas (see below § 4.1), the three tattvas could refer to those located beyond purusa, and therefore correspond to the last three entities among the five that constitute the bindu, namely Prabhu (which would be synonymous here with Ātman), Vidyā, and Śiva. This usage of prabhu meaning ātman occurs in Bhagavadgitā 5.14: na kartrtvaṃ na karmāni lokasya srjati prabhuh | na karmaphalasamyogam svabhāvas tu pravartate |, commented upon by Śankara as follows: na kartṛtvam svatah kurv iti nāpi karmāṇi rathaghațaprāsādādīnīpsitatamāni lokasya șjaty utpādayati prabhur ātmā |.

90 This list of twenty-five principles presents some variations compared to that of classical Sāmphya (Sāmkhyakārikā). It is close to certain Sāṃkhya configurations found in the Mokșadharmaparvan. A very similar list is also found in the Skandapurāna 181.1.

${ }^{91}$ Compare Dharmaputrikā 1.44cd-46ab:

yājñikair vihitā dharmā bhogaiśvaryadhanāvahāh |

svargamātraparā dharmā na tu saṃsāramocakāḥ |

bhogaiśvaryaprasaktānāṃ yogasiddhir na jāyate |

tadā hi tasmād yajñānām upasaṃhāra ișyate |

with Bhagavadgitā 2.43-44 (= MBh 6.24.43-44):

kāmātmānah svargaparā janmakarmaphalapradām |

kriyāviśeșabahulāṃ bhogaiśvaryagatiṃ prati |

bhogaiśvaryaprasaktānām tayāpahṛtacetasām |

vyavasāyātmikā buddhị samādhau na vidhìyate |

The first chapter of the Sivadharmaśāstra opens with a critique of the efficacy of the Vedic sacrifices, but with a view to propagating the "śivadharma": agnișțomādayo yajñā bahuvittakryānvitāḥ | nātyanta phalabhūyișțhā vahvāyāsasamanvitāh | na sakyante yatah kartum alpavitair dvijātibhih | sukhopāyam atno brūhi sarvakāmārthasādhakam | hitāya sarvasatvānāṃ śivadharmaṃ sanātanam | (Śivadharmaśāstra 1 [W 1v]).

92 Both the terms yama and niyama are used in this passage. These rules show a concern for the body and its natural needs. In this, they differ from the ethical rules (yama) and observances (niyama) in the Pātañjalayogaśāstra 2.30 and 2.32 .

${ }_{93}$ Similar prescriptions are found in the Mahābhārata, Mokșadharmaparvan 294.9: mūtrotsarge purīse ca bhojane ca narādhipa | trikālaṃ nābhiyuñjìta śeșaṃ yuñjita tatparaḥ|. 


\section{JOURNAL OF \\ YOGA STUDIES}

2020 - Volume 3

periods (yāma), but not during the first and the fourth periods;94 3) the rule for food (āhära): one must half fill his stomach (udara) with food, a quarter with water, the last quarter remaining empty;95 4) the rule for places (sthāna): this passage mentions the places that should be avoided: a pond, a tree dried by fire, an ant-hill, and a place infested with insects; and those appropriate for the conjunction: a lonely, calm place, at the foot of a tree, a place dedicated to gods, on the bank of a river, or in a house.

1.5. Two kinds of conjunction (dvirüpo yogah) (1.54-56ab). This two-verse passage mentions two kinds (dvirūpa) of conjunction: one related only to mind (mānasa), that is, without breath restraint (prānasaṃrodha), consisting in meditating upon a supreme subtle (principle) (paramam sūkșmam); the other being a "simultaneous" (yaugapadya) conjunction, which results from simultaneously restraining the bodily winds with manas, and manas with breath elongations (prānāyāma), while continuing to meditate on a supreme subtle principle. ${ }^{96}$

1.6. Three methods of conjunction (trividho yogah) (1.56cd-63ab). ${ }^{97}$ Continuing this long "Section on the instrumental principles" (sädhanaprakaranam), and corresponding to the sixth topic, the conjunction is defined as being triple: contracted (samkșipta), expanded (viśâla), and both contracted and expanded (dvikaranī). ${ }^{98}$ Contraction consists in meditating upon the entire universe and imagining all its components as being condensed in the supreme Ātman (paramātman), so that the world becomes empty and

${ }_{94}$ The night being generally divided into four periods of three hours, this would mean that the yogin's sleep lasts six hours. Similar prescriptions are also found in the Mahäbhärata, Mokșadharmaparvan 232.23, 180.28, 232.13, 294.13, and 313.44-45.

95 On a textual parallel with Śankara ad Bhagavadgitā 6.16, see Barois (forthcoming): "Śańkara the Yogin and the Dharmaputrikā Saṃhitā." These food recommendations are also found in classical medicine: Aștāngahrdayasaṃhitā, Sütrasthāna 8.46cd-47ab.

${ }^{96}$ See Dharmaputrikā 16.16-23, which describe the detailed procedure for the conjunction related solely to mind.

97 I use the term "method" because yogavidhi qualifies the contracted (saṃkșipta) procedure (DhPS 1.60ab) and yogasya vidhir, the dvikarani procedure (DhPS 1.63ab). It should be noted that the compound yogavidhi occurs in Kațha Upanișad 6.18.

${ }^{98}$ Compare Dharmaputrikā 1.56cd-57ab: sạ̣kșiptā prathamā jñeyā viśālā samanantaram | tato dvikaranī ceti trividho yoga ucyate |

with the Vivaraṇa ad Pātañjalayogaśāstra 1.40 (Śāstrī and Śāstrī 1952: 97): tatra sạ̣kșiptā viśâlā vikaraṇi ceti trayi dhāraṇā | tatrobhayakoțisparśinī vikaraṇi | paramamahatvāntasprg viśālā | paramāṇvantaspṛk saṃkșiptā | sā ca trayy apiha sūtropāttā \|40\|

The Vivarana has vikarañi, while the Dharmaputrika has dvikaranī. Furthermore, in the Vivarana the feminine is explained by the fact that it is a question of three dhāranās. Nothing seems to imply this in the text of the Dharmaputrikā and I have provisionally assumed that it is a question of three aspects (karani). On this issue, see Barois (forthcoming): "Śankkara the Yogin and the Dharmaputrikā Saṃhitā." 


\section{JOURNAL OF

only the supreme imperishable (paramākșara) remains. Expansion is the reverse process: from the fiery power (tejas) of Paramātman, an energy (śakti) emanates, followed by the series beginning with Sadāśiva, etc. ${ }^{99}$ The third method consists in meditating upon both resorption and emission (samhärasarga) of the universe by degrees.

1.7. Ten impediments (1.63cd-64ab). Ten impediments (upasarga) are then enumerated: hunger (kșudh), sleepiness (nidrā), idleness (ālasya), power (aiśvarya), pleasure (bhoga), fondness (sneha), wealth (dhana), fame (yaśas), rites (dharma), and knowledge (vidyā).100

1.8. Eight qualities related to lordship (1.64cd-74ab). In the last subdivision of the "Section on the instrumental principles," eight supernatural powers, named aiśvaryaguna, "qualities related to lordship," are characterized. These are: minuteness (animan), defined as the power of being imperceptible to the eye; lightness (laghiman), the ability to move through the sky; acquisition (prāpti), the ability to obtain any desired material object, as from the wish-fulfilling jewel (cintāmani); irresistible will (prākāmya), the ability to assume numerous ugly or charming bodies; majesty (mahiman), the power through which the yogin is honoured everywhere by gods, demons, and men; supremacy (iśitva), the power to command over all; subjugation (vasitva), through which the yogin is served by all creatures, these being infatuated by his beauty; the power to convert [something into its opposite] at will (yatrakāmāvasāyitā), which consists in the ability to go where pleasure (priti) is with the swiftness of thought and to cease it.101

\section{Chapter Two: "Section on postures," āsanaprakaraṇam (17 ślokas)}

The second subdivision of the yogaprakaranam provides us with one of the earliest systematic detailed descriptions of eight postures: the lotus posture (padmāsana), svastika posture (svastikāsana), throne posture (pịthāsana), mound posture (sthalāsana),

\footnotetext{
${ }^{99}$ This is the only mention of Sadāśiva in the Dharmaputrikā (DhPS 1.61):

tasya tejasi nirjātām śaktim yogād vicintayet |

sadāśivādīn tān sarvān paripātyā carasthitān |

It should be noted that Sadāśiva is here conceived as being contained in the Paramātman.

100 In Pātañjalayogaśāstra 3.36-37, upasarga designates the six obstacles to samādhi which are also perfections with regard to the rising up (vyutthāna). In the Dharmaputrikā, these latter are named antarāya and described in chapter Eight: "Obstacles such as intuitive knowledge, etc.," prātibhādyantarāyah.

101 On the difficulty of interpretation of yatrakāmāvasāyitā, see Brunner (1977: 508, note 14) and Vācaspati Miśra ad Pātañjalayogaśāstra 3.45 .
} 
joined-hands posture (añjalikāsana), half-moon posture (ardhacandrāsana), staff posture (dand̄āsana), and the all-auspicious posture (sarvatobhadrāsana).102

\section{Chapter Three: "Section on the succession of fixations," dhārañāvamiśaprakaraṇam (11 ślokas)}

The third subdivision of the yogaprakaranam is termed dhäranāvamísa, vamśa expressing the metaphor of the body as a bamboo cane. This chapter enumerates a succession of twenty-eight joints (parvan) from the big toe to the world of Brahmā: 1) big toe (añguștha); 2) foot (pāda); 3) heel (pārșni); 4) ankle (gulpha); 5) shank (janghōa); 6) knee (jānu); 7) thigh (ūru); 8) anus (pāyu); 9) generative organ (upastha); 10) navel (nābhi); 11) heart (manas); 12) chest (uras); 13) throat (kantha); 14) tongue (jihvā); 15) nostril (nāsikā); 16) eye (cakșus); 17) forehead (lalāta); 18) skull (mūrdhan); 19) top [of the head] (uparisțāt); 20) flame (arci); 21) beyond the body (paradeha);103 22) interior of the island (dvīpāntara);104 23) lower region (pātāla); 24) heaven on Earth (bhūsvarga); 25) heaven (svarga); 26) world of the Sun (süryaloka); 27) world of the Moon (somaloka); 28) world of Brahmā (brahmaloka). ${ }^{105}$

This chapter concludes that one must meditate upon/visualise the Ātman, also named the individual soul (jiva) and the drop (bindu), on each of these twenty-eight joints, one by one, once the bodily winds (prāna) have been suppressed.106

\footnotetext{
102 A first translation of this chapter has been published online: ayuryog.org/blog/eight-yoga-posturesdharmaputrikā (accessed on: December 12, 2020). Although lists of eight postures are common in Śaiva literature, there is no exact correspondence to the eight postures of the Dharmaputrika in other texts. The closest list is the one given by Kauṇịnya ad Pāśupatasūtra 1.16: tasmād upasprósya padmakasvastikopasthāñjalikārdhacandrapițhakadandāayatasarvatobhadrādīnām |. The Sarvajñānottaratantra, Yogapāda, has also a very similar list of seven postures:

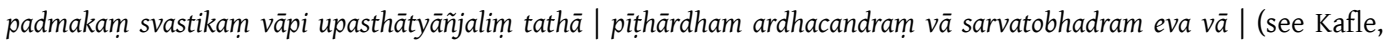
2015: 270). The descriptions of the svastika, ardhacandra, añjalika, danda, and pița postures are quoted in the late Hațhayoga tradition: the Yogacintāmaṇi of Godāvaramiśra, the Yogacintāmaṇi of Śivānandasarasvatī (1927: 153), and the Yogasiddhāntacandrikā of Nārāyanatīrtha (2000: 109-111) (see above, "Reception of the Dharmaputrikā teaching in the Hațhayoga tradition," p. 30 ff.).

103 paradeha could possibly be rendered as "another person's body," with reference to the level, on the vertical axis, corresponding to the entry into someone else’s body (a corpse) (see below § 4.4.2, parapuramjaya).

104 dvīpāntara, "interior of the island," probably corresponds to what is named lokāntara, "other world, distant world," in the context of the "ascent up to dissolution" (pralayotkrānti) (see § 4.3.5).

105 The names of the regions beyond the body (paradeha, dvīpāntara, pātāla, bhūsvarga, svarga, sūryaloka, somaloka, and brahmaloka) are already found in older texts, the Mahābhärata and some Upanișads, and none of these names is specific to Śaivism.

106 These two conclusive verses (DhPS 3.10-11: așțāvimiśati parvāṇi samyag jñātvā vicakșaṇaḥ| teșu parvasu sarveșu ekaikasmin krameṇa tu | tatra sthitam jīvabhūtam àtmānaṃ bindusạ̣jñitạ̣ | prāṇān yasmin nirudhyeta tatra bindum
} 


\section{JOURNAL OF \\ YOGA STUDIES}

2020 - Volume 3

\section{Chapter Four: "Section on the path of meditation," dhyānamārgaprakaraṇam} (88 ślokas)

The fourth and last section on yoga (yogaprakaranam) consists of a long chapter devoted to the "path of meditation" with eighteen subdivisions: five objects of meditation (pañcadhyeya), five conquests (pañcajaya), 107 five actions (pañcakarman), and three fruits (phalatraya) of yoga.

4.1. The five objects of meditation (pañcadhyeya) (4.2-15). First, it is indicated that a lotus is to be meditated upon (= visualised), at the beginning of the process of the conjunction (yogakrama) as well as at the time of the practice of the conquest (jayäbhyāsa). ${ }^{108}$ This lotus in the heart (hrtpadma) is then described, each of its parts being homologized with a virtuous disposition: its pericarp (karnika) corresponds to resolution (dhrti); its stalk (nāla) corresponds to non-violence (ahimssa)); its filaments (keśara) correspond to dharma; its eight petals (patra) correspond to eight good kinds of conduct (śila), i.e., not stealing, etc. (asteyādi, the detailed list is not mentioned).109

In the centre of this lotus is the supreme god (paramo devah) named bindu, also known as jiva, ${ }^{110}$ which comprises the five objects of meditation: Prakrti, Puruṣa, Prabhu, Vidyā, and Śiva, placed inside one another in concentric circles.111 Each of these aspects is

vicintayet |) are key to the understanding of the yogic process.

107 Some manuscripts examined have pañcajapa, which is undoubtedly wrong.

${ }^{108}$ In the context of the meditation on a lotus in the heart, again the correctness of jayābhyāsa is not in doubt (rather than japäbhyāsa): this refers to the meditation on a lotus mentioned in the context of the conquest of the very subtle obstacle (mahāsūkșmāntarāya), that is, imminence of death made evident through its portents.

${ }^{109}$ The concept of the heart lotus dates from the oldest Upanișads. In the Dharmaputrikā, the parts of the lotus are not homologized with dharma, jñāna, vairāgya, and aiśvarya, as in the Sivadharmottara. In terms of structure, the heart lotus in the Dharmaputrikā seems closer to that described in the Niśvāsakärikā (see Goodall, 2011: 233-38 and 240-42).

110 In the context of the description of the antarātman, a similar metaphor of a drop (bindu) on a heart-lotus is found in the Mahābhārata, Śāntiparvan 180.23: ātmānam tam vijānīhi sarvalokahitātmakam | tasmin yah saṃśrito dehe hy abbindur iva pușkare |. In the context of the description of the elementary soul, bhütātman, a similar metaphor is found in Maitrāyanīya Upanișad 3.2: athāsti tasyātmā bindur iva pușkara iti (van Buitenen, 1962: 102). In this passage of the Upanișad, it is specified that the bindu is subdivided into five tanmātra and/or gross elements (bhūta).

111 In the Śaiva Niśvāsakārikā, the lotus in the heart is also surmounted by five concentric discs, but homologized with other entities, namely: Sun, Moon, Fire, Sadāśiva, and Śiva (see Goodall, 2011: 240-42). In the Dharmaputrikā, Sadassiva is included in the bindu, that is to say, in the individuated form of Brahman that resides in the body. These five objects of meditation and the way they are arranged in concentric circles might be an archaic version of the system consisting of five kalās in the developed Śaivasiddhānta. The configuration of the bindu in the Dharmaputrikā could explain why there are only four kalās in the Niśvāsatattvasaṃhitā, Nayasūtra $3.72 \mathrm{ff}$., namely the four kalās plus Śiva, a structure which was then normalized with five kalās forming the bindu in the classical Śaivasiddhānta. 


\section{JOURNAL OF \\ YOGA STUDIES}

2020 - Volume 3

assigned a particular radiance and a rank in the series of tattvas: Prakrti, the twentyfourth principle, has the radiance of the sun (sürya) and is placed above the pericarp; Purușa, the twenty-fifth principle, has the radiance of the moon (candra) and is placed in the middle of the orb of the sun; Prabhu, the twenty-sixth principle, has the radiance of the flame of the fire (hutāśärci, vahnijvālā) and is placed in the middle of the orb of the moon; Vidyā, the twenty-seventh principle, has the radiance of crystal (sphäțika) and is placed in the middle of the orb of the fire; Siva, the twenty-eighth principle, has the radiance of ether (ambara) and is placed in the middle of the orb of Vidyā.112 This passage concludes with two important details that clarify the link between the bindu and the breath: bindu must be meditated upon at the precise place where the breath (niśvāsa) is held; the jivva (= bindu) goes to the place that is filled with the bodily winds (prāna). ${ }^{113}$

4.2. The five conquests (pañcajaya) (4.16-38). The five conquests refer to the conquest of the five bodily winds. They are named-prāna, apāna, samāna, udāna, and vyāna-114 then the method to overcome them one by one is explained.

The conquest of prāna involves the entire body on its vertical axis. It consists in accomplishing all four phases of prānāyāma (see § 1.1.3.), followed by the fixations performed one after another along the succession of the twenty-eight joints from the big toe (see chapter Three). Unlike the conquest of prāna, the conquest of the other bodily winds is accomplished through partial breathing practices that involve particular parts of the body: the conquest of apāna consists of an inhalation (pürana), then a fixation followed by the setting in motion of the wind apana, which is situated in

${ }_{112}$ The number of twenty-eight tattvas also corresponds to the number of the joints from the big toe to the world of Brahmā detailed in chapter Three (dhārañāvamiśaprakarañam), but the correspondence is not explicitly formulated.

113 This statement is consistent with Dharmaputrikā 3.10-11.

The Buddhist Amrtasiddhi (eleventh century) appears to have a close conception of bindu as connected with breath. Compare Dharmaputrikā 4.15:

dhāryate yatra niśvāsas tatra bindum vicintayet |

yo deśạ pūryate prānair jīvas tam yāti nānyathā |

with Amrtasiddhi 7.6:

vāyunā sādhyate bindur na cānyad bindusādhanam |

yām avasthāṃ vrajed vāyur bindus tām eva gacchati $\mid$

114 They are listed without any explanation, even etymological, of their bodily functions, contrary to what is commonly found: the Niśvāsatattvasaṃhitā, Nayasūtra 4.122-125 describes in detail the physiological function of the five winds, as does the Mrgendrāgama, Vidyāpāda 22-27, which describes the functions of the five winds on the basis of etymological definitions; the Vivaraṇa ad Pātañjalayogaśāstra 3.93 also describes the functions of the five winds on the basis of etymological definitions; the Vāyaviyasaṃhitā 2.29.36-41ab describes the physiological function of the ten winds. 


\section{JOURNAL OF

the lower part of the body, with manas; the conquest of samanna is to stop outward and downward breathing (gatāgati, in lieu of prāna and apāna) with a retention (kumbhaka), followed with a fixation in the heart; the conquest of udāna consists in holding the wind as before, 115 then moving the wind upwards with manas; the conquest of vyanna requires the stopping of outward and downward breathing with a quiescent breath (praśānta) in an empty body (tucchadeha) in such a way that there is no inhalation or exhalation.

Two distinct categories of signs (lakșana) that attest to the conquest of each bodily wind are indicated. These correspond to two distinct levels of the practice of the conjunction, namely moderate practice (abhyāsa) and intense practice (atyabhyāsa), each level having a distinct effect on the body: moderate practice improves health, intense practice causes diseases. For example, the first signs of the conquest of apāna is that no more humoral alteration (dosa) is produced: the yogin does not suffer pain due to the restraint of flatus, urine, and excrement, and he even becomes capable of having control over his excretions. Then, once diseases such as fistula (bhagamdara), etc., are produced by intense practice (atyabhyāsa), this is the sign of victory over apāna. The description of the conquest of each of the other bodily winds follows the same pattern specifying the beneficial effects of moderate practice and the morbid effects of intense practice. ${ }^{116}$

The concluding passage on the conquest of the bodily winds teaches that the most important is the repeated exercise of the conquest of prāna, because all bodily winds are conquered by the mere conquest of prāna.117 It is also specified that the five conquests have been expounded in order to differentiate between actions (karmavibhāgārtham), a reference to the five actions (pañcakarman, see below $\S 4.3$ ), the implementation of which requires knowledge of the partial breathing practices in particular bodily parts.

4.3. The five actions (pañcakarman) (4.39-80). The technical term pañcakarman relates to specific breathing practices carried out after the bodily winds have been conquered. It is clearly specified that an action performed with an unconquered wind gives rise to diseases (doșa). The five actions are: 1) the purification of the channels (nādīsodhana);

\footnotetext{
115 That is, as for the conquest of apāna.

116 It seems that the moderate level of practice indicates which bodily wind is conquered according to positive symptoms of health improvement, and that the manifestation of diseases is the conquest itself. This apparently paradoxical description is explained by a two-step conception of the process of conjunction, the second step being an intensification of the practice at the signs of imminent success (this is described in chapter Thirteen, vrddhyupāyah, "Means of increasing") which implies abandonment of the body, without it being explicitly formulated.

117 The primacy of prāna over the other bodily winds is also taught in Niśvāsatattvasamhitā, Nayasūtra 4.130: "It is prāna that he should conquer first; once prāna is conquered, the mind is conquered; once the mind is conquered the soul is calmed [...], [and] ultimate reality shines [before it]" (Goodall, 2015: 497-98).
} 


\section{JOURNAL OF \\ YOGA STUDIES}

2020 - Volume 3

2) the operative channel (käryanādì); 3) the joining of the succession of fixations (dharanavamśayojana); 4) the upwards exhalation (udrecanī); 5) the ascent up to dissolution (pralayotkrānti).118

4.3.1. The purification of the channels (nädiśsodhana). ${ }^{119}$ Three different methods are described: 1) the use of the bodily wind prāna only; 2) the use of different bodily winds, depending on the part of the body concerned: samanna for the middle part of the body, apanna for the lower part (from the big toe upwards), and udanna for the upper part; 3) repeated practice of alternate breathing: blocking of the right nostril, inhalation through the left nostril, holding of the breath, and then exhalation through the right nostril (with the metaphor of breath movements as bellows). 120

4.3.2. The second action, named "operative channel" (kāryanādì), appears to consist in a preparatory recognition or an initial implementation of the channel to serve for the effectuation of the next three actions (karman).121 With an utterance of the syllable OM, it consists in forcibly (hathād)122 dragging upwards the bodily winds (prāna) located in the lower parts of the body, gathering them in the heart, and then holding them here in the form of a ball.123 Then, with another utterance of OM, it consists in raising the bodily winds up to the skull (kapālānta), holding them here for a while, drawing them

\footnotetext{
${ }^{118}$ These actions are to be understood as five stages of the ascent of the soul up to the going-out of the body and beyond, the key locations in the body being provided by the list of the successive fixations (dhāranāvamśa) given in chapter Three.

119 The purification of the channels is succinctly explained in Niśvāsatattvasamhitā, Nayasūtra 4.110: avasavyena pūreta savyenaiva tu recayet | nādīisamśsodhanam hy etan mokșamārgapathasya tu |. According to the Dharmaputrikā, the purification of the channels is a practice that is not strictly equated to the prānāyāma itself. Rather, it is a specific combination of breathing practices using the fourfold prānāyāma as a structural basis.

120 A metaphor of the blacksmith's bellows is found as early as in the Majjhima Nikāya, Mahāsaccaka Sutta, of the Pāli Buddhist canon: "Just as when an extremely strong noise comes about when the bellows of a smith are blown, just so indeed, Aggivessana, there came about the extremely strong noise of winds which went out through the ears, when my breathing out and breathing in had been stopped both through the mouth and through the nose" (transl. Bronkhorst, 1993: 7). In a similar context as in the Dharmaputrika, the metaphor of breath movements as bellows (drvivat) is also found in the Śivadharmottara to explain pūraka (ŚDhUt 10 [W 122r]: bāhyena vāyunā dehan dṛtivat pürayet bhrísam | tathāpürnah santiștheta püranāt püra[na]kah smṛtah |). This verse of the Śivadharmottara was borrowed by the Vāyavìyasaṃhitā (VāSa 2.29.24: bāhyena marutā deham dṛtivat paripūrayet | nāsāpuțenāpareṇa pūraṇāt pūrakam matam |).
}

121 kāryanādī is a hapax legomenon that probably refers to technical knowledge.

122 In the context of the pañcakarman, the term hatha occurs twice, in close connection with the dragging upwards winds "forcibly": first in the context of kāryanādị: hațhād ākarșayet prāṇān adhobhāge vyavasthitān| DhPS 4.47cd; second in the context of udrecani, where it is explained that the yogin must not forcibly perform this technique, so as to avoid causing pain or affliction (kheda): bahuvāram na kurvita kramayogena bhedayet | hațhasādhyam na kartavyam akhedenaiva sādhayet | DhPS 4.61.

${ }_{123}$ See above, note 70 . 


\section{JOURNAL OF \\ YOGA STUDIES}

2020 - Volume 3

downwards by the same path, and placing them again in the heart. Then the yogin must exhale gently through both nostrils.

4.3.3. The "joining of the succession of fixations" (dhäranāvamśayojana) is an action using the entire vertical axis of the twenty-eight joints of the body detailed in chapter Three (dhārañavamśaprakaranam). It consists in drawing upwards gradually, with the syllable OM, the bodily winds situated at each joint, beginning with the big toe, on the flow path of the channels (nädīsamcāramārga). After meditating upon each joint respectively and holding (presumably) the bodily winds in each joint successively, one must constrict all (winds) that are situated in the limbs (śākhā) and place them in the heart. In a second step and in the same manner, the yogin must draw upwards and then hold the bodily winds in the chest, the throat, the tongue, the nostrils, the eyes, the forehead, and the skull successively, and then move them downwards again. Once the bodily winds are established in the heart, the yogin must exhale gently. By the daily practice of these exercises, the channel becomes fit for action (kāryakșama).

4.3.4. The fourth action, "upwards exhalation" (udrecanī), is said to be secret. Channels that have not been mentioned before are named for the first time: idā, which is linked to the left nostril, susumna ${ }^{124}$ presumedly linked to the right nostril, and a channel or place simply called "the fourth," turyā, at the centre of the eyebrows. ${ }^{125}$ It is stated that the breath that has gone out of the two channels (id̄a and susumnā) is called the "bond to life" (bhavabandhana), and that the going-out through the "fourth" brings about the fruits of yoga. Then the practice is described: the upwards exhalation consists in closing the nine bodily apertures with manas and entering into the "fourth" by uttering a long sound (OM). The yogin must practise two or three times a day, until he has established the path of yoga in his head (svamastaka). He must not practise many times nor forcibly (hațhat) pierce, but rather follow the progressive way, so that no pain will occur. Once the yogin has reached the "fourth," he again draws the breath downwards and holds it in the heart. Then, issuing out by the same path, he must reach little by little the top of the head (upariștāt) and the tip of smoke rising from the flame (arcidhūmaśikhā).126

\footnotetext{
124 This schema differs from the basic model of sușumnā as the central channel, with iḍā on the left side and pingalā on the right side. In the same way as the Dharmaputrikā, the Niśvasatattvasaṃhitā, Uttarasūtra 5.37 mentions only these two channels, suṣumnā and iḍ̄a (see Goodall, 2015: 33 and 397).

125 See Maitrāyaṇiya 6.19: ... turyākhye dhārayet prānam ity |, “[...] he must maintain his prāna in that which is called turyä" (see van Buitenen, 1962: 142).

126 The flame (arci), a location beyond the body on the axis of the dhāranāvamía, seems to correspond, in terms of practice, to the fire of conjunction (yogägni) which appears at the time of the increasing of the practice in chapter Thirteen.
} 


\section{JOURNAL OF \\ YOGA STUDIES}

2020 - Volume 3

4.3.5. The fifth and last action, named "ascent up to dissolution" (pralayotkrānti), is the stage which corresponds to the abandonment of the body. ${ }^{127}$ After constant repetition of the fourth action (udrecani) and given that death is expected, the examination of the foreshadowings of death (arista) in one's own body is carried out. ${ }^{128}$ When a foreshadowing of death is perceived, the abandonment of one's body is undertaken. First, the five bodily winds called nāga, krkara, kürma, devadatta, and dhanañjaya are altered:129 a strong breath in is the sign of the alteration, or more particularly degradation, of nagga; following the piercing of the vital points (marman), the leaving of the bodily winds (prāna) from all joints one by one indicates the alteration of krkara; once all the bodily winds in the limbs are gathered in the heart, their progression upwards is the sign of the alteration of kürma; a rale in the throat while the body is immobile indicates the alteration of devadatta; finally, when dhanañjaya is altered, the individual soul (jiva) attains the other world (lokāntara) after it has abandoned the body.

From there, the individual soul yoked to its virtuous and non-virtuous fruits reaches the eight joints from paradeha to brahmaloka. ${ }^{130}$ An archery metaphor is then used to illustrate the method:131 the yogin must be determined to join the target that shines in the middle. In the same way as a bowman aims at the target with his sight (drsți), the yogin trains to meditate upon paradeha, etc. with his mind (citta, manas). Then he does the same while uttering a long sound followed by uninterrupted resonance (= OM). Once he has reached the target with only one utterance, he simultaneously sets in motion the (vital) breaths. In the same way that a bowman who has mastered the target (jitalaksya) kills with only one arrow, he who has mastered yoga (jitayoga) must exert

\footnotetext{
127 The translation of utkrānti as "yogic suicide" should be reconsidered, since the term "suicide" means exactly the opposite of what is at stake in ancient yoga: it is not a matter of killing oneself (suicide, from the Latin sui "of oneself," formed after homicide), on the contrary, it is about preserving one's own self, which is the individual proper. The ascent (utkrānti) that allows for the leaving of one's own body is a technical method of control over one's own life that has a positive connotation.

128 This is an implicit reference to chapter Six (see below).

129 To my knowledge, this is one of the earliest references to the role of the five winds in the biological process of death. For this passage, I propose vikurvate to have a passive sense, and consider that it is the bodily winds that are altered. Goodall (2015: 497), quoting these verses of the Dharmaputrikā (DhPS 4.68-73) in his commentary ad Nayasūtra 4.129, understands them differently, namely that the winds alter the body, on the basis of the variant vikärakah in the Nepalese edition (1998).

130 That is to say, the eight located beyond the flame (arci) and named in ascending order: paradeha, dvipantara, pātāla, bhūsvarga, svarga, sūryaloka, somaloka, brahmaloka. See chapter Three (dhāraṇāvaṃśaprakaranam).

131 This metaphor is further elaborated in chapter Sixteen of the Dharmaputrikā (see below), in a context that also corresponds to a level beyond the body, specifically related to liberation (mokșa). A similar archery metaphor is also found in the Mundaka Upanișad 2.2.3-6, and more importantly in the Maitrāyaniyya Upanișad 6.24, whose formulation is closer to that of the Dharmaputrika. I recently presented this material at the conference "Paths to
} 


\section{JOURNAL OF \\ YOGA STUDIES}

$2020 \cdot$ Volume 3

himself with only one sound. Having thus abandoned his body, he obtains the fruit of yoga.

4.4. The three fruits of the conjunction (yogaphalatraya) are then described (4.81-88):

1) mastery of qualities (gunaiśvarya); 2) conquest of another body (parapuramjaya);

3) liberation (mokșa).132

4.4.1. The eight qualities related to lordship (aștaiśvaryaguna) have already been characterized (see $\S 1.8$ ). This passage is intended as an explanation of the method for mastering qualities (gunaiśvarya): after the yogin has meditated with manas on the quality that he desires among the eight (i.e., animan, etc.), he must abandon his body in order to unite with this quality, and then be reborn, it being understood that he now possesses the chosen quality. 133

4.4.2. Parapuramjaya is the "conquest of another citadel," that is, of another body. A yogin afflicted with old age who wishes to abandon his body must search for a corpse provided with all its limbs, born in a good lineage, and handsome; he must meditate upon this corpse with manas and proceed with the aforementioned conjunction (yoga). It is pointed out that this fruit makes it possible to avoid childhood and the suffering due to the stay in the womb.134

4.4.3. Liberation (mokșa) is called the spotless fruit (nairañjanam phalam) and described as the attainment of the supreme Brahman, qualified as imperishable (avyaya) and the end of all suffering (sarvaduhkhānta). It occurs when the yogin abandons his body while the mind has no support (nirāśraya), and relies solely on knowledge (jñānamātrāvalambin). ${ }^{135}$

\footnotetext{
Liberation in the Hindu and Sikh Traditions," organized by C. Pecchia, M. Rastelli, and V. Eltschinger, at the Institute for the Cultural and Intellectual History of Asia, Austrian Academy of Sciences (November 28-29, 2019), under the title: "Mārga in the Dharmaputrikā Saṃhitā: From the Path of the Bodily Winds to the Archery Metaphor."

${ }^{132}$ They are ranked from one to three, which seems to correlate with successive levels in the series of fixations (dhāraṇāvamiśa, see chapter Three).

${ }^{133}$ To my knowledge, there is no other text that explains this method of acquiring yogic powers. The statement deham parityajet probably means that the yogin dies.

134 On the suffering condition of the foetus in the Hindu tradition, see Barois (2021).

135 On the method of attaining liberation, see chapter Sixteen.
} 


\section{JOURNAL OF \\ YOGA STUDIES}

$2020 \cdot$ Volume 3

\section{Chapter Five: "Subtle obstacles," sūkṣmāntarāyaḥ (5 ślokas)}

At first, the four kinds of obstacles (antarāya, vighna) arising while the yogin is performing the conjunction are mentioned by name: subtle obstacles (sūkșmāntarāya), very subtle obstacles (mahāsūkșmāntarāya), obstacles through negligence (pramādajāntarāya), obstacles such as intuitive knowledge, etc. (prātibhādyantarāya), with the important specification that there are two ways to treat them: conquest (over the bodily winds) (jaya) and medical treatment (cikitsā). Then, the subtle obstacles are listed: friendship (mitra), wealth (lakșmī), property (dhana), women (kāntā), and teacherdisciple relationships (śisyopādhyāyabāndhava). They are defined as fetters due to emotional attachment (snehapāśa), enjoyment of worldly objects (vișayāsvāda), and the desire to be happy (sukhepsu). Also named as subtle feelings (sūkșmabhāva), they cause distraction (vyākșepakāraka) of the mind and become obstacles to success (siddhi). ${ }^{136}$

\section{Chapter Six: "Very subtle obstacles," mahāsūkșmāntarāyaḥ (28 ślokas)}

This chapter introduces the very subtle obstacles, that is, the bodily and mental phenomena heralding imminent death. At first, it is indicated that one should not be afraid or abandon practice at the approach of death, but rather undertake quickly that which has to be done (a reference to the five actions described above, see $\S 4.3$ ).137 Then, two kinds of foreshadowing of death (arișta) are described: 1) external (bāhya): the time left to live is inferred from visual hallucination, dreams, or symptoms of bodily disintegration (teeth falling out, black tongue);138 2) internal (adhyātmika): the time remaining to live is inferred from the number of days during which a slowness/ weakness (māndya) takes place in one channel (sușumnā or id̄a).139 This chapter concludes that the yogin undertakes the remedy (pratikära) for the foreshadowings of death he has perceived.

\footnotetext{
136 The question of the distractions (vyākșepa) of mind is also addressed in chapter Sixteen of the Dharmaputrikā. The Śivadharmottara 10 (W 124r) conveys a laconic Śaiva version of the same idea: evam dhyānasamāyuktah svadeham yah parityajet | kulasvajanamitrāni samuddhrtya śivo bhavet |.

${ }^{137}$ Fear of death is one of the five afflictions (kleśa) in Pātañjalayogaśāstra 2.3.

${ }^{138}$ Numerous parallels to these verses on the ariștas are found in the Vāyupurāṇa 19, the Mārkandeyapurāna 43 and the Lingapurāna 1.91.

139 I know of only one parallel passage to these ädhyātmika foreshadowings of death in the Yogaśāstra of Hemacandra (twelfth century). Its chapter Five is essentially devoted to various processes of divination, including a category of foreshadowings of death also called adhyātmaka, "internal", ascertained according to "the movement of the breath in the arteries” (see Qvarnström, 2012: 184-197).
} 


\section{JOURNAL OF \\ YOGA STUDIES}

2020 - Volume 3

Chapter Seven: "Obstacles through negligence," pramādajāntarāyah (8 ślokas)

Obstacles through negligence are defined as obstacles that arise in the course of the conquest of the five bodily winds, when they are drawn upwards following the succession of fixations (dhäraña), in order to spring out of the upper orifice. At the time of the yoga process, relying on an unconquered place in the body through carelessness causes diseases. The names of the diseases thus produced are given: abdominal swelling (vātagulma), retention of feces (udāvarta), shortness of breath (ūrdhvaśvāsa), vomiting (chardi), diarrhoea (atīsāra), confusion (moha), exhaustion (klama), fainting (mūrchā), dizziness (bhrama), violent headache (śirahśūla), heart palpitations (hṛllāsa), hiccups

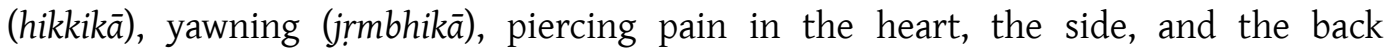
(hrtpārśvaprșțhaśūla), wind blood disease, generally rendered as gout or rheumatism (vātarakta), eye disease (timira), swelling (śvayathu), skin disease (kuștha), and fever (jvara).

\section{Chapter Eight: "Obstacles such as intuitive knowledge, etc.," prātibhādyantarāyaḥ (6 ślokas)}

The term pratibhādi refers to a list of six obstacles (antarāya) that affect the yogin who has accomplished conjunction (präptayoga). The first three obstacles are: intuitive knowledge (prātibha), supernatural hearing (śrāvana), and supernatural visual perception (ādarśa). The other three are supernatural touch, smell, and taste (sparśagandharasa) relating to earth (pärthiva), intermediate space (antarīssaga), and heaven (divya). ${ }^{140}$ He who abandons the power (śakti) which proceeds from these obstacles and, being absorbed in Brahman (brahmapara), is yoked, he is released from them. ${ }^{141}$

\section{Chapter Nine: "Conquest," jayah (19 ślokas)}

The chapter named jaya explains how to overcome the subtle and very subtle obstacles which have been detailed in chapter Five and Six, respectively.

\footnotetext{
${ }^{140}$ This tripartition goes back to early Vedic texts (see Rgveda 6.22.8, 7.104.2, and 10.53.5).

${ }^{141}$ The category of obstacles named prātibhädi concerns a level beyond the body at the time of the fifth and last action, "ascent up to dissolution" (pralayotkrānti). The last verse of chapter Ten prescribes an intensification of the practice when these obstacles appear (see below). That is to say that, at this very advanced stage of the yoga process, no specific remedy for this category of obstacles is indicated, rather an intensification of the practice, which is explained further in chapter Thirteen.
} 


\section{JOURNAL OF \\ YOGA STUDIES}

$2020 \cdot$ Volume 3

The first verse states that an ignorant person (ajñānin) practicing conjunction sees sins or diseases (doșa) developing, therefore it is only after having devoted oneself to knowledge (jñānapara) that one proceeds to the conjunction.

9.1. Conquest of the subtle obstacles (9.2-11) entails the abandonment of worldy attachment (āsakti). It proceeds from an inquiry into the origin and nature of the body, conceived as an aggregate (pinda) produced from desire (samkalpa) due to the maturation of the previous acts (pürvakarmavipāka). The body is called an aggregate of six sheaths (șațkauśikam pindam), ${ }^{142}$ namely marrow, bones, nerves, flesh (or muscle), and blood, enclosed in skin, and described as filled with saliva, mucus, brain, feces, urine, full of ill-smelling worms, identical with ordures in burial places, etc. ${ }^{143}$ It is impure, transient, affected by birth, death, old age, and various diseases (roga). It is afflicted by cold and heat (śitoșna), hunger and thirst (kșutpipāsa), etc. That which is external to this aggregate of six sheaths is called atman. The passage concludes that whoever conceives of the body in this way conquers the subtle obstacles, and that the one who is free from worldly attachment (nihsanga), deprived of sins or diseases (doșa), and exempt from the manifold mental conceptions (vikalpa) is called paramātman.

9.2. Then, the remedial procedure (pratikāra) to the very subtle obstacle (9.12-19), namely great fear (mahäbhaya) due to the imminence of death, is explained: the yogin meditates upon god, that is, the bindu (bindudeva) located in the middle of the lotus of the heart, and then visualizes above an uninterrupted flow of nectar (sudhādhārā) moving down into the region of the uvula (ghanțikā). Through this juice of nectar (amrtarasa), contentment of the self (ätmatrpti) is produced. ${ }^{144}$ Two different procedures involving the use of mantras are then described: 1) The recitation of the ten-syllable mantra that conquers death (mrtyuñjaya) accompanied with the three-syllable mantra that has NETRA as the seed-syllable (netrabija);145 2) the combination (samputa) of

\footnotetext{
142 The conception of the body as an aggregate of six sheaths is common, as noted by Meulenbeld (1999-2002, vol. IIB: 45, note 335): "P.V. Sharma [...] points to the term șațkośa as being of Buddhist origin (74; garbhāvakrānti 10: some consider the body to be șațkośa); this term is, however, also current in, for example, Sāṃkhya philosophical (see E. Frauwallner, 1953: 364) and Tantric works (see D. Heiligers-Seelen, 1994: 66)."

143 This description aiming at producing disgust for the body recalls the Buddhist meditation on the impure (aśubhabhāvanā) and the meditation on the body (kāyagatā sati). Kritzer (2014) discusses this in the context of the Garbhāvakrāntisūtra, then in an article devoted to meditation on the impure: "Aśubhabhāvanā in Vibhāṣā and Śrāvakabhümi" (2017).

144 It seems that trpti is conceived as the opposite of fear.

145 Pending further research, it should be noted that in the Netratantra, OM JUM SAH is the mantra NETRA, also called mrtyuñjaya, "dont les trois syllabes sont souvent (mais pas ici) mises en correspondance avec les trois yeux que le Mantra totalise" (Brunner, 1974: 132). In the Dharmaputrikā, no specific Śaiva feature appears.
} 


\section{JOURNAL OF \\ YOGA STUDIES}

2020 - Volume 3

eighty-one words (ekāsítipada) with nine tattvas (navatattva), which are not specified.146 Then, the intake of an elixir (rasāyanopayoga), the gift (dāna) of one's own possessions, and the performance of one hundred thousand oblations (lakșahoma) with tender leaves of the mango tree and dūrvā grass, etc. (āmrapallavadūrvādi) ${ }^{147}$ are prescribed. By means of this procedure, the yogin is no longer prey to fear or joy (priti) and intensifies his practice of the conjunction (yogābhyāsa). ${ }^{148}$

\section{Chapter Ten: "Medical treatment," cikitsā (24 ślokas)149}

In response to chapter Seven on obstacles through negligence (pramādajāntarāyah), chapter Ten explains how to overcome the humoral alteration (doșa) induced when the wind is sent on the wrong path and a knot (granthi) occurs. At first, the respective locations of the three humours in the body are indicated as follows: wind (vāta) occupies the region from the sole of the foot up to the navel, bile (pitta) occupies the region from the navel up to the heart, phlegm (śleșman) occupies the upper part of the body, a distribution consistent with classical medicine (Carakasamhitā 1.20.8; Suśrutasamhitā 1.21.6). Then diseases that are produced when the wind is blocked in the receptacle of bile (pittakost tha = from the navel to the heart region) are named, and the treatment indicated: rubbing with oil (tailäbhyanga), bathing with hot water, and eating food prepared with milk (pāyasa) and accompanied by clarified butter. The text specifies that the conjunction (yoga) should be undertaken at the end of digestion. The part of the treatment specifically dedicated to yogic practices is then described. In each place of the body where an illness causes suffering, a meditation with the mind (manas) upon the wind situated at the place of suffering is prescribed, followed by repetitive inhalations (püraka) and exhalations (recaka).150 A procedure that follows the same

\footnotetext{
${ }^{146}$ The mantra in eighty-one words (ekāsítipada) is called vyomavyāpin in the Śaiva tradition, but this term does not occur in the Dharmaputrikā. Goodall \& Isaacson (2016: 6, note 15) indicate that "the earliest known Śaiva mälāmantra is the vyomavyāpimantra." With regard to the navatattvas, a few details are provided in the Tāntrikābhidhānakośa (2013: vol. 3, 52), with reference to the Niśvasatatttvasaṃhitā, Uttarasūtra 1.4-14 (see Goodall 2015: 339-441), but in the Dharmaputrikā, there is no mention of navātman as in the Uttarasūtra. See also Niśvāsatattvasaṃhitā, Nayasūtra 1.15-28 (Goodall, 2015: 405-6).

${ }_{147}$ This is the only mention of ritual practices in the Dharmaputrikā.

148 On the intensification, see chapter Thirteen named "Means of increasing" (vrddhyupāyah).

149 This chapter on medical treatment was borrowed in its entirety from the Dharmaputrika and attributed to the Hathapradipikā in some late manuscripts of this text. See Introduction, p. 32.

150 Compare Dharmaputrikā 10.9:

yasmin yasmin samuddeśe rujā bādhā pravartate |

tasmin deśe sthitaṃ vāyuṃ manasā paricintayet |

with Vāyupurāna 11.46cd-47ab (Caturvedī \& Simha, 1995):
} 


\section{JOURNAL OF

general pattern but differs in detail (i.e., different breathing practices involving kumbhaka or a complete prānāyāma) is prescribed for cases where the wind is blocked in the region of phlegm (kaphakoștha) as well as for other diseases (not related to a humoral region in an obvious way). A large number of the diseases treated in this chapter correspond to those mentioned in the list given in chapter Seven. ${ }^{151}$ This chapter also refers to authoritative medical knowledge (vaidyaśāstra). It concludes that the yogin must intensify his yoga practice (yogäbhyāsa) when the obstacles named prātibhādi appear.

\section{Chapter Eleven: "Transient signs," calalingaḥ (10 ślokas)}

This chapter marks a new explanatory step for the practice of the conjunction, after the four kinds of obstacle have been overcome by both methods of conquest (jaya) and/or medical treatment (cikitsā) (these topics are addressed in chapters Five to Ten).

At this level, an activity (pravrtti) indicating the advent of success (siddhi) occurs in the body. The yogin feels a spontaneous and unprecedented sensation (sparśa), such as a crawling sensation (pipilikāgati, literally "ants walking"), ${ }^{152}$ the tongue salivating and other sensations similar to those caused by poison, fire, or thorns (vișägnikantaka). He must acknowledge this activity as being the fire of conjunction (yogāgni), which causes the destruction of his sins ( $p \bar{a} p a)$ and thus heralds the success of conjunction. Transient signs (calalinga) of success consisting in the extrasensory (amānușa) perception of sounds, tastes, senses of touch, forms, and smells are then detailed.

yasmin yasmin rajo deśe tasmin yukto vinirdiśet |

yogotpannasya vighnasya idam kuryāc cikitsitam |

and Mārkaṇ̣̂eyapurāna 39.57cd-58ab (Banerjea, 1862):

yasmin yasmin rujā dehe tasmims tadupakārin̄im |

dhārayed dhāraṇām uṣne sítām śîte ca dāhinīm |

These verses are issued from two parallel passages on medical treatment (cikitsā) in the context of yoga in the Vāyupurāna and Mārkaṇdeyapurāna, these passages being in both texts difficult to grasp. To these must be added a parallel in the Śivadharmottara 10 (W 122v): yasmin yasmin bhaved deśe yoginām vyādhisambhavaḥ| tattadangam dhiyā vyāpya dhārayet tatra dhāraṇām |

151 These diseases also correspond in part to those mentioned in the case of intense practice, that is, the critical moment from life to death, within the context of the conquest of the five bodily winds (pañcajaya) (see $§ 4.2)$.

152 Mention of a crawling sensation is also found in a yoga context in the Mārkandeyapurāna 42.6 and the Niśvāsatattvasaṃhitā, Nayasūtra 4.19. 


\section{JOURNAL OF \\ YOGA STUDIES}

$2020 \cdot$ Volume 3

\section{Chapter Twelve: "Lasting signs," dhruvalingah (4 ślokas)}

In pursuance of the foregoing, this short chapter names the lasting signs (dhruvalinga) of success: freedom from disease (ārogya), bodily agility (laghudehatva), smoothness of skin (tvaksnigdha), shiny complexion (śubhavarnatā), charming speech (manojñäbhāșitā), wisdom (prajñ̄a) , etc. 153

\section{Chapter Thirteen: "Means of increasing," vrddhyupāyah (6 ślokas)}

This chapter describes briefly how the yogin who has perceived only a little of the fire of conjunction (yogāgni) must then intensify this fire of conjunction through constant repeated practice (abhyāsa). This intensification is illustrated by an extended metaphor in four verses: 1) just as smoke attests to the production of fire by friction, a sensation (sparśa) testifies to the production of the fire of conjunction (this topic being covered in chapter Eleven); 2) in the same way as a flickering fire is produced by friction, the fire of conjunction is fanned through exertion (yatna); 3) just as a flaming fire is intensified by the combustibles (indhana) that are grass and wood, the fire of conjunction is intensified by the combustibles that are the six ancillaries, etc.;154 4) a flaming fire destroys the combustibles gradually in the same way as the fire of conjunction, blazing up, burns former sins (pāpa). The chapter concludes that obtaining the fruit of conjunction stems from the destruction of sins in this way.

153 These phenomena occurring when conjunction is imminent echo the description in the Śvetāśvatara Upanișad 2.11-13:

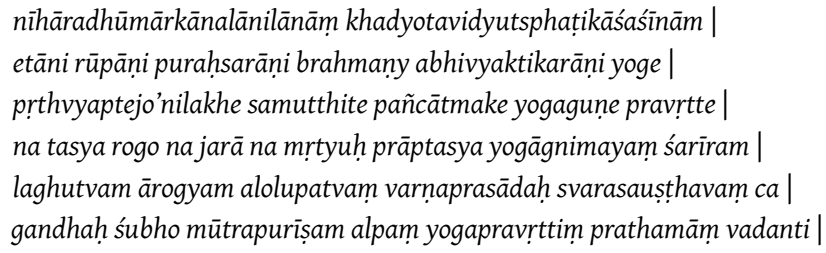

154 This passage documents the yogic practice with regard to the role of the six ancillaries, etc. (șadangādi), which are characterized in chapter One. The Dharmaputrikā clearly distinguishes a level of repetitive practice (abhyāsa) which involves both the breath and manas, and a level which only involves manas (on this level without support, nirāśraya, see $\S 4.4 .3$ and chapter Sixteen) and is the ultimate level leading to liberation. This distinction between two levels of practice is summarized in the definition of the two kinds of conjunction (DhPS 1.54-56ab, see § 1.5). It appears that the six ancillaries are practices related to the first level of practice (involving both the breath and manas). These details, accessible thanks to the precise descriptions and internal coherence of the Dharmaputrika, give access to new elements of understanding. For example, in light of the Dharmaputrikā, it seems to me that it would now be possible to understand Niśvāsatattvasaṃhitā, Nayasūtra 4.24: șadangadhyānavarjitam to mean "without [the level of] meditation based on the six ancillaries," rather than "which is beyond six-limbed yoga," to qualify a visualization practice called nirālamba (see Goodall, 2015: 471). 


\section{JOURNAL OF \\ YOGA STUDIES}

$2020 \cdot$ Volume 3

\section{Chapter Fourteen: "Loss," vināśah (3 ślokas)}

Three behaviours that cause the loss of this level are indicated: the prattling with others (due to extreme joy), the abandonment of yogic practice (due to the fact that the yogin thinks he has obtained success), and the slandering of the master (guru).

\section{Chapter Fifteen: "Recovery," pratyānayanam (12 ślokas)}

Chapter Fifteen describes three means (upāya) to restore an activity (pravrtti) 155 which had appeared or even increased, and which have been destroyed, presumably because of one of the three behaviours described in the preceding chapter. The issue is to recover the level previously attained and to complete the process of conjunction in its terminal stage. The appropriate places to operate this restoration are mentioned (the bank of a river, a forest, a secret place, an empty house, and a silent, solitary, peaceful place). Then the three means are described:

1) After devoting himself to the means of success (siddhyupāya), 156 the yogin must focus his mind (manas) on the big toe and then slowly restrain the bodily winds (prāna) until the sensation (sparśa) (which indicates activity) disappears. This involves impelling this sensation upwards while uttering the sound (=OM). 2) Or, the tip of the tongue being placed on the two rows of teeth, the yogin must do a breath elongation (prānāyāma) until the sensation (sparśa) (which indicates activity) disappears. Since the feeling of the fire of conjunction (yogägni) always occurs through the tip of the tongue, this involves rapidly impelling this sensation upwards, as before. 3) Or, the yogin must focus his mind at the centre of his palate (tālu), and restrain the breath. Once the activity (pravrtti) is produced, he must draw this sensation upwards again, as before.

The chapter concludes with a few verses that summarize the process: The yogin must focus his mind (manas) anywhere in the body where activities were previously produced and then restrain the bodily winds (prāna). There is no purification of the sins (pappaśodhana) equivalent to the breath elongation, which is why the knower of the conjunction performs the conjunction (yuñjita yogavit) after he has engaged in breath elongation. The yogin whose self is purified through breath elongation (prānāyāmaviśuddhātman) is freed from all sins. He sees in the (individual) self (ātman) the immaculate light of the (supreme) self (ätmajyotis). Or, after he has drawn upward

\footnotetext{
155 The activity (pravrtti) indicating the advent of success and the sensation (sparśa) which attests to it are detailed in chapter Eleven.

156 On the means of success (siddhyupāya), see chapter Sixteen.
} 


\section{JOURNAL OF \\ YOGA STUDIES}

2020 - Volume 3

(manas) alone (kevalam) to the level of the skull as a result of conjunction (yoga), he sees the (individual) self fastened to the (supreme) self as a pearl threaded on a string. ${ }^{157}$

\section{Chapter Sixteen: "Means of success," siddhyupāyah (27 ślokas)}

The last chapter of the Dharmaputrikā deals with different topics successively. At the beginning, it is stated that one can proceed to actions (karman, see $\S 4.3$.) only when one knows the means of success (siddhyupayya). 158 Then the rules concerning the seated and standing postures 159 as well as bodily arrangements and upper-body postures ${ }^{160}$ are defined as causes of distraction (vyāksepajanaka), the sole cause of success (siddhihetu) being: renunciation of desire (sangatyāga), steadiness of mind (manahsthairya), samädhi, and the determination of the real (tattvanirnaya). 161 This topic is elaborated on in a few verses.

Then a metaphor explaining practice is explained: the target is Siva, the bow is the body, the string is the sound ( $n \bar{a} d a=O M$ ), the arrow is the mind, and the yogin must define what must be pierced/penetrated by means of the intellect (buddhi). ${ }^{162}$ It is only

157 This ancient metaphor (Jaiminiya Upanișad Brāhmaṇa 1.18.8; Śāinkhāyanāraṇyaka 11.8.2 and 12.7.3) is also found in Mahāohārata 12.199 in a similar context: yadā te pañcabhih pañca vimuktā manasā saha | atha tad drakșyase brahma manau sūtram ivārpitam |

158 The metaphor for the imminence of success (DhPS 16.1): hastatale siddhir vartate, "success stands on his palms," is also found in Vin̄āśikhatantra 333 (Goudriaan, 1985: 83).

159 sthānāsana has several occurrences in the Mānavadharmaśāstra. Olivelle notes ad Mānavadharmaśāstra 6.22: "spend the day standing and the night seated: surprisingly, no commentator or translator has understood the correct meaning of the technical expression sthānāsanābhyām viharet. It refers to a religious observance during which the person has to remain standing during the day (without sitting down) and seated during the night (without lying down)." This technical term is also used in the context of the definition of tapas in the Bhāssya ad Yogasūtra 2.32.

160 samsthāna occurs with the meaning of bodily arrangement in the Tattvavaiśāradī ad Yogasūtra 2.46. karana carries the meaning of "upper-body posture," as Kafle (2015: 270 and note 766) specifies.

161 Compare Dharmaputrikā 16.2-3:

sthānāsanavidhānāni sạ̣sthānakaraṇāni ca|

vyākșepajanakāḥ sarve na hy ete siddhihetavaḥ |

sangatyāgo manahsthairyam samādhis tattvanirṇayaḥ |

siddhihetur bhavanty ete śeșā vyākșepakārakāḥ |

with the Vivaraṇa ad Pātañjalayogaśāstra 2.29 (Śāstrī and Śāstrī, 1952: 212):

yad anyatrocyate - sthānāsanavidhānāni yogasya vidhayo'pi vā | vyākșepajanakāh sarve na te yogasya hetavah | sarvadoșaparityāgah samādhiś ceti taddvayam | nirṇaya[yāt] yogahetuh syād bhavati vānyan na vā [bhavatv anyan na vā bhavet] |

Thus, this quotation in the Vivarana, hitherto unidentified, is from the Dharmaputrikā.

162 This archery metaphor as a device for teaching how to perform the ascent beyond the body has already been mentioned at the end of the explanation on the five actions (pañcakarman) (see above $\$ 4.3 .5$, and note 131). 


\section{JOURNAL OF \\ YOGA STUDIES}

2020 - Volume 3

with a mind (citta = manas, compared to an arrow) that has given up desire that the yogin obtains the fruit of conjunction. The metaphor continues by being integrated into a detailed explanation of the practice: the yogin performs an inhalation (püraka = the hand) in order to fill his body (deha = the bow), then he scrutinizes the bindu (= the target) by means of the sight of the intellect (buddhidrsți), he raises upwards the bindu that stands in the body (deha = the bow) filled with sound ( $n \bar{a} d a=$ the string), and he shoots the mind (manas = the arrow) supported by breath (prāna) into the middle of the target.

The recipients of the teaching of the Dharmaputrika are then named, attesting that the technique for the conjunction expounded here is accessible to all castes and stages of life: "Whether he is a householder, a brahmacārin, a hermit, or an ascetic, the one who has renounced all desires obtains liberation, even if he is engaged in his own activities (svakarman). [Liberation] is obtained by [those] who know the conjunction through actions (karmayogajña), [whether they are] women, śüdras, householders, foreigners, low castes: in this case, birth is not a criterion." 163 Then, in continuity with the abovementioned, it is stated that the conjunction can be conducted while continuing one's own activities: whether he stands, walks, sleeps, or eats or is even engaged in activity, the karmayogin does not miss the target with his mind (citta) only. ${ }^{164} \mathrm{He}$ must maintain

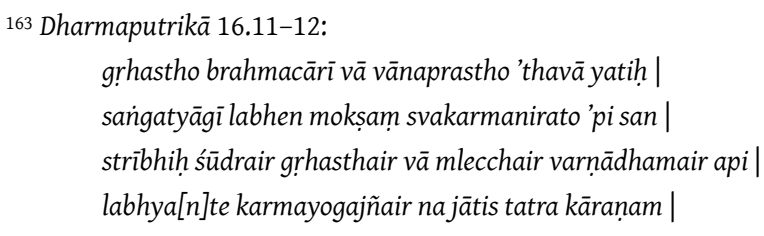

The interpretation of this passage requires further research. As labhyante has no obvious subject here, I suggest reading labhyate, referring to mokșa in the previous verse, pending the consultation of other manuscripts. It should also be noted that the list grhastha brahmacārin, vānaprastha, and yati corresponds to that of the Baudhāyanagrhyaparibhāșāsūtra. On this list, Lubin (2016: 600) comments: “The inclusion of brahmacarya suggests familiarity with Manu's system, and the fact that the fourth is called the yati probably means that this passage is no later than Manu; later Dharmaśāstras introduce the term saṃnyāsin."

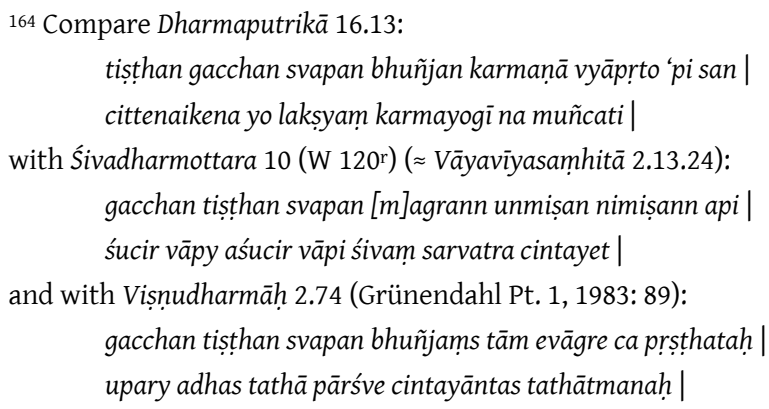

The term karmayogin does not appear in the Śivadharmottara and the Viṣnudharmāh.

Could we possibly find a distant echo here of the Mahāsatipațhāna-Sutta DN 22.4 on the four postures (walking, standing, sitting, and lying down)? 


\section{JOURNAL OF \\ YOGA STUDIES}

2020 - Volume 3

his breaths with manas, as well as manas with breath elongations (prānāyāma), then he must meditate on the supreme Brahman.

Then an obscure and corrupted verse seems to relate to meditation on the supreme Brahman, and to refer to the placing or arrangement (vinyāsa) of the angamantras, and brahmamantras, and to the mantra HAMSA. 165

Following this, it is stated that when the yogin is exhausted due to the practice of prānāyāma, he must undertake the conjunction related solely to mind (kevalam mānasam yogam). ${ }^{166} \mathrm{He}$ must do this with a mantra-repetition (japa) or a story (kathā) ${ }^{167}$ related to it, so that the mind is not empty (śünya). This passage describes in detail, without it being explicitly formulated, the method which leads to liberation (moksa).168 Essentially it consists of withdrawing oneself from perception by purifying (viśudh-) the mind (citta), the key issue being to remove the cause (hetu) responsible for the cognitions related to pleasure and pain, etc. (sukhaduhkhädibuddhi), so that there is no more mental representation for the isolated mind. 169

In the concluding verses, it is recalled that this text was composed by Sanaka, with the supplementary information that it was written down by the son of Dharmaśila. ${ }^{170}$

\footnotetext{
165 Dharmaputrikā 16.15: dïrghāny añgāni vinyāsaṃ hrasvaṃ vaktram tathaiva ca | haṃsa haṃseti yo varnạm varjayet [sic] paramam padam | This interpretation is deduced from the fact that the bijäkșaras of the angamantras are always long, whereas the bijas of the brahmamantras are always short (see Brunner, 1963: xxxiv). However, this question requires further research, possibly with reference to close passages in Niśvāsasamhitā, Uttarasūtra 3.23, and Sarvajñānottara 2 (see Goodall, 2015: 371).

166 See the definition of the two kinds of conjunction (dvirūpo yogah) in chapter One (§ 1.5).

167 As for the mention of kathā as an alternative to japa, Padoux (1987: 119) notices that the Mokșadharmaparvan (MBh 12.189-193) "définit le japa comme la récitation d'un texte védique utile (japet vai samhitām hitām) - sans d'ailleurs préciser quel texte - et le pose par rapport au Sāmphya et au Yoga." Bühnemann (1988) devotes a few pages to kathā in the context of the vratas, where it is a question of listening and not of enunciating: "After the performance of the püja part of a vrata often a story connected with this vrata is read aloud. These stories narrate the revelation of the vrata by a seer or a deity, its first performance, results, and procedure. By listening to them the devotee takes part in the events of bygone times and induces the power which effected beneficial results formerly to do the same for him now." (Bühnemann, 1988: 196). See also Śivasūtra 3.27: kathā japah̆, an essentialised version of what may have been a real alternative formerly.

168 See the definition of liberation (mokșa) at the end of chapter Four (§ 4.4.3).

169 Dharmaputrikā 16:22cd: nirāśrayasya cittasya vikalpo naiva vidyate |.

170 See Introduction, p. 12.
} 


\section{Synoptic Table of the Structure of the Dharmaputrikā Samnhitā}

The names of the sixteen "means of accomplishment" (sädhanopāya) are given in the second column. The first column indicates the structural groupings of chapters specified in the text. In the third column, some significant thematic sub-subdivisions of these chapters are mentioned.

\section{Sixteen chapters corresponding to sixteen "means of accomplishment" (sädhanopāya)}

\begin{tabular}{|c|c|}
\hline $\begin{array}{l}\text { Chapter One: "Section on the } \\
\text { instrumental principles," } \\
\text { sādhanaprakaranam }\end{array}$ & 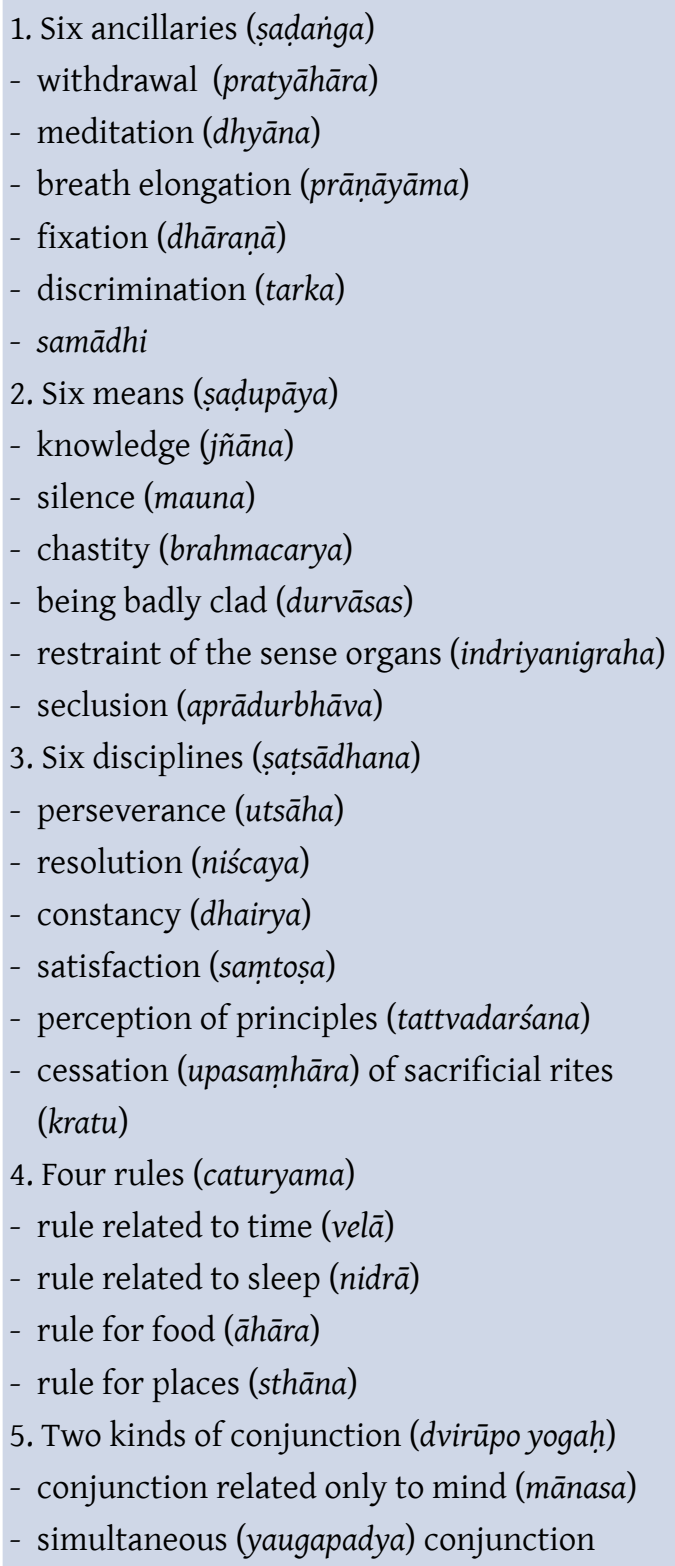 \\
\hline
\end{tabular}




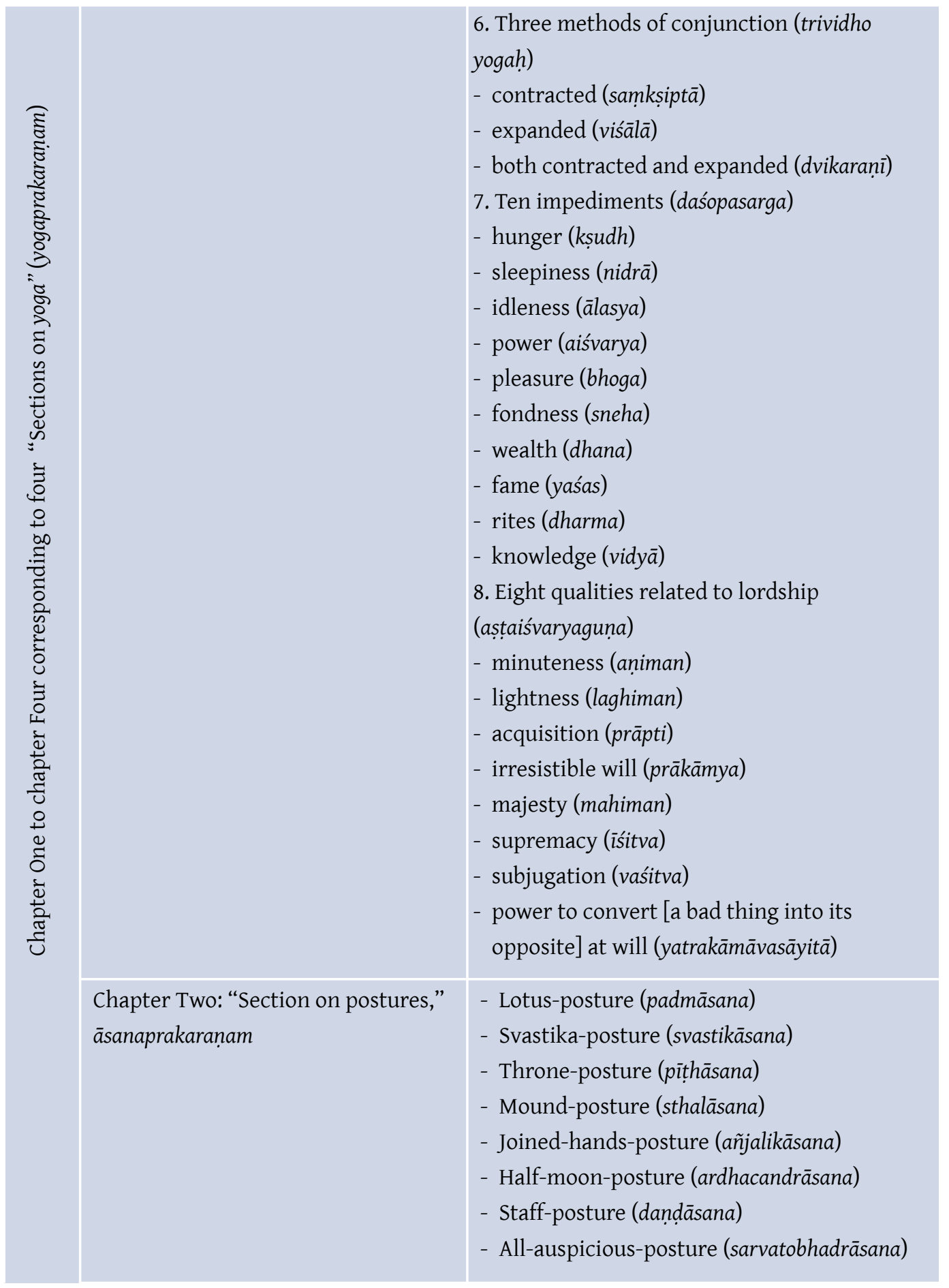




\begin{tabular}{|c|c|}
\hline $\begin{array}{l}\text { Chapter Three: "Section on the } \\
\text { succession of fixations," } \\
\text { dhāranāvamśaprakaranam }\end{array}$ & $\begin{array}{l}\text { Twenty-eight joints (parvan): } \\
\text { 1- big toe (angusțha) } \\
\text { 2- foot (pāda) } \\
\text { 3- heel (pārșni) } \\
\text { 4- ankle (gulpha) } \\
\text { 5- shank (jañghā) } \\
\text { 6- knee (jānu) } \\
\text { 7- thigh (ūru) } \\
\text { 8- anus (pāyu) } \\
\text { 9- generative organ (upastha) } \\
\text { 10- navel (nābhi) } \\
\text { 11- heart (manas) } \\
\text { 12- chest (uras) } \\
\text { 13- throat (kanthha) } \\
\text { 14- tongue (jihvā) } \\
\text { 15- nostril (nāsikā) } \\
\text { 16- eye (cakșus) } \\
\text { 17- forehead (lalāta) } \\
\text { 18- skull (mūrdhan) } \\
\text { 19- top [of the head] (upariștāt) } \\
\text { 20- flame (arci) } \\
\text { 21- beyond the body (paradeha) } \\
\text { 22- interior of the island (dvīpāntara) } \\
\text { 23- lower region (pātāla) } \\
\text { 24- heaven on Earth (bhūsvarga) } \\
\text { 25- heaven (svarga) } \\
\text { 26- world of the Sun (sūryaloka) } \\
\text { 27- world of the Moon (somaloka) } \\
\text { 28- world of Brahmā (brahmaloka) }\end{array}$ \\
\hline $\begin{array}{l}\text { Chapter Four: "Section on the path } \\
\text { of meditation," } \\
\text { dhyānamārgaprakaranam }\end{array}$ & $\begin{array}{l}\text { Five objects of meditation (pañcadhyeya) } \\
\text { - Prakṛti } \\
\text { - Purușa } \\
\text { - Prabhu } \\
\text { - Vidyā } \\
\text { - Śiva } \\
\text { Five conquests (pañcajaya) } \\
\text { - conquest of prāna (prānajaya) } \\
\text { - conquest of apāna (apānajaya) }\end{array}$ \\
\hline
\end{tabular}




\begin{tabular}{|c|c|c|}
\hline & & $\begin{array}{l}\text { - conquest of samāna (samānajaya) } \\
\text { - conquest of udāna (udānajaya) } \\
\text { - conquest of vyāna (vyānajaya) } \\
\text { Five actions (pañcakarma) } \\
\text { - purification of channels (nādīisodhana) } \\
\text { - operative channel (kāryanāḍ̄) } \\
\text { - joining of the succession of fixations } \\
\text { (dhāranāvamśayojana) } \\
\text { - upwards exhalation (udrecanī) } \\
\text { - ascent up to the dissolution (pralayotkrānti) } \\
\text { Three fruits of the conjunction } \\
\text { (yogaphalatraya) } \\
\text { - eight qualities related to lordship } \\
\text { (gunaiśvarya) } \\
\text { - conquest of another body parapuramjaya) } \\
\text { - liberation (mokșa) }\end{array}$ \\
\hline 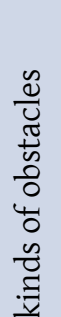 & $\begin{array}{l}\text { Chapter Five: "Subtle obstacles," } \\
\text { sūkșmāntarāyah }\end{array}$ & $\begin{array}{l}\text { - friendship (mitra) } \\
\text { - wealth (lakșmī) } \\
\text { - property (dhana) } \\
\text { - women (kāntā) } \\
\text { - teacher-disciple relationships } \\
\text { (śisyopādhyāyabāndhu) }\end{array}$ \\
\hline 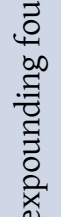 & $\begin{array}{l}\text { Chapter Six: "Very subtle obstacles," } \\
\text { mahāsūkșmāntarāyaḥ }\end{array}$ & $\begin{array}{l}\text { - external foreshadowing of death } \\
\text { (bāhyārișța) } \\
\text { - internal foreshadowing of death } \\
\text { (ādhyātmikārișța) }\end{array}$ \\
\hline 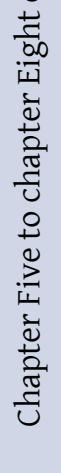 & $\begin{array}{l}\text { Chapter Seven: “Obstacles through } \\
\text { negligence," pramādajāntarāyah }\end{array}$ & $\begin{array}{l}\text { - abdominal swelling (vātagulma) } \\
\text { - retention of feces (udāvarta) } \\
\text { - shortness of breath (ūrdhvaśvāsa) } \\
\text { - vomiting (chardi) } \\
\text { - diarrhoea (atīsāra) } \\
\text { - confusion (moha) } \\
\text { - exhaustion (klama) } \\
\text { - fainting (mūrchā) } \\
\text { - dizziness (bhrama) }\end{array}$ \\
\hline
\end{tabular}




\section{YOGA STUDIES}

\begin{tabular}{|c|c|}
\hline & $\begin{array}{l}\text { - violent headache (śirahśūla) } \\
\text { - heart palpitations (hrillāsa) } \\
\text { - hiccups (hikkikā) } \\
\text { - yawning (jrmbhikā) } \\
\text { - piercing pain in the heart, the side, and the } \\
\text { back (hrtpārśvaprsțthaśüla) } \\
\text { - gout, rheumatism (vātarakta) } \\
\text { - eye disease (timira) } \\
\text { - swelling (śvayathu) } \\
\text { - skin disease (kuștha) } \\
\text { - fever (jvara) }\end{array}$ \\
\hline $\begin{array}{l}\text { Chapter Eight: "Obstacles such as } \\
\text { intuitive knowledge, etc.," } \\
\text { prātibhādyantarāyaḥ }\end{array}$ & $\begin{array}{l}\text { - intuitive knowledge (prātibha) } \\
\text { - supernatural hearing (śravana) } \\
\text { - supernatural visual perception (ādarśa) } \\
\text { - supernatural touch, smell, and taste } \\
\text { (sparśagandharasa) }\end{array}$ \\
\hline Chapter Nine: "Conquest," jayah & $\begin{array}{l}\text { - conquest of the subtle obstacles } \\
\text { (sūkșmāntarāyajaya) } \\
\text { - conquest of the very subtle obstacles } \\
\text { (mahāsūkșmāntarāyajaya) }\end{array}$ \\
\hline $\begin{array}{l}\text { Chapter Ten: "Medical treatment," } \\
\text { cikitsā }\end{array}$ & \\
\hline $\begin{array}{l}\text { Chapter Eleven: "Transient signs," } \\
\text { calalingah }\end{array}$ & \\
\hline $\begin{array}{l}\text { Chapter Twelve: "Lasting signs," } \\
\text { dhruvalingah. }\end{array}$ & \\
\hline $\begin{array}{l}\text { Chapter Thirteen: "Means of } \\
\text { increasing," vrddhyupāyah }\end{array}$ & \\
\hline Chapter Fourteen: "Loss," vināśah & \\
\hline $\begin{array}{l}\text { Chapter Fifteen: "Recovery," } \\
\text { pratyānayanam }\end{array}$ & \\
\hline $\begin{array}{l}\text { Chapter Sixteen: "Means of success," } \\
\text { siddhyupāyah. }\end{array}$ & \\
\hline
\end{tabular}




\section{JOURNAL OF \\ YOGA STUDIES}

2020 - Volume 3

\section{Acknowledgements}

This article was made possible through funding from the European Union's Horizon 2020 research and innovation programme under grant agreement No 639363. I address my heartfelt thanks for their comments and suggestions to Jason Birch, Matthew Clark, Philipp A. Maas, James Mallinson, Nina Mirnig, Marion Rastelli, Alexander Schiller, and Dagmar Wujastyk, as well as to the anonymous reviewers. I would also like to thank Anil Kumar Acharya and Nirajan Kafle for sharing with me an initial draft of a critical edition of the Dharmaputrika, as well as Suzanne Newcombe, who kindly provided me with the apograph of the Śivadharma corpus.

\section{References}

\section{Primary Sources}

Amṛtanāda Upanișad

Sastri, A. M. (ed.). 1920. The Yoga Upanishads with the commentary of Sri UpanishadBrahma-Yogin. Madras: Adyar Library.

Amṛtasiddhi

Mallinson, J. and Szántó, P. D. Amrtasiddhi. Draft edition/work in progress: May 9, 2019.

Așțāngahṛdayasaṃhitā

Srikantha Murthy, K. R. (text and transl.). 1991-95. Vāgbhața's Așțānga Hṛdayam (Text, English Translation, Notes, Appendix, and Indices). 3 vols. Varanasi: Krishnadas Academy.

Harišāstrī, P. V. (ed.). 1939. The Astāngahrịidaya, A Compendium of the Ayurvedic System composed by Vāgbhața, with the commentaries Sarvāngasundarā of Arunadatta, and Āyurvedarasāyana of Hemādri. Collated by ... Annā Moreśwar Kunte ... and Krisna Rāmchandra Śāstrī Navre. 6th ed. Bombay: Nirṇaya Sāgar Press.

Rgveda

Aufrecht, T. (ed.). 1877. Die Hymnen des Rigveda. Bonn: Adolph Marcus.

Kațha Upanișad

Renou, L. (ed., transl.). 1943. Kațha Upanishad. Paris : Adrien-Maisonneuve.

Radhakrishnan, S. (ed., intro., transl., and notes), 1992 (1953). “Kațha Upanișad.” In The Principal Upanișads. 5th print. Delhi, Bombay, Calcutta: Oxford University Press. 


\section{JOURNAL OF \\ YOGA STUDIES}

2020 - Volume 3

Carakasaṃhitā

Trikamji Ācārya, J. (ed.). 1941. The Charakasaṃhitā by Agniveśa, Revised by Charaka and Dridhabala, With the Āyurveda-Dīpikā Commentary of Chakrapānidatta (carakā, śrícakrapānidattaviracitayā āyurvedadīipikāvyākhyayā saṃvalitā). Edited by Vaidya Jādavaji Trikamji Āchārya. 3rd ed. Bombay: Nirṇaya Sāgar Press.

Sharma, P. V. (text and transl.). 1981-94. Caraka-Saṃhitā: Agniveśa's treatise refined and annotated by Caraka and redacted by Drdhabala (text with English translation). 4 vols. Varanasi: Chaukhambha Orientalia.

Sharma, R. K. \& Dash Vaidya B. (text and transl.). 1976-2002. Agniveśa's Caraka Saṃhitā (Text with English Translation and Critical Exposition Based on Cakrapāni Datta's Āyurveda Dipikā). 7 vols. Varanasi: Chowkhamba Sanskrit Series Office.

Jaiminìya Upanișad Brāhmaṇa

Oertel, H. 1896. The Jāiminīya or Talavakāra Upanișad Brāhmaṇa. Journal of the American Oriental Society, 16, 79-260. DOI: https://doi.org/10.2307/592488

Dharmaputrikā

(See references to manuscripts in footnote 6.)

Apograph of the Śivadharma corpus from the Wellcome Library. Copied in 1912 or 1913? Paper, 409 folios. Contents (with the correction of some wrong folios and the order of two texts wrongly inverted in the references as given by De Simini 2016a: 276): Śivadharmaśāstra (serial no. 634), fols. 1v-63r; Śivadharmottara (serial no. 635), fols. 64r-143v; Śivadharmasamgraha (serial no. 633), fols. 144r-217v; Umāmaheśvarasamvāda (serial no. 652), fols. 218v-263v; Uttarottaramahāsamvāda (serial no. 654) fols. 264r-297v; Śivopanișad (serial no. 636), fols. 298r-325v; Vrșasārasamgraha (serial no. 657), fols. 326r-392v; Dharmaputrikā (serial no. 608), fols. 393r-409r.

Yogin Naraharinātha (ed.). 1998 (saṃvat 2055). Śivadharma Paśupatinam Śivadharmamahāśāstram Paśupatināthadarśanam. Kathmandu.

Niśvāsatattvasamhitā

Goodall, D. (ed., transl.). 2015. The Niśvāsatattvasaṃhitā.: The Earliest Surviving Śaiva Tantra. Volume 1. A Critical Edition \& Annotated Translation of the Mūlasūtra, Uttarasūtra \& Nayasūtra. Pondicherry: Institut français de Pondichéry, Ecole française d'ExtrêmeOrient, Asien-Africa-Institut Universität Hamburg.

Niśvāsamukha

Kafle, N. 2015. Doctorate thesis. The Niśvāsamukha, the introductory book of the Niśvāsatattvasaṃhitā: critical edition, with an introduction and annotated translation appended by Śivadharmasangraha 5-9. Leiden University. 


\section{JOURNAL OF \\ YOGA STUDIES}

2020 - Volume 3

Nāṭyaśāstra

Shastri, M. 1981. Nātyashāstra of Bharatmuni. Part Third. Abhinavbharati of Acharya Abhinav Gupta. Edited with an Original Profound Introduction Commentaries by Acharya Shri Madhusudan Shastri. Varanasi: Banaras Hindu University.

Pātañjalayogaśāstra (PYŚ)

Āgāśe, K. Ś. (ed.). 1904. Vācaspatimiśraviracitațīkāsaṃvalita-Vyāsabhāṣyasametāni Pātanjalayogasūtrāṇi, tathā Bhojadevaviracita-Rājamārtaṇ̂̄ābhidhavrttisametāni Pātanjalayogasūtrāṇi <Sūtrapāṭhasūtravarṇānukramasūcībhyāṃ ca sanāthīkrtāni, > ... tac ca H. N. Āpațe ity anena ... prakāśitam. Punyākhyapattana [= Pune] 1904 (Ānandāśramasaṃskṛtagranthāvaliḥ 47).

Maas, P. A. 2006. Samādhipāda. Das erste Kapitel des Pātanjalayogaśāstra zum ersten Mal kritisch ediert / The First Chapter of the Pātañjalayogaśāstra for the First Time Critically Edited. Aachen: Shaker (Studia Indologica Universitatis Halensis) (Geisteskultur Indiens. Texte und Studien 9).

Woods, J. H. (transl.). 1914. The Yoga-System of Patañjali: or the Ancient Hindu Doctrine of Concentration of Mind, Embracing the Mnemonic Rules, Called Yoga-Sütras, of Patañjali and the Comment, Called Yoga-Bhāshya, Attributed to Veda-Vyāsa, and the Explanation, Called Tattva-Vaiçāradī, of Vāchaspati-Miçra. Translated from the original Sanskrit by James Haughton Woods. Cambridge: Harvard University Press (Harvard Oriental Series 17). Reprint, Delhi: Motilal Banarsidass 1998.

Pātañjalayogasūtrabhāṣyavivaraṇa

Harimoto, K. 2014. God, Reason, and Yoga: A Critical Edition and Translation of the Commentary Ascribed to Sañkara on Pātañjalayogaśāstra 1.23-28. Hamburg: Department of Indian and Tibetan Studies, Universität Hamburg.

Rukmani, T. S. 2001. Yogasūtrabhāṣyavivarana of Śañkara. Vivarana text with English translation and critical notes along with text and English translation of Patañjali's Yogasūtras and Vyāsabhāsya. Volume 1, Samādhipādah and Sādhanapādah, Volume 2, Vibhūtipādah and Kaivalyapādah. Munshiram Manoharlal, New Delhi.

Leggett, T. 1992 (1990). The complete commentary by Śankara on the Yoga Sütra-s: a full translation of the newly discovered text. Delhi: Motilal Banarsidass

Śāstrī, P. S. R. and Śāstrī, S. R. K. (ed.). 1952. Pātañjala-yogasūtra-bhāṣya-vivaraṇam of Śankkara-bhagavatpāda. Madras Government Oriental Series 94. Government Oriental Manuscripts Library, Madras. 


\section{JOURNAL OF \\ YOGA STUDIES}

2020 - Volume 3

Pāśupatasūtrabhāṣya

Shastri, R. A. (ed.). 1940. Pāśupatasūtras, with Kaundinya's Pancārthabhasya.

Trivandrum: The Oriental Manuscripts Library of the University of Travancore

(Trivandrum Sanskrit Series, 143).

Brahmasūtra

Śāstrī, N. S. A. and Pansíikar, V. L. Ś. (eds.). 1917. Brahmasūtraśānikarabhāsyam, ŚrīmadAppayyadīkșita-viracita-Parimalopabrṃhita-Śrimad-Amalānandasarasvatī-praṇitaKalpataruvyākhyāyuta-Śrīmad-Vācaspatimiśrakrta-Bhāmatīvilasitam. Nirnaya Sagar Press, Bombay.

Bshad mdzod yid bzhin nor bu (of Don dam smra ba'i sen ge)

Chandra, L. (ed.). 1969. A 15th Century Tibetan Compendium of Knowledge. The Bśad mdzod yid-bzhin nor bu by Don-dam-smra-ba'i-senge. With an introduction by $\mathrm{E}$. Gene Smith. New Delhi: International Academy of Indian Culture.

Bhāgavadgītābhāṣya (of Śañkara)

Āgāśe, K. (ed.). 1897. Śrīmadbhagavadgìtā

Ānandagiriviracitațīkāsaṃvalitāsāànkarabhāṣyasametā [...].

Ānandāśramasaṃskṛtagranthāvaliḥ 34, Poona: Ānandāśrama Press.

Matangapārameśvaratantra

Bhatt, N. R. (ed.). 1977. Matañgapārameśvarāgama (Vidyāpāda) : avec le commentaire de Bhațta Rāmakaṇțha. Edition critique par N. R. Bhatt. Pondichéry : Institut français d'indologie (PIFI : collection Indologie, 56).

- 1982. Matañgapārameśvarāgama (Kriyāpāda, Yogapāda et Caryāpāda) : avec le commentaire de Bhaț̣a Rāmakaṇtha. Edition critique par N. R. Bhatt.

Pondichéry : Institut français d'indologie (PIFI : collection Indologie, 65).

Mahābhārata

Sukthankar, V. S., Belvalkar, S. K., and Vaidya, P. L. (eds.). 1933-66. The Mahābhārata for the first time critically edited. 19 vol. Ed. by Vishnu S. Sukthankar, S. K. Belvalkar, and P. L. Vaidya. Poona: Bhandarkar Oriental Research Institute.

Mahāsatipațțhāna-Sutta

Rhys Davids, T. W. (transl.). 1910. "Mahāsatipațthāna Suttanta: Setting-up of Mindfulness." In Dialogues of the Buddha. Vol. 2. Translated from the Pāli of the Digha Nikāya, edited by T. W. Rhys Davids. London: Henry Frowde, Oxford University Press, 327-346.

Rhys Davids, T. W. and Carpenter, J. E. (eds.). 1890-1911. The Dīgha Nikāya. 3 vols. London: Pali Text Society. 


\section{JOURNAL OF \\ YOGA STUDIES}

2020 - Volume 3

Mānavadharmaśāstra

Olivelle, P. (ed., transl., with Suman Olivelle). 2006. Manu's Code of Law: A critical edition and translation of the Mānava-dharmaśāstra. New Delhi: Oxford University Press.

Mālinīvijayottaratantra

Vasudeva, S. (ed., transl., and notes). 2004. The Yoga of the Mālinivijayottaratantra: chapters 1-4, 7, 11-17. Pondichéry: Institut français de Pondichéry; EFEO (PIFI: collection Indologie, 97).

Mārkaṇḍeyapurāṇa

Banerjea, K. M. (ed.). 1862. The Marcandeya Purana in the Original Sanskrit. Calcutta: Bishop's College Press.

Muṇ̣aka Upaniṣad

Maury, J. (ed., transl.). 1943. Mundaka Upanișad. Paris: Adrien-Maisonneuve.

Radhakrishnan, S. (intro., ed., transl., and notes). 1992 (1953). "Muṇạa Upanișad." In The Principal Upanișads. 5th print. Delhi, Bombay, Calcutta: Oxford University Press.

Maitrāyaṇīya Upaniṣad

van Buitenen, J. A. B. 1962. The Maitrāyanīya Upanișad. A Critical Essay, with Text, Translation and Commentary. The Hague: Mouton \& Co.

Mṛgendrāgama

Śrimrgendraṃ Kāmikopāgamam (vidyāpāda and yogapāda; ed. with the vrttti of Nārāyanakaṇtha and the dīikikā of Aghoraśivācārya). Śivāgama (siddhāntaparipālana) sangha 12. Dêvakôtțai, 1928.

Śāstrī, M. K. (ed., preface, and intro.). 1930. Mrgendra Tantram, Vidyāpāda and Yogapāda: with commentary of Bhațta Nārāyanakanțha. Srinagar: Research dep.; Bombay: Nirnaya Sagar Press (Kashmir series of texts and studies, 50).

Hulin, M. (transl., intro. and notes). 1980. Mrgendrāgama: section de la doctrine et du yoga: avec la vrttti de Bhațtanārāyaṇakanțha et la dīpikā d'Aghoraśivācārya. Pondichéry: Institut français d'indologie (PIFI, collection Indologie, 63).

Yuktidīpikā

Wezler, A. and Shujun, M. (eds.). 1998. Yuktidīpikā: the most significant commentary on the Sāṃkhyakārikā. Vol. I. (Alt und Neu-Indische Studien, 44.). Stuttgart: Franz Steiner Verlag. 


\section{JOURNAL OF \\ YOGA STUDIES}

$2020 \cdot$ Volume 3

Yogacintāmaṇi (of Śivānandasarasvatī)

Śarma, H. (ed.). 1927. Yogacintāmanih [of Śivānandasarasvatī]. Calcutta: Oriental Press.

Yogavārtika (of Vijñānabhikșu)

Pātañjalayogadarśanam, vācaspatimiśraviracita-tattvavaiśāradi-vijñānabhikșukrtayogavārtika-vibhūṣita-vyāsabhāṣyasametam. 1971. Vārāṇasī: Bhāratīya Vidyā Prakāśana.

Yogaśāstra (of Hemacandra)

Qvarnström, O. 2012. A Handbook on the Three Jewels of Jainism: The Yogaśāstra of Hemacandra. Pandit Nathuram Premi Research Series, Volume 29. Mumbai: Hindi Granth Karyalay.

Yogasiddhāntacandrikā, Nārāyaṇatīrtha

Bhatta, P. R. G. (ed.). 1910. Yogadarçanam with a Commentary Called the Yogasiddhāntacandrikā of Nārāyanatīrtha. Varanasi: Vidya Vilasa Press.

Vāyavīyasaṃhitā

Barois, C. 2012. Doctoral thesis. Volume I: présentation de la Vāyavīyasaṃhitā (manuscripts, histoire textuelle, structure, sources). Volume II: traduction annotée du Pūrvabhāga (30 chapitres) et résumés détaillés de l'Uttarabhāga (30 chapitres également). Volume III: texte révisé de la Vāyaviyasaṃhitā, établi à partir des éditions de Calcutta (1890) et de Bénarès $(1963,1998)$, représentatives de deux recensions du Śivapurāna. Paris: École pratique des hautes études.

Vāyupurāṇa

Caturvedī, V. and Simha, N. (eds.). 1995 (1983). The Vāyumahāpurānam: with preface, verse-index and textual corrections. 2nd ed. Delhi: Nag Publishers [Reprint of the Bombay edition: Śrīveñkateșvara-Sțìm Mudraṇayantrālaya, 1933 or 1934].

Viṣnudharmāh

Grünendahl, R. (ed.). 1983, 1984, and 1989. Vișnudharmāh. Precepts for the Worship of Viṣnu. Part 1: Adhyāyas 1-43 (1983); Part 2: Adhyāyas 44-81 (1984); Part 3: Adhyāyas 82-105 (1989)(with a Pāda-index of Adhyāyas 1-105). Wiesbaden: Harrassowitz.

Vīṇāśikhatantra

Goudriaan, T. (ed., intro., and transl.). 1985. Vin̄āśikhatantra: A Śaiva Tantra of the Left Current. Delhi: Motilal Banarsidass.

Lingapurāṇa

Shastri, J. L. (ed.). 1980. Linga Purāna = Lingapurānam: with the Sanskrit commentary Śivatoșini of Gaṇeśa Nātu. Delhi: Motilal Banarsidass. 
Śānkhāyanāraṇyaka

Dev, B. (ed.). 1980. Śānkhāyanāranyaka. (Vishveshvaranand Indological Series, 70), Hoshiarpur: Vishveshvaranand Vedic Research Institute.

Śivadharmaśāstra

$\rightarrow$ See Dharmaputrikā.

Śivadharmottara

$\rightarrow$ See Dharmaputrikā.

Śivasūtra

Singh, J. (transl., intro., and notes). 1979. Śiva Sūtras: the yoga of supreme identity; text of the Sūtras and the commentary Vimarśini of Ksemarāja. Delhi: Motilal Banarsidass.

Śvetāśvatara Upaniṣad

Mahadeva Sastri, A. (ed.). 1988 (1925). Śvetāśvatara Upanișad. In The Śaiva Upanișad-s, with the commentary of Śri Upanișad-Brahma-Yogi. Madras: The Adyar Library and Research Centre (Adyar Library series; 9). Reprint, 1988.

Silburn, A. (ed., transl.). 1948. Śvetāśvatara Upaniṣad. Paris: Adrien-Maisonneuve (Les Upanishad: texte et traduction sous la direction de Louis Renou, 7).

Radhakrishnan, S. (ed., intro., transl. and notes), 1992 (1953). Śvetāśvatara Upanișad. In The Principal Upanișads. 5th print. Delhi, Bombay, Calcutta: Oxford University Press.

Sarvajñānottaratantra

Vaidyanathan, U. 1993. Sarvajñannottara: A Critical Edition and Study. A thesis submitted to the Pondicherry University for the Degree of Doctor of Philosophy. Department of Sanskrit, Pondicherry University, April 1993.

Sāṃkhyakārikā and commentaries

Śarmā, V. P. (ed.). 1970. Sāṃkhya-kārikā of śrimmad İśvarakrșna: with the Māṭharavrtti of Māțharācārya and the Jayamanigalā of śri Śankara. Varanasi: The Chowkhamba Sanskrit Series Office (Chowkhamba Sanskrit Series, 296 [Work nº 56]).

Suśrutāsaṃhitā

Trikamji Ācārya, J. (ed.). 1931. The Sushritâsamhitâ of Sushruta, with the Nibandhsangraha Commentary of Shree Dalhañāchārya (vaidyavaraśrīdalhaṇācāryaviracitayā nibandhasaṃgrahākhyavyākhyayā samullasitā maharșinā suśrutena viracitā suśrutasaṃhitā, sūtra-nidāna-śārīra-cikitsākalpasthānottaratantrātmakah). Edited by Vaidya Jâdavaji Trikamji Âchârya. Revised 2nd ed. Bombay: Nirṇaya Sāgar Press. 


\section{JOURNAL OF \\ YOGA STUDIES}

2020 - Volume 3

-1939. Suśrutasaṃhitāyāḥ sūtrasthānam. śrīcakrapāṇidattaviracitayā

bhānumatīvyākhyayā sametam = Suśruta-samitā (Sūtrasthāna): with Bhānumatī commentary by Cakrapānidatta, with introd. by Kaviraj Gananatha Sen Saraswati. Ed. by Vaidya Yādavaji Trikamji and Nandakishor Sharma Bhishagacharya. Agra: Śyāmasundara Śarman.

Sharma, P. V. (text and transl.). 1999-2001. Śuśruta-Samhitā, with English translation of text and Dalhana's commentary along with critical notes, 3 vols. Haridas Ayurveda Series 9. Varanasi: Chaukhambha Visvabharat.

Somaśambhupaddhati

Brunner-Lachaux, H. (ed., transl., and notes). 1963. Somaśambhupaddhati. Première partie, le rituel quotidien dans la tradition śivaïte de l'Inde du Sud selon Somaśambhu. Pondichéry: Institut français d'indologie (PIFI, collection Indologie, 25.1).

Brunner-Lachaux, H. (ed., transl. and notes). 1977. Somaśambhupaddhati. Troisième partie, rituels occasionels dans la tradition śivaïte de l'Inde du Sud selon Somaśambhu, II : dìkșā, abhișeka, vratoddhāra, antyeștii, śrāddha. Pondichéry: Institut français d'indologie (PIFI, collection Indologie, 25.3).

Skandapurāṇa

Bhatțarāī, K. 1988. Skandapurānasya Ambikākhaṇdah. Kathmandu:

Mahendrasaṃskṛtaviśvavidyālaya.

Hațhapradīpikā

Swami Digambaraji and Raghunathashastri K. (eds.). 1998. Hathapradīpikā of Svātmārāma. 2nd ed. Lonavla: Swami Digambaraji for the Kaivalyadhama, S. M. Y. M. Samiti. URL: https://goo.gl/Tgzr1o. Accessed on: January 3, 2018.

\section{Secondary Sources}

Barois, C. 2019. "Le maître dans la tradition śivaïte de l'Inde du Sud. Lecture de la Vāyavìyasaṃhitā II 13." In L’Image du maître spirituel, Ed. François Raviez, 59-81. Arras: Artois Presses Université.

-2021 (forthcoming). '“Cette âme tombée dans un corps étranger.' Notes introductives au Bhāgavatapurāna III 31." In Embryon, personne et parenté, Eds. Enric Porqueres I Gené et Séverine Mathieu. Paris: Maison des Sciences de l'Homme.

Beckwith, C. I. 1979. "The Introduction of Greek Medicine into Tibet in the Seventh and Eight Centuries." Journal of the American Oriental Society, 99 (2): 297-313.

Birch, J. 2013. "Räjayoga: The Reincarnations of the King of all Yogas." International Journal of Hindu Studies, 17(3): 401-44. 


\section{JOURNAL OF \\ YOGA STUDIES}

2020 - Volume 3

-2018 (2013). “The Proliferation of Āsana-s in Late Mediaeval Yoga Texts." In Yoga in Transformation: Historical and Contemporary Perspectives, Eds. Karl Baier, Philipp A. Maas, and Karin Preisendanz, 101-79. Göttingen: V\&R Unipress (Vienna University Press).

Birch, J. and Singleton, M. 2021 (forthcoming). The Wish-Fulfilling Gem of Yoga. The Āsana of the Yogacintāmani.

Bisschop, P. C. 2010. "Once Again on the Identity of Candeśvara in Early Śaivism: A Rare Candeśvara in the British Museum?" Indo-Iranian Journal, 53: 233-49.

-2014. "Invoking the Powers that Be: The Śivadharma's Mahāśānti Mantra." South Asian Studies, 30 (2): 133-41.

-2018. Universal Śaivism. The Appeasement of All Gods and Powers in the Śāntyadhyāya of the Śivadharmaśāstra. Boston, USA: Brill. DOI: https://doi.org/10.1163/9789004384361

Bronkhorst, J. 1993. The Two Traditions of Meditation in Ancient India. Delhi: Motilal Banarsidass, 1993 (Reprint: 2000). [1st ed.: Stuttgart: Franz Steiner Verlag Wiesbaden $\mathrm{GmbH}, 1986]$.

Brunner, H. 1974. “Un tantra du Nord : le Netratantra.” Bulletin de l'Ecole française d'Extrême-Orient, tome LXI, 1974: 125-97.

De Simini, F. 2016a."Śivadharma Manuscripts from Nepal and the Making of a Śaiva Corpus." In One Volume-Libraries: Composite and Multiple-text Manuscripts, Eds. Michael Friedrich and Cosima Schwarke, 233-86. Berlin, Boston: De Gruyter.

-2016b. Of Gods and Books. Ritual and Knowledge Transmission in the Manuscript Cultures of Premodern India. Berlin, Boston: De Gruyter.

-2017. "When Lachmann's Method Meets the Dharma of Śiva. Common Errors, Scribal Interventions, and the Transmission of the Śivadharma Corpus." In Indic Manuscript Cultures through the Ages, Ed. by Daniele Cuneo, Camillo Alessio Formigatti, and Vincenzo Vergiani, 505-48. Berlin, Boston: De Gruyter.

De Simini, F. and Mirnig, N. 2017. “Umā and Śiva’s Playful Talks in Detail (Lalitavistara): On the Production of Śaiva Works and their Manuscripts in Medieval Nepal. Studies on the Śivadharma and the Mahäbhärata 1." In Indic Manuscript Cultures through the Ages, Ed. by Daniele Cuneo, Camillo Alessio Formigatti, and Vincenzo Vergiani, 587654. Berlin, Boston: De Gruyter.

Dotson, B. 2009. The Old Tibetan Annals. An Annotated Translation of Tibet's First History. With an Annotated Cartographical Documentation by Guntram Hazod. Wien: Österreichische Akademie der Wissenschaften.

Einoo, S. 2005. “The Formation of Hindu Ritual." In From Material to Deity: Indian Rituals of Consecration, Eds. Shingo Einoo and Jun Takashima, 7-49. Delhi: Manohar. 


\section{JOURNAL OF

Endo, K. 1993. "The Works and Flourishing Period of Nārāyaṇa Tīrtha, the Author of the Yogasiddhāntacandrikā." Nagoya Studies in Indian Culture and Buddhism, 14: 41-60.

Frauwallner, E. 1953. Geschichte der indischen philosophie, I. Band: Die Philosophie des Veda und des Epos; Der Buddha und der Jina; Das Sāṃkhya und das klassische Yoga-System. Salzburg: Otto Müller Verlag.

Garrett, F. 2007. “Critical Methods in Tibetan Medical Histories." Journal of Asian Studies, 66(2): 363-87.

Gode, P. K. 1953. Studies in Indian Literary History. Vol. 1. Bombay: Singhi Jain Śāstra Śikshāpīth Bhāratīya Vidyā Bhavan.

Goodall, D. 2011. “The Throne of Worship: An 'Archeological Tell' of religious rivalries.” Studies in History, 27(2): 221-50.

-2016. "How the Tattvas of Tantric Śaivism Came to Be 36: The Evidence of the Niśvāsatattvasaṃhitā." In Tantric Studies. Fruits of a Franco-German Collaboration on Early Tantra, Eds. Dominic Goodall and Harunaga Isaacson, 131.4, 77-111. Institut français de Pondichéry, Ecole française d'Extrême-Orient.

Goodall, D. and Harunaga I. 2016. “On the Shared 'Ritual Syntax' of the Early Tantric Traditions." In Tantric Studies. Fruits of a Franco-German Collaboration on Early Tantra, Eds. Dominic Goodall and Harunaga Isaacson, 131.4: 1-76. Institut français de Pondichéry/Ecole française d'Extrême-Orient.

Hazra, R. C. 1983. “The Śiva-dharmottara," Purāna 27.1, 181-210 (reprint of "The Śivadharmottara," Journal of the Ganganatha Jha Research Institute, vol. 13, 1955-56: 1950).

-1985. "The Śivadharma," Purāna 27.1, 282-99 (reprint of “The Śivadharma," Journal of the Ganganatha Jha Research Institute, 10 (1952-53): 1-20).

Heiligers-Seelen, D. 1994. The System of Five Cakras in Kubjikāmatatantra 14-16. Groningen Oriental Studies 9. Groningen: Egbert Forsten.

Hellwig, O. 2010-19. DCS - Digital Corpus of Sanskrit. URL: http:/ / www.sanskritlinguistics.org/dcs/index.php.

Kane, P. V. 1930-72. History of Dharmaśāstra, 5 vols. Poona: Bhandarkar Oriental Research Institute.

Kritzer, R. 2014. Garbhāvakrāntisūtra: The Sūtra on Entry into the Womb, Studia Philologica Buddhica Monograph Series 31. Tokyo: International Institute for Buddhist Studies. -2017. “Aśubhabhāvanā in Vibhāṣā and Śrāvakabhūmi." In Śrāvakabhūmi and Buddhist Manuscripts, Eds. Seongcheol and Jundo Nagashima, 27-60. Tokyo: Nombre. 


\section{JOURNAL OF \\ YOGA STUDIES}

2020 - Volume 3

Kunjunni Raja, K. (ed.). 1977. New Catalogus Catalogorum. An alphabetical register of Sanskrit and allied works and authors. Dā-Na, Vol. 9. Madras: University of Madras, Sanskrit Department.

Lubin, T. 2016. "Baudhāyanīya Contributions to Smārta Hinduism." In Vedic Sākhās: Past, Present, Future. Proceedings of the Fifth International Vedic Workshop, Bucharest 2011, Eds. Jan E.M. Houben, Julieta Rotaru, and Michael Witzel, 591-606. Harvard Oriental Studies, Opera Minora 9. Cambridge, Mass.: Harvard University.

Maas, P. A. 2013. "A Concise Historiography of Classical Yoga Philosophy.” In Periodization and Historiography of Indian Philosophy, Ed. Eli Franco, 53-90. Publications of the De Nobili Research Library, 37. Vienna: Sammlung De Nobili.

-2014. “Der Yogi und sein Heilsweg im Yoga des Patanjali." In Wege zum Heil(igen): Sakralität und Sakralisierung in hinduistischen Traditionen? Ed. Karin Steiner, 65-90. Wiesbaden: Harrassowitz.

Malinar, A. 2007. The Bhagavadgitā: Doctrines and Contexts. Cambridge: Cambridge University Press.

-2012. "Yoga Practices in the Bhagavadgitā." In Yoga in Practice, Ed. David. G. White, 5872. Princeton: Princeton University Press.

-2014. "Following one's Desire (kāmacāra): On a Characterisation of Freedom in Vedic Literature and the Mahābhārata." Asiatische Studien/Études Asiatiques, 68 (4): 757-82.

Mallinson, J. 2014. "The Yogīs' Latest Trick." Journal of the Royal Asiatic Society 24(1): 16580.

Mallinson, J. and Singleton, M. 2017. Roots of Yoga. Translated and Edited with an Introduction. London: Penguin Classics.

Martin, D. 2007. “An Early Tibetan History of Indian Medicine." In Soundings in Tibetan Medicine: Anthropological and Historical Perspectives, Ed. Mona Schremp, 307-25. Leiden: Brill.

-2011. “Greek and Islamic Medicines' Historical Contact with Tibet: A Reassessment in View of Recently Available but Relatively Early Sources on Tibetan Medical Eclecticism." In Islam and Tibet: Interactions along the Musk Routes, Eds. Anna Akasoy, Charles Burnett, and Ronit Yoeli-Tlali, 117-43. Farnham: Ashgate.

Meulenbeld, G. J. 1999-2002. A History of Indian Medical Literature, Groningen Oriental Studies 15, 5 vols. Groningen: Egbert Forsten.

Mitra, A. 1989. Origin and Development Of Sanskrit Metrics. Calcutta: The Asiatic Society. Nakamura, H. 1983. A History of Early Vedānta Philosophy. Delhi: Motilal Banarsidass. 


\section{JOURNAL OF \\ YOGA STUDIES}

2020 - Volume 3

Padoux, A. 1987. “Contributions à l'étude du Mantraśāstra: III. Le Japa.” Bulletin de l'Ecole française d'Extrême-Orient, tome 76, 1987: 117-64. DOI: https://doi.org/10.3406/befeo. 1987.1719

Petech, L. 1984. Mediaeval History of Nepal (c. 750-1482). Serie Orientale Roma LIV. Roma: Istituto Italiano per il Medio ed Estremo Oriente (Is.Me.O), first edition: 1958.

Rastelli, M. and Goodall, D. (eds.). 2013. Tāntrikābhidhānakośa III, T-Ph: Dictionnaire des termes techniques de la littérature hindoue tantrique. A Dictionary of Technical Terms from Hindu Tantric Literature. Wörterbuch zur Terminologie hinduistischer Tantren. (Beiträge zur Kultur- und Geistesgeschichte Asiens 76.) Wien: Verlag der Österreichischen Akademie der Wissenschaften.

Salomon, R. 1981. "A Linguistic Analysis of the Mundaka Upanișad." Wiener Zeitschrift für die Kunde Südasiens, 25: 91-105.

Sanderson, A. 2012. Śaivism and Brahmanism. Handout 5, 22 February. Handouts for lectures, February to March 2012 (All Souls College, Oxford). URL: https:// oxford.academia.edu/AlexisSanderson. Accessed on: December 13, 2020.

Schreiner, P. 1988. “Yoga - Lebenshilfe oder Sterbetechnik?” Umwelt \& Gesundheit, Heft 3/4, Köln, 12-18.

Sferra, F. (ed. and transl.). 2000. The Șadangayoga by Anupamarakșita: with Raviśrïjñāna's Gunabharanināmașadangayogațippaṇi. Text and annotated translation. Roma: Istituto Italiano per l'Africa e l'Oriente.

-2006. The Sekoddeśațīkā by Nāropā: (Paramārthasamgraha). Critical edition of the Sanskrit text by Francesco Sferra; critical edition of the Tibetan translation by Stefania Merzagora. Roma: Istituto Italiano per l'Africa e l'Oriente.

Sparham, G. 1987. "Background Material for the First of the Seventy Topics in Maitreyanātha's Abhisamayālaṃkāra." The Journal of the International Association of Buddhist Studies, 10.2: 139-58.

-1992. "Indian Altruism: A Study of the Terms bodhicitta and bodhicittotpāda," The Journal of the International Association of Buddhist Studies 15(2): 224-42.

Törzsök, J. 2004. "Three Chapters of Śaiva Material Added to the Earliest Known Recension of the Skandapurāna." In Origin and Growth of the Purānic Text Corpus With Special Reference to the Skandapurāna, Papers of the 12th World Sanskrit Conference, vol. 3.2. Ed. Hans T. Bakker, 17-39. Delhi: Motilal Banarsidass.

Velankar, H. D. 1928. A Descriptive Catalogue of Sanskrta and Prakrta Manuscripts in the Library of the Bombay Branch of the Royal Asiatic Society, vol. 2: Hindu Literature. Bombay: BBRA 1928. 


\section{JOURNAL OF

Wijayaratna, M. 1990. Buddhist Monastic Life According to the Texts of the Theravāda Tradition. Cambridge: Cambridge University Press.

Wujastyk, D. 1985. A Handlist of the Sanskrit and Prakrit Manuscripts in the Library of the Wellcome Institute for the History of Medicine, vol. 1. London: The Wellcome Institute for the History of Medicine.

-2012. "The path to Liberation through Yogic Mindfulness in Early Āyurveda." In Yoga in Practice, Ed. David G. White, 31-42. Princeton: Princeton University Press. 